\title{
Acceptance of Self-Driving Cars in United Arab Emirates
}

\author{
By Arwa A. Al Shamsi \\ The British University in Dubai
}

Abstract- Transportation industry witnessing a revolution of the emerging of self-driving cars which are autonomous vehicles that drive by itself without human involvement. It is expected that self-driving cars would have powerful feature and would provide a lot of benefits such as reducing traveling time, reducing traffic jams, reducing car accidents and many other benefits. The government of United Arab Emirates adopt technology implementation in all life aspects in the country starting by turning into smart government and then smart education and many other implementations of using technology in different aspects of the country. This adoption of technology positively affected UAE people's intention toward accepting technology. As UAE government always adopt best technology practices, it is expected that United Arab Emirates would adopt the using of autonomous cars. The aim of this research paper is to investigate UAE people's intention to turn into using self-driving cars. Researcher aim as well to explore the most common factors that may affect people's intention to turn into using self-driving cars. This research paper methodology based on quantitative methods for gathering data in which questionnaire developed and sent to people live in United Arab Emirates.

Keywords: self-driving car; autonomous; intention; features; specifications.

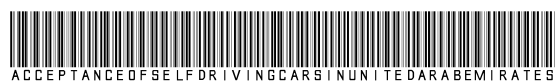

Strictly as per the compliance and regulations of:

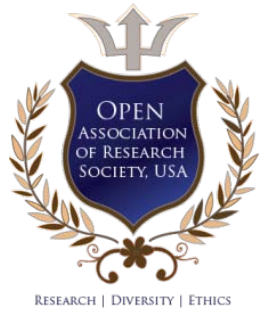

(c) 2020. Arwa A. Al Shamsi. This is a research/review paper, distributed under the terms of the Creative Commons AttributionNoncommercial 3.0 Unported License http://creativecommons.org/licenses/by-nc/3.0/), permitting all non-commercial use, distribution, and reproduction in any medium, provided the original work is properly cited. 


\title{
Acceptance of Self-Driving Cars in United Arab Emirates
}

\author{
Arwa A. Al Shamsi
}

\begin{abstract}
Transportation industry witnessing a revolution of the emerging of self-driving cars which are autonomous vehicles that drive by itself without human involvement. It is expected that self-driving cars would have powerful feature and would provide a lot of benefits such as reducing traveling time, reducing traffic jams, reducing car accidents and many other benefits. The government of United Arab Emirates adopt technology implementation in all life aspects in the country starting by turning into smart government and then smart education and many other implementations of using technology in different aspects of the country. This adoption of technology positively affected UAE people's intention toward accepting technology. As UAE government always adopt best technology practices, it is expected that United Arab Emirates would adopt the using of autonomous cars. The aim of this research paper is to investigate UAE people's intention to turn into using self-driving cars. Researcher aim as well to explore the most common factors that may affect people's intention to turn into using self-driving cars. This research paper methodology based on quantitative methods for gathering data in which questionnaire developed and sent to people live in United Arab Emirates. It was found that UAE people have great intention to turn into using self-driving cars. It was found as well that specifications and features of self-driving cars positively impacted people's decision to turn into using selfdriving car. It is recommended for further research to explore the infrastructure requirements in United Arab Emirates for the adoption of self-driving cars.
\end{abstract}

Keywords: self-driving car; autonomous; intention; features; specifications.

\section{InTRODUCTION}

A s technology development has taken on all aspects of life, the world of transportation is Iwitnessing a major revolution due to the emergence of self-driving cars. The emergence of selfdriving cars attracted the attention of the media as well as individuals in it. Brandon Schoettle and Michael Sivak, (2014) stated that the emergence of self-driving cars attracted people and researchers as well who aim to explore people's perception of self-driving car. Researchers as well aim to explore how reliable the selfdriving car is and what benefits the user may got when using this type of car. Self-driving car as defined by Daniel Howard and Danielle Dai, (2013) is an automated vehicle that has the ability to drive and move without human involvement. Self-driving car system is powerful, it is equipped as well with tools and resources that allow it to sense the world around it.

Author: The British University in Dubai. e-mails: arawe_a@yahoo.com, 20180935@student.buid.ac.ae
The adoption of self-driving cars may be necessary duo to many reasons related to regular transportation system and pollution as well. It is expected that self-driving cars would have great impact on transportation system by reducing car accidents, respecting road rules, reaching destinations fast and reducing traffic jams. Self-driving cars as well expected to reduce emissions which positively impacted environment. Old peoples and people who cannot drive may depend on self-driving cars for reaching their destinations as stated by Corey D.Harper, Chris T.Hendrickson, Sonia Mangones, Constantine Samaras, (2016). Even though self-driving cars expected to have lots of benefits and its features claimed to be extraordinary; it is essential to explore the people's intention to turn into using such car type.

The UAE is one of the best countries in the world in the adoption of technology in all aspects of life. UAE government is turned into smart government, the schools adopt smart learning methodologies and the UAE people rely on the use of technology in almost their daily transactions. It is expected that the United Arab Emirates would be one of the leading countries to adopt the usage of self-driving cars. Although the self-driving cars may provide huge benefits to the user compared to the traditional cars that the user drive, the people perception to turn into using this type of cars may vary as some users prefer to engage in driving by themselves.

The aim of this research paper is to investigate the UAE people's intention to turn into using self-driving cars. This investigation is important for UAE government to explore UAE people's acceptance toward using autonomous cars and to take steps for the adoption of such cars in the future such as setting up regulations and preparing infrastructure as well, for this transportation revolution.

This research applied quantitative methods for collecting data based upon utilization of questionnaire that was prepared and sent for respondents living in United Arab Emirates.

Study Design: the research organized starting by the first section which is the introduction of the research in which the researcher identified the topic as well as the purpose of the research. After that research problem statement identified in the second section. Third section is the research justification/theoretical background in which research papers discussed similar 
research topic were addressed and explored. The fourth section includes the research questions and related hypothesis that author aim to explore. The fifth section of the research defined the methodology utilized in this research paper. The sixth section includes the Data Analysis and statistical tests conducted in this research. The seventh section includes the research findings. The eighth sections include the discussion. Finally, conclusion included at the ninth section of the research paper.

\section{Research Problem Statement}

Recently, technology involved in all life aspects such as the emergence of self-driving car which considered as huge revolution in the industry of transportation. This revolution attracted researchers, individuals, companies and the media for different reasons either to explore the reliability of this type of cars as well as the people's perception of self-driving cars, or to investigate the intention of the people to turn into using this type of cars. Brandon Schoettle and Michael Sivak, (2014) stated that the revolution of selfdriving cars attracted many people and researchers as well. Self-driving car is an automated vehicle that has the ability to drive and move without human involvement as defined by Daniel Howard and Danielle Dai, (2013).Semi-automated cars are utilized widely while full-automated cars have been used in some countries as stated by Gora and Inga Rüba, (2016). The selfdriving cars that is considered in this research paper is the full-automated cars.

Traditional transportation result in many problems such as air pollution and traffic jams. Daniel Howard and Danielle Dai, (2013) explained how selfdriving cars are expected to reduce emissions, reduce traffic jams, reduce car accidents and allow users to reach their destinations fast. Corey D.Harper, Chris T.Hendrickson, Sonia Mangones, Constantine Samaras, (2016) as well showed how there is a need for selfdriving cars as people with disabilities, old peoples and people who cannot drive for any reason, could depend on self-driving cars for reaching their destinations.

Brandon Schoettle and Michael Sivak, (2015) mentioned that self-driving car would provide comfortability, safety and will reduce traffic jam as well. Michael A. Nees, (2016)believed that self-driving cars will give the users the chance to take benefits from road time. Ward C., Raue M., Lee C., D'Ambrosio L., Coughlin J.F, (2017) agreed on the mentioned benefits and added that self-driving cars will reduce traveling time and car accidents. Many research papers stated that self-driving cars expected to provide benefits for users.

The aim of this research paper is to explore the UAE people's intention to turn into using self-driving cars. The researcher aims to investigate the factors that affect people's decision to use self-driving cars. The researcher as well aim to examine the standard Technology Acceptance Model in case of introducing self-driving car for public.

The UAE is seeking the first position in all fields. One of the most important areas of interest to the Government of the United Arab Emirates is the technological field. The Government of the United Arab Emirates has become a smart government and technology is being applied in most of the life's aspects, which has established great acceptance to the transformation to technology among the people of the UAE. As the UAE continues to adopt international best practices in the field of technology, the revolution of using self-driving cars is expected to be supported by the Government of the United Arab Emirates. The adoption of self-driving cars requires investigating people's perception about this type of cars, it require as well exploring infrastructure requirements to adopt selfdriving cars, New road regulations must be set in order to adopt self-driving cars. But before taking any of the previously mentioned steps, it is essential to explore the UAE people's intention to turn into using self-driving car.

Existing researches deals mostly with people perception to autonomous cars, and some case studies conducted in in USA states and other countries to measure people's intention toward using autonomous cars. This research paper aim to fulfil the gap of measuring UAE people' intention to turn into using selfdriving car. The standard Technology Acceptance Model slightly modified by adding new constructs in order to measure the most common factors that affects UAE people's intention to turn into using self-driving cars.

The results from this investigation is important for the government of United Arab Emirates in order to explore UAE people's acceptance to turn into using autonomous cars and to take steps for autonomous cars adoption in the future such as setting up new road regulations and preparing infrastructure as well, for this transportation revolution.

\section{ili. Research Justification/ Theoretical Background}

\section{a) Autonomous self-driving car}

As technology development has taken on all aspects of life, we are witnessing a revolution in various means of transportation. One of the most important example of transportation revolution is the emergence of self-driving cars.Brandon Schoettle and Michael Sivak, (2014) stated that the emergence of self-driving cars gain the interest of many people as well as researchers who were interested in measuring the people's perception of such car. The Media as well was interested in self-driving car topic as it takes part of their reports and news. 
Daniel Howard and Danielle Dai, (2013) defined the self-driving car as an automated vehicle that has the ability to drive and move without human involvement. Self-driving car supplemented with resources that allow it to sense the world around it such as the radar and the GPS. Self-driving car equipped with powerful control system to control the movement of the car.

Daniel Howard and Danielle Dai, (2013) stated thatself-driving car history began with Achen Motor Company as it was the first company that brought up the idea of automation when it presented in Milwaukee a phantom motor car in early 1920 s.

The appearance of truly autonomous cars was in 1980s as mentioned by Pawel Gora and Inga Rüba, (2016), those emerged cars were less computerized as compared to autonomous cars nowadays. Later the automated car revolution has been emerged. In 2013 noticeable number of car companies became interested in self-driving cars such as Ford and Audi. Famous IT companies such as Google and Apple are doing their projects to introduce their own self-driving cars. Oxford University as well has developed models of self-driving cars.

Semi-automated cars are already been used widely while full-automated cars have been used in some countries for example in United States, in some states the use of self-driving cars is allowed such as Florida and California as mentioned by Gora and Inga Rüba, (2016).

National Highway Traffic Safety Administration NHTSA, (2013) introduced levels for automation classification that are ranged from 0 to 4 as explain below:

- 0: No Automation: Driver is completely responsible about driving.

- 1: Function-specific Automation: One or more of the control functions can be automated but they operated independently of each other and the driver is fully responsible about driving.

- 2: Combined Function Automation: Minimally two of the control functions can be automated and work together, and driver may have time to take hands and feet off the control.

- 3: Limited Self-Driving Automation: Automated car but the driver is expected to participate in driving when it is needed i.e. driving control will be shifted to the driver in some situations.

- 4: Full Self-Driving Automation: Driver will not participate in driving just will provide the destination.

b) The need for self-driving car

When considering the current transportation system, there are many problems that governments seek to find solutions for such as traffic congestion and air pollution resulting from the emissions of carbon dioxide from cars. one of the suggested solutions is the adoption of smart cars i.e. self-driving cars.
With the emergence of self-driving cars and people's interest in them, this important question comes to our minds, is there a need for this type of cars? There are many reasons to adopt the idea of self-driving cars. MatjažKnez, MatevžObrecht, (2019) stated that the car registration worldwide increased sharply year after year, and this increase directly affect the environment and raising the air pollution since most of these cars are fuelbased cars.Self-driving car is smart car some of these cars are fuel-based and some others are electric-based. The use of self-driving cars would give the users the opportunity to reach their destinations faster which may reduce the driving time hence reduce emissions. Daniel Howard and Danielle Dai, (2013) explained how selfdriving cars depends on Intelligent Transportation Systems (ITS) that provides high safety level and smart calculation for best road to reach destination. The use of smart transportation system will result in reducing traffic jams, reducing car accidents hence saving lives and reducing emissions hence reducing air pollution.

Corey D.Harper, Chris T.Hendrickson, Sonia Mangones, Constantine Samaras, (2016) stated that people with disabilities, old people as well as people that are not driving due to medical problems consider the self-driving car as a solution for them to reach their destinations hence there is an increase need for such cars. From what is mentioned earlier, it is clear that there is an increasing need for self-driving cars.

\section{c) Benefits of self-driving car}

Brandon Schoettle and Michael Sivak, (2015) believed that it is expected that the self-driving cars would provide great benefits to the users. It is expected that the self-driving cars will provide comfortability compared to traditional cars that the human drive which may result in increased of traveling and mobility. It is expected as well that the self-driving cars reduce traffic jams and provide high standards of safety. Michael A. Nees, (2016) stated as well that the self-driving cars would increase the safety and reduce traffic problems. Michael A. Nees, (2016) believed that self-driving cars would allow the users of the car to take benefits of the road time.

Ward C., Raue M., Lee C., D'Ambrosio L., Coughlin J.F, (2017) agrees on the benefits mentioned earlier that self-driving cars have great benefits such as reducing traveling time, reducing traffic jams, reducing car accidents and allowing the users to take benefits of the travelling time.

Yu Shi, Jiefeng Chen, Qi Li, (2017) studied how the use of self-driving cars effects the capacity of the traffic and found that the cooperation of self-driving cars will results in raising traffic capacity, researchers as well stated that self-driving cars are efficient is speeding up the traffic flows.

Self-driving cars would provide great transportation solution for people with disabilities, old 
people as well as people that are not driving due to medical problems as mentioned by Corey D.Harper, Chris T.Hendrickson, Sonia Mangones, Constantine Samaras, (2016).

When reviewing the benefits mentioned earlier, benefits of self-driving cars can be concluded as:

- Self-driving car expected to provide high safety as it respects road rules and will reduce the accidents that are due to human errors.

- The self-driving cars give the user the opportunity to take benefits of roads times.

- Self-driving car tends to provide comfort to the user of the car which can lead to increase in the travelling and mobility.

- $\quad$ Self-driving cars would have great impact on traffic system as it will reduce traffic jams and raise the traffic flows especially at peak-hours.

- Self-driving cars will reduce the transportation time as it will give the users the chance to reach destinations faster and as a result the fuel consumption will be reduced as well as the emissions from the cars will be reduced and that will have positive impacts on the environment.

- Self-driving car could be perfect transportation method especially for people with disabilities, old people and people that cannot drive due to medical problems.

\section{d) Challenges for self-driving car adoption}

Brandon Schoettle and Michael Sivak, (2014) mentioned how it is important to set new traffic regulations that consider self-driving cars. Michael $A$. Nees, (2016) raised an important challenge when start using self-driving cars as that type of cars may share the roads with traditional cars that the human drive and this may provide unexpected results.

Michael A. Nees, (2016) believed that the ideal prototype of the self-driving cars that has been advertised may not actually materialize when self-driving cars widely used in real world and this challenge may have negative impacts on public.

Daniel Howard and Danielle Dai, (2013)stated that despite that the self-driving cars planned to be more efficient and sustainable as well it is assumed that is would be a safe car, the perception of public to turn into using self-driving cars may be challenging as public concerned about the real safety and liability the selfdriving cars that will be provided in real world. Researchers as well mentioned the manufacturing cost as a challenge as it is expected that self-driving cars would be of high cost for users to own and for government to adapt the road infrastructure for the use of such cars.

M. König, L. Neumayr, (2016) raised the uncertainty challenge for the adoption of self-driving cars as researchers mentioned how people as well as stakeholders may resist to adopt such cars because of their opinions about car's uncertainty. Researchers as well mentioned the people's resistance to change and caution's to "new thing" as a big challenge for the adoption of self-driving cars. One more challenge raised by the researchers that some people drive for pleasure and racing purposes; those people may resist to turn into using self-driving cars.

Frank Douma and Sarah Aue Palodichuk, (2012) stated that self-driving cars may be target for hackers or terrorists. As self-driving cars route can be tracked easily; it is essential to consider the system security and privacy of the self-driving cars. People tend to care about their privacy hence securing the system of the self-driving cars is another challenge for the adoption of self-driving cars.

\section{Research Questions}

As been discussed in the previous sections, the research gab is to measure the people's intention to turn into using self-driving cars in United Arab Emirates. The objective of this research paper is to investigate the user's preferred specifications in self-driving cars and the relationship between self-driving car's features and the user's intention to turn into using self-driving car. The researcher as well aim to measure the difference between the male and females in their intention to turn into using self-driving car.

The emerge of self-driving cars attract0ed the interest of governments, car companies, researchers and people as well, surveys conducted in this field to report people's intention to use the self-driving cars.

The main research question to fulfil the gap is "To what extent people in United Arab Emirates have the intention to turn into using self-driving car?" This main research question will be addressed through the following research questions:

Q1: To what extent UAE people care about specifications of the self-driving car?

Q2: Does the specifications of the self-driving car impact the UAE people's intention to turn into using selfdriving car?

Q3: Does the self-driving car's features impact the UAE people's intention to turn into using self-driving car?

Q4: To what extent people in United Arab Emirates have the intention to turn into using self-driving car?

Q5: Does the Gender factor have different impact on the intention to turn into using self-driving car?

Q6: Does the Driving Experience factor have different impact on the intention to turn into using self-driving car?

Q7: Does the Education Level factor associated with the intention to turn into using self-driving car?

Q8: Does the Gender and Driving Experience associated?

This research aims to study the UAE people's intention to turn into using self-driving car and whether 
the self-driving car's features affect the user's decision and intention to use this type of cars. Thus, this research hypothesis that there is strong association between the self-driving car's features and people's intention to turn into using self-driving car. Author of this research paper stated the hypothesis of this research as following:

H1: UAE people highly care about the specification of self-driving car

H2: There is significant association between self-driving car's specifications and the UAE people's intention to turn into using self-driving car.

H3: There is significant association between self-driving car's features and the UAE people's intention to turn into using self-driving car.

H4: There is significant association between self-driving car's safety features and the UAE people's intention to turn into using self-driving car.

H5: There is significant association between self-driving car's performance features and the UAE people's intention to turn into using self-driving car.

H6: There is significant association between self-driving car's Ease of Use features and the UAE people's intention to turn into using self-driving car.

H7: There is significant association between self-driving car's Usefulness features and the UAE people's intention to turn into using self-driving car.

H8: there is no significant difference between males and females in their intention to turn into using self-driving car.

H9: Driving Experience have positive impact on the intention to turn into using self-driving car.

H10: Level of Education is not associated with the intention to turn into using self-driving car.

H11: there is significant association between gender and driving experience. questions:

Research hypothesis associated with research

Table 1: Research hypothesis associated with research questions

\begin{tabular}{|c|c|}
\hline Research Question & Related Hypothesis \\
\hline $\begin{array}{l}\text { Q1: To what extent UAE people care about specifications } \\
\text { of the self-driving car? }\end{array}$ & $\begin{array}{l}\text { H1: UAE people highly care about the specification of } \\
\text { self-driving car }\end{array}$ \\
\hline $\begin{array}{l}\text { Q2: Does the specifications of the self-driving car impact } \\
\text { the UAE people's intention to turn into using self-driving } \\
\text { car? }\end{array}$ & $\begin{array}{c}\text { H2: There is significant association between self-driving } \\
\text { car's specifications and the UAE people's intention to } \\
\text { turn into using self-driving car. }\end{array}$ \\
\hline \multirow{5}{*}{$\begin{array}{l}\text { Q3: Does the self-driving car's features impact the UAE } \\
\text { people's intention to turn into using self-driving car? }\end{array}$} & $\begin{array}{c}\text { H3: There is significant association between self-driving } \\
\text { car's features and the UAE people's intention to turn into } \\
\text { using self-driving car. }\end{array}$ \\
\hline & $\begin{array}{c}\text { H4: There is significant association between self-driving } \\
\text { car's safety features and the UAE people's intention to } \\
\text { turn into using self-driving car. }\end{array}$ \\
\hline & $\begin{array}{l}\text { H5: There is significant association between self-driving } \\
\text { car's performance features and the UAE people's } \\
\text { intention to turn into using self-driving car. }\end{array}$ \\
\hline & $\begin{array}{l}\text { H6: There is significant association between self-driving } \\
\text { car's Ease of Use features and the UAE people's } \\
\text { intention to turn into using self-driving car. }\end{array}$ \\
\hline & $\begin{array}{c}\text { H7: There is significant association between self-driving } \\
\text { car's Usefulness features and the UAE people's intention } \\
\text { to turn into using self-driving car. }\end{array}$ \\
\hline $\begin{array}{l}\text { Q4: To what extent people in United Arab Emirates have } \\
\text { the intention to turn into using self-driving car? }\end{array}$ & $\begin{array}{l}\text { H8: People in United Arab Emirates have great intention } \\
\text { to turn into using self-driving car. }\end{array}$ \\
\hline
\end{tabular}


Table 2: Research hypothesis associated with demographic questions:

\begin{tabular}{|c|c|}
\hline Demographic Questions & Related Hypothesis \\
\hline $\begin{array}{c}\text { Q5: Does the Gender factor have different impact on the } \\
\text { intention to turn into using self-driving car? }\end{array}$ & $\begin{array}{c}H 9 \text { : there is no significant difference between males and } \\
\text { females in their intention to turn into using self-driving } \\
\text { car. }\end{array}$ \\
\hline $\begin{array}{c}\text { Q6: Does the Driving Experience factor have different } \\
\text { impact on the intention to turn into using self-driving car? }\end{array}$ & $\begin{array}{c}H 10 \text { : Driving Experience have positive impact on the } \\
\text { intention to turn into using self-driving car. }\end{array}$ \\
$\begin{array}{c}\text { Q7: Does the Education Level factor associated with the } \\
\text { intention to turn into using self-driving car? }\end{array}$ & $H 11$ : Level of Education is not associated with the \\
intention to turn into using self-driving car.
\end{tabular}

The hypothesis above are tested utilizing bivariate correlation and Regression and other statistical tests. Sections below define the methodology and discuss the results found.

Technology Acceptance Model (TAM) utilized as basis for developing conceptual model for this research; Paul Legrisa, John Inghamb, Pierre Collerettec, (2003) stated that Technology Acceptance Model was introduced by Davis, (1989) in order to investigate users' reasons for accepting or rejecting technology, Figure 1 below illustrate Technology Acceptance Model (TAM).

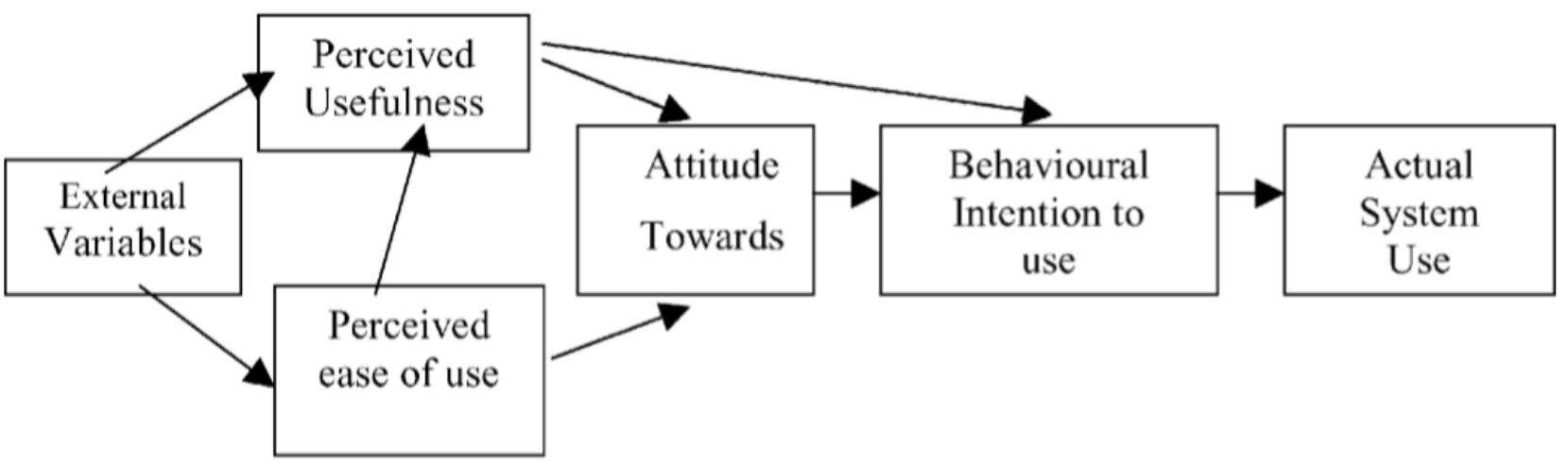

Figure 1: Original Technology Acceptance Model

For this research paper, Figure 2 illustrates research's conceptual Model. The intention to turn into using self-driving car model for this research paper developed based upon the basic Technology Acceptance Model. In this research paper, researcher identified two factors that affects user's intention to turn into using self-driving car i.e. specifications and features of self-driving car. Researcher aim to investigate whether the UAE people care about self-driving car specifications when intending to buy a car and to what extent they care about these specifications. Researcher identified the specifications as the information, facts and important details about the self-driving cars that most of the regular car companies displayed and proposed for the customers. These specifications are real and available in regular cars as well, such as: system, car outside look, wheels, braking system, engine, luxury and comfort, entertainment, number of passengers and seating. The second factor that is identified by the researcher and affect the intention to turn into using self- driving car is the features of the car. Researcher identified features based upon the Technology Acceptance Model as it consists of the Ease of Use features, Usefulness features and researcher added the safety and performance features as well, as presented by Figure 2 below. Self-driving features in this research paper represent the expected features in the self-driving car. 


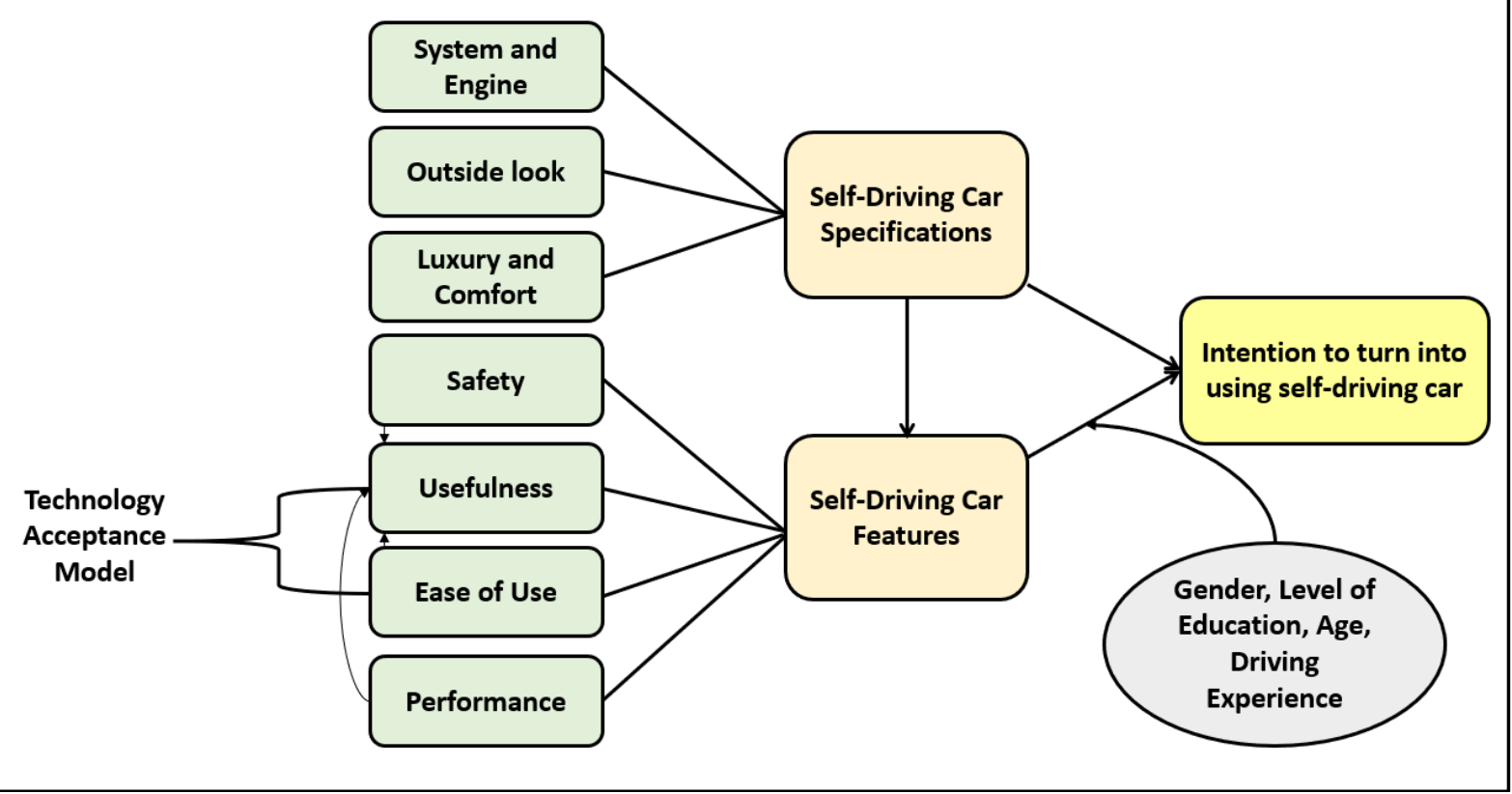

Figure 2: Research's conceptual framework

\section{Methodology}

Data utilized in this research paper is gathered through online questionnaire. Before start responding to the questionnaire, respondents must read brief description about the self-driving car. The questionnaire consists of four sections, the first section consists of five demographics i.e. age, gender, level of education, nationality and driving experience, the second section is to measure respondent's interest and care about the self-driving car's specifications, the third section is about self-driving car's features, and the forth section is to measure the respondent's intention to turn into using self-driving car. Questionnaire utilizes seven-point scales. The questionnaire is included in Appendix A.

The questionnaire was sent to number of respondents for testing and checking the accuracy of the questions as well as evaluating the clearness of the questions. The targeted population of the questionnaire is people in United Arab Emirates.

After testing the questionnaire, the questionnaire has been sent into 50 persons and the number of collected responses was 39 responds. Number of males participated in answering the questionnaire was 20 persons, while number of females was 19 persons. The age of the respondents to the questionnaire is up to 59 years old, nobody of 60 years old or above participated in answering the questionnaire. Questionnaire was sent to people of different education levels, but most of the responses were from people holding bachelor's degree. Information about driving experience as well collected from respondents to investigate if the driving experience has impact of respondent's decision to turn into using self-driving car.
Research hypothesis were investigated through statistical experiments in order to answer the three main research questions. Before conducting experiments, it is essential to identify the dependent and independent variables for each of the research questions as follows:

- For the first research question:

Q1: To what extent UAE people care about specifications of the self-driving car?

Dependent variables: user's interest in self-driving car's specification

Independent variables: Self-Driving car specifications (comfort, luxury, wheels and tires, braking-system, outside look, steering, number of passengers, seating, entertainment, safety system, multi-view technologies, car engine, speed, complete autonomous driving system, partial autonomous driving system)

Group: UAE people.

- For the second research question

Q2: Does the specifications of the self-driving car impact the UAE people's intention to turn into using self-driving car?

Dependent variable: user's intention to turn into using self-driving car

Independent variable: self-driving car specifications (comfort, luxury, wheels and tires, braking-system, outside look, steering, number of passengers, seating, entertainment, safety system, multi-view technologies, car engine, speed, complete autonomous driving system, partial autonomous driving system)

Group: UAE people. 
- $\quad$ For the third research question

Q3: Does the self-driving car's features impact the UAE people's intention to turn into using self-driving car?

Dependent variable: user's intention to turn into using self-driving car

Independent variable: self-driving car features (safety, performance, ease of use, benefits)

Group: UAE people.

- For the fourth research question:

Q4: To what extent people in United Arab Emirates have the intention to turn into using self-driving car?

Dependent variable: intention to turn into using selfdriving

Group: UAE people.

- For the fifth research question:

Q5: Does the Gender factor have different impact on the intention to turn into using self-driving car?

Dependent variable: intention to turn into using selfdriving

Group: Male and Female

- For the sixth research question:

Q6: Does the Driving Experience factor have different impact on the intention to turn into using self-driving car?

Dependent variable: intention to turn into using selfdriving

Group: UAE people with different Driving Experience

- For the seventh research question:

Q7: Does the Education Level factor associated with the intention to turn into using self-driving car?

Dependent variable: intention to turn into using selfdriving

Group: UAE people with different Education Level
The questionnaire questions uploaded into Google Forms to create online survey. Then the created survey was sent to the respondents. After gathering responses, file of responses was downloaded from Google Forms into SPSS software for analyzing results.

\section{Vi. Data Analysis (Statistical Tests)}

Responses were gathered and uploaded into SPSS software for data analysis purposes, number of statistical tests conducted as follows:

\section{a) Construct and scale validity}

It is essential to start with construct and scale validity test for the questionnaire. Haradhan Kumar MOHAJAN, (2017) stated that reliability and validity considered as essential and critical for questionnaire evaluation of good research paper. Validity is essential to indicate the finding's truthfulness, while reliability indicate how stable the findings are. The first test researcher started with is construct validity test then scale validity test. Sections below present results of construct and scale validity tests.

\section{i. Construct Validity}

Construct validity test conducted to measure whether the construct measured what it supposed to measure. Nigel Norris, (1997) stated that one method for measuring the validity is by checking the bias as human nature may result in some activity failings. Researchers as human may create some failings and mistakes. checking common bias can be used to indicate the validity. Below Table 3 present construct validity test by checking common bias.

Table 3: Construct Validity test to check common bias

\begin{tabular}{|c|c|c|c|c|c|c|c|c|c|}
\hline \multirow{2}{*}{ Component } & \multicolumn{3}{|c|}{ Initial Eigen values } & \multicolumn{3}{c|}{$\begin{array}{c}\text { Extraction Sums of Squared } \\
\text { Loadings }\end{array}$} & \multicolumn{3}{c|}{ Rotation Sums of Squared Loadings } \\
\cline { 2 - 10 } & Total & $\begin{array}{c}\text { \% of } \\
\text { Variance }\end{array}$ & $\begin{array}{c}\text { Cumulative } \\
\%\end{array}$ & Total & $\begin{array}{c}\text { \% of } \\
\text { Variance }\end{array}$ & $\begin{array}{c}\text { Cumulative } \\
\%\end{array}$ & Total & $\begin{array}{c}\% \text { of } \\
\text { Variance }\end{array}$ & $\begin{array}{c}\text { Cumulative } \\
\%\end{array}$ \\
\hline 1 & 15.719 & 40.306 & 40.306 & 15.719 & 40.306 & 40.306 & 10.354 & 26.550 & 26.550 \\
\hline 2 & 4.275 & 10.961 & 51.267 & 4.275 & 10.961 & 51.267 & 3.643 & 9.340 & 35.889 \\
\hline 3 & 2.649 & 6.793 & 58.059 & 2.649 & 6.793 & 58.059 & 3.572 & 9.159 & 45.049 \\
\hline 4 & 2.165 & 5.550 & 63.610 & 2.165 & 5.550 & 63.610 & 3.181 & 8.156 & 53.205 \\
\hline 5 & 1.851 & 4.745 & 68.355 & 1.851 & 4.745 & 68.355 & 2.856 & 7.324 & 60.528 \\
\hline 6 & 1.705 & 4.371 & 72.726 & 1.705 & 4.371 & 72.726 & 2.747 & 7.043 & 67.572 \\
\hline 7 & 1.274 & 3.267 & 75.993 & 1.274 & 3.267 & 75.993 & 2.318 & 5.943 & 73.515 \\
\hline 8 & 1.260 & 3.230 & 79.223 & 1.260 & 3.230 & 79.223 & 1.774 & 4.548 & 78.062 \\
\hline 9 & 1.019 & 2.612 & 81.835 & 1.019 & 2.612 & 81.835 & 1.471 & 3.773 & 81.835 \\
\hline 10 & .919 & 2.356 & 84.192 & & & & & & \\
\hline 11 & .760 & 1.948 & 86.139 & & & & & & \\
\hline 12 & .744 & 1.907 & 88.046 & & & & & & \\
\hline 13 & .662 & 1.697 & 89.744 & & & & & & \\
\hline 14 & .656 & 1.681 & 91.425 & & & & & & \\
\hline
\end{tabular}




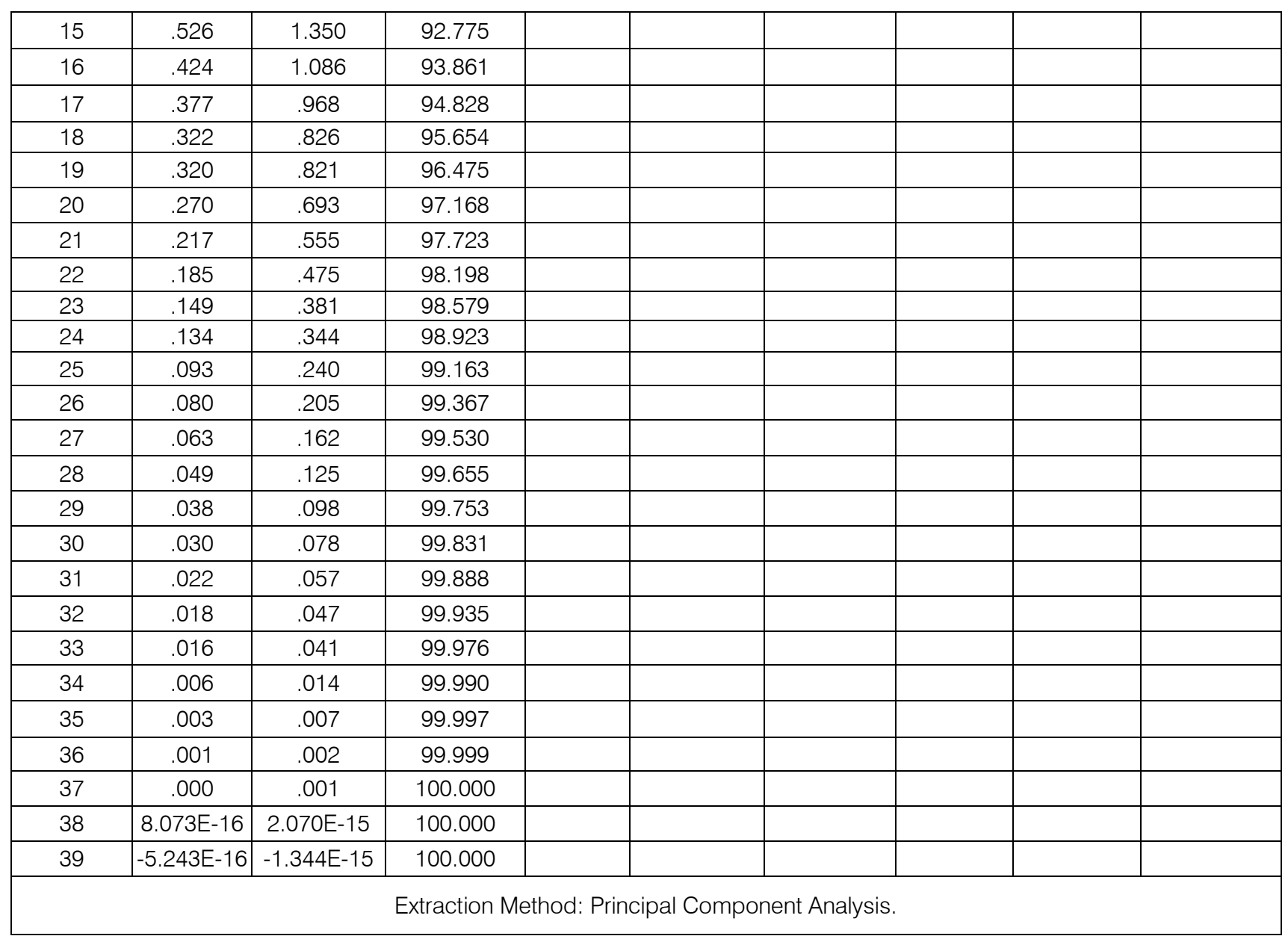

Data was checked for common bias; results from Table 3 above show that data in this case loaded on 39 components, and the first component is only explained 26.550 variation of data, therefore there is no common bias in the collected data.

\section{ii. Scale Validity}

In this research paper, the developed questionnaire utilizes 7-point Likert scales ranging from Agree Strongly to Disagree Strongly. It is essential to test the scales reliability to ensure the consistency of the questions of the questionnaire. Cronbach's Alpha is the important value to measure in the reliability test as it indicated how questions are interrelated in the questionnaire. The higher the value of Cronbach's Alpha, the more reliability of the scale. Below are tables for scale validity i.e. reliability test.

The basic statistical measures of the constructs (Mean and Standard Deviations) are illustrated in Table 4, Table 7 and Table 10. No missing data has been detected as seen that valid $\mathrm{N}=39$ is similar for all.

Reliability for self-driving car's specification construct's variables:

Table 4: Item statistics

\begin{tabular}{|c|c|c|c|}
\hline \multicolumn{4}{|c|}{ Item Statistics } \\
\hline & Mean & Std. Deviation & $\mathrm{N}$ \\
\hline P1V1comfort & 6.436 & .8521 & 39 \\
\hline P1V2safetysystem & 6.795 & .9782 & 39 \\
\hline P1V3luxury & 6.462 & .6426 & 39 \\
\hline P1V4wheels & 6.615 & .9066 & 39 \\
\hline P1V5brakingsystem & 6.846 & .3655 & 39 \\
\hline P1V6look & 6.436 & .9678 & 39 \\
\hline P1V7passengers & 6.282 & .9719 & 39 \\
\hline P1V8seating & 6.564 & .7538 & 39 \\
\hline P1V9entertainment & 6.282 & .9162 & 39 \\
\hline P1V10multi-view & 6.205 & .9509 & 39 \\
\hline P1V11engine & 6.462 & .8840 & 39 \\
\hline
\end{tabular}




\begin{tabular}{|c|c|c|c|}
\hline P1V12speed & 6.256 & .8801 & 39 \\
\hline P1V13complete-autonomous & 5.436 & 1.3916 & 39 \\
\hline P1V14partial-autonomous & 6.231 & .8099 & 39 \\
\hline
\end{tabular}

Table 5: Reliability Statistics - Cronbach's Alpha

\begin{tabular}{|c|c|c|}
\hline \multicolumn{3}{|c|}{ Reliability Statistics } \\
\hline Cronbach's Alpha & $\begin{array}{c}\text { Cronbach's Alpha Based on } \\
\text { Standardized Items }\end{array}$ & N of Items \\
\hline .771 & .773 & 14 \\
\hline
\end{tabular}

A reliability analysis was carried out. The scale covering 14 items i.e. construct's attributes. Cronbach's alpha in Table 5 showed the questionnaire to reach acceptable degree of reliability for the first construct i.e. self-driving car's specifications, Cronbach's Alpha $(\alpha)=$ 0.771 (Table5).

Table 6: Total Reliability Statistics

\begin{tabular}{|c|c|c|c|c|c|}
\hline \multicolumn{6}{|c|}{ Item-Total Statistics } \\
\hline & $\begin{array}{l}\text { Scale Mean if } \\
\text { Item Deleted }\end{array}$ & $\begin{array}{l}\text { Scale Variance } \\
\text { if Item Deleted }\end{array}$ & $\begin{array}{l}\text { Corrected Item- } \\
\text { Total Correlation }\end{array}$ & $\begin{array}{l}\text { Squared Multiple } \\
\text { Correlation }\end{array}$ & $\begin{array}{c}\text { Cronbach's } \\
\text { Alpha if Item } \\
\text { Deleted }\end{array}$ \\
\hline P1V1comfort & 82.872 & 40.167 & -.072 & .264 & .796 \\
\hline P1V2safetysystem & 82.513 & 37.099 & .173 & .534 & .779 \\
\hline P1V3luxury & 82.846 & 36.239 & .447 & .578 & .755 \\
\hline P1V4wheels & 82.692 & 34.640 & .436 & .696 & .753 \\
\hline P1V5brakingsystem & 82.462 & 38.939 & 228 & .409 & .770 \\
\hline P1V6look & 82.872 & 32.904 & .565 & .712 & .739 \\
\hline P1V7passengers & 83.026 & 32.710 & .581 & .741 & .737 \\
\hline P1V8seating & 82.744 & 34.038 & .626 & .841 & .739 \\
\hline P1V9entertainment & 83.026 & 34.289 & .465 & .737 & .750 \\
\hline P1V10multi-view & 83.103 & 32.831 & .585 & .728 & .737 \\
\hline P1V11engine & 82.846 & 35.502 & .364 & .777 & .760 \\
\hline P1V12speed & 83.051 & 35.260 & .390 & .386 & .757 \\
\hline P1V13complete-autonomous & 83.872 & 31.220 & .447 & .521 & .755 \\
\hline P1V14partial-autonomous & 83.077 & 36.915 & .258 & .438 & .768 \\
\hline
\end{tabular}

Table 6 shows that most items appeared to be worthy of retention, resulting in a decrease in the alpha if deleted. Except two items i.e. P1V1comfort and P1V2 safety system, which would increase the alpha to $\alpha=$ 0.796 and $\alpha=0.779$. There is no need to delete these items since the $\alpha=0.771$ which is high and the increase in Cronbach's Alpha if item deleted is not significant.

Reliability for self-driving car's features construct's variables:

Table 7: Item statistics

\begin{tabular}{|c|c|c|c|}
\hline \multicolumn{4}{|c|}{ Item Statistics } \\
\hline & Mean & Std. Deviation & $\mathrm{N}$ \\
\hline P2V1safe & 5.513 & 1.2539 & 39 \\
\hline P2V2speed-limit & 5.641 & 1.1353 & 39 \\
\hline P2V3road-rules & 5.564 & 1.3138 & 39 \\
\hline P2V4reduce-accidents & 5.205 & 1.4360 & 39 \\
\hline P2V5safety-encourage & 5.718 & 1.1227 & 39 \\
\hline P2V6reach-destination & 5.231 & 1.5638 & 39 \\
\hline P2V7fuel & 5.436 & 1.3533 & 39 \\
\hline P2V8performane-encourage & 5.615 & 1.1611 & 39 \\
\hline P2V9easy-to-use & 5.564 & 1.3138 & 39 \\
\hline P2V10easy-to-learn & 5.897 & 1.0953 & 39 \\
\hline P2V11easy-encourage & 5.821 & .8545 & 39 \\
\hline P2V12efficient-destination & 5.513 & 1.2952 & 39 \\
\hline P2V13 benefit-comfort & 5.974 & 1.0127 & 39 \\
\hline P2V14 reliable & 5.179 & 1.4303 & 39 \\
\hline P2V15 benefit-safe & 5.333 & 1.3045 & 39 \\
\hline
\end{tabular}




\begin{tabular}{|c|c|c|c|}
\hline P2V16 reduce-traffic & 5.333 & 1.2425 & 39 \\
\hline P2V17road-time & 6.000 & 1.1471 & 39 \\
\hline P2V18 reduce-pleasure & 6.026 & 1.2028 & 39 \\
\hline P2V19 benefit-encourage & 5.795 & 1.4722 & 39 \\
\hline
\end{tabular}

Table 8: Reliability Statistics - Cronbach's Alpha

\begin{tabular}{|c|c|c|}
\hline \multicolumn{3}{|c|}{ Reliability Statistics } \\
\hline Cronbach's Alpha & $\begin{array}{c}\text { Cronbach's Alpha Based on } \\
\text { Standardized Items }\end{array}$ & N of Items \\
\hline .957 & .958 & 19 \\
\hline
\end{tabular}

A reliability analysis was carried out. The scale covering 19 items i.e. construct's variables. Cronbach's alpha in Table 8 showed the questionnaire to reach high

degree of reliability for the second construct i.e. selfdriving car's features, $\alpha=0.957$ (Table8).

Table 9: Total Reliability Statistics

\begin{tabular}{|c|c|c|c|c|c|}
\hline \multicolumn{7}{|c|}{ Item-Total Statistics } \\
\hline & $\begin{array}{c}\text { Scale Mean if } \\
\text { Item Deleted }\end{array}$ & $\begin{array}{c}\text { Scale Variance } \\
\text { if Item Deleted }\end{array}$ & $\begin{array}{c}\text { Corrected Item- } \\
\text { Total Correlation }\end{array}$ & $\begin{array}{c}\text { Squared Multiple } \\
\text { Correlation }\end{array}$ & $\begin{array}{c}\text { Cronbach's Alpha } \\
\text { if Item Deleted }\end{array}$ \\
\hline P2V1safe & 100.846 & 289.291 & .728 & .844 & .954 \\
\hline P2V2speed-limit & 100.718 & 290.366 & .782 & .750 & .954 \\
\hline P2V3road-rules & 100.795 & 288.536 & .709 & .789 & .955 \\
\hline P2V4reduce-accidents & 101.154 & 282.660 & .770 & .883 & .954 \\
\hline P2V5safety-encourage & 100.641 & 293.078 & .718 & .909 & .955 \\
\hline P2V6reach-destination & 101.128 & 279.536 & .764 & .808 & .954 \\
\hline P2V7fuel & 100.923 & 289.178 & .672 & .872 & .955 \\
\hline P2V8performane-encourage & 100.744 & 289.143 & .796 & .857 & .953 \\
\hline P2V9easy-to-use & 100.795 & 282.588 & .851 & .892 & .952 \\
\hline P2V10easy-to-learn & 100.462 & 299.045 & .572 & .897 & .956 \\
\hline P2V11easy-encourage & 100.538 & 300.150 & .711 & .826 & .955 \\
\hline P2V12efficient-destination & 100.846 & 288.239 & .728 & .764 & .954 \\
\hline P2V13 benefit-comfort & 100.385 & 295.874 & .718 & .872 & .955 \\
\hline P2V14 reliable & 101.179 & 282.625 & .775 & .807 & .954 \\
\hline P2V15 benefit-safe & 101.026 & 284.078 & .822 & .936 & .953 \\
\hline P2V16 reduce-traffic & 101.026 & 292.920 & .646 & .704 & .956 \\
\hline P2V17road-time & 100.359 & 293.131 & .699 & .837 & .955 \\
\hline P2V18 reduce-pleasure & 100.333 & 290.965 & .719 & .808 & .955 \\
\hline P2V19 benefit-encourage & 100.564 & 291.358 & .565 & .674 & .957 \\
\hline
\end{tabular}

Table 9 shows that all items appeared to be worthy of retention, resulting in a decrease in the alpha if

Reliability for intention to turn into using selfdeleted.

Table 10: Item statistics

\begin{tabular}{|c|c|c|c|}
\hline \multicolumn{4}{|c|}{ Item Statistics } \\
\hline & Mean & Std. Deviation & $\mathrm{N}$ \\
\hline P3V1 willing-pay & 5.103 & 1.4653 & 39 \\
\hline P3V2 lot-benefits & 5.872 & .9509 & 39 \\
\hline P3V3 recommend-use & 5.692 & 1.3984 & 39 \\
\hline P3V4 ease-of-use & 5.692 & 1.2387 & 39 \\
\hline P3V5 willing-buy & 5.410 & 1.4818 & 39 \\
\hline P3V6 own-idea & 5.769 & 1.3468 & 39 \\
\hline
\end{tabular}


Table 11: Reliability Statistics - Cronbach's Alpha

\begin{tabular}{|c|c|c|}
\hline \multicolumn{3}{|c|}{ Reliability Statistics } \\
\hline Cronbach's Alpha & $\begin{array}{c}\text { Cronbach's Alpha Based on } \\
\text { Standardized Items }\end{array}$ & N of Items \\
\hline .942 & .946 & 6 \\
\hline
\end{tabular}

A reliability analysis was carried out. The scale covering 6 items i.e. construct's variables. Cronbach's alpha in Table 11 showed the questionnaire to reach high degree of reliability for the third construct i.e. intention to turn into using self-driving car, $\alpha=0.942$ (Table11).

Table 12: Total Reliability Statistics

\begin{tabular}{|c|c|c|c|c|c|}
\hline \multicolumn{7}{|c|}{ Item-Total Statistics } \\
\hline & $\begin{array}{c}\text { Scale Mean if Item } \\
\text { Deleted }\end{array}$ & $\begin{array}{c}\text { Scale Variance } \\
\text { if Item Deleted }\end{array}$ & $\begin{array}{c}\text { Corrected Item- } \\
\text { Total Correlation }\end{array}$ & $\begin{array}{c}\text { Squared Multiple } \\
\text { Correlation }\end{array}$ & $\begin{array}{c}\text { Cronbach's } \\
\text { Alpha if Item } \\
\text { Deleted }\end{array}$ \\
\hline P3V1 willing-pay & 28.436 & 33.779 & .773 & .620 & .939 \\
\hline P3V2 lot-benefits & 27.667 & 38.754 & .797 & .703 & .939 \\
\hline P3V3 recommend-use & 27.846 & 33.028 & .878 & .809 & .925 \\
\hline P3V4 ease-of-use & 27.846 & 35.818 & .792 & .701 & .935 \\
\hline P3V5 willing-buy & 28.128 & 32.062 & .884 & .865 & .924 \\
\hline P3V6 own-idea & 27.769 & 33.498 & .884 & .850 & .924 \\
\hline
\end{tabular}

Table 12 shows that all items appeared to be worthy of retention, resulting in a decrease in the alpha if deleted.

From construct and validity test it was found that the there is no common bias in the collected data and the reliability test presented high score of Cronbach's Alpha which indicated high degree of reliability.

\section{b) Univariate statistics}

Data were collected and organized, the univariate test is simple test conducted in order to explore the data and measure the frequencies of attributes as well as mean, median and mode. Univariate test utilized for description purposes; it doesn't involve finding relationships between data.

In this research paper, questionnaire consists of 39 questions, univariate statistical test carried out for exploring frequencies and description purposes. Appendix B consists of the Univariate Statistics for construct's attributes as well as Univariate Statistics for Demographics. Tables below consists of comparison between frequencies of construct's attributes:

i. Comparison of the percent of each of the specification of self-driving car that user interested in:

When comparing the self-driving car's specifications; statistics presented that respondents highly care about safety specifications. Statistics as well represented the following as seen in Table 13 and Figure 3 below:

1. Around $95 \%$ of respondents care about comfort specifications.
2. More than $97 \%$ of respondents with different degree of agreement care about safety, luxury, braking system, car's outside look, speed, number of passengers, wheels and seating's specifications, engine specifications of self-driving car.

3. Around $92 \%$ of respondents care about entertainment specifications.

4. Partial-autonomous cars are much preferred than complete autonomous cars.

From all above, it is clear that people highly care about all the specifications of the self-driving car. 
Table 13: Self-driving car specifications frequencies

\begin{tabular}{|c|c|c|c|c|c|c|c|c|c|c|c|c|c|c|}
\hline & 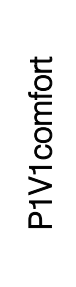 & 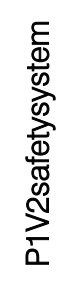 & 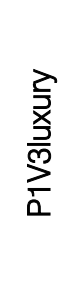 & $\begin{array}{l}\frac{\infty}{\Phi} \\
\mathbb{\Phi} \\
\frac{\infty}{3} \\
\sum_{0}^{\infty} \\
\sum_{0}\end{array}$ & 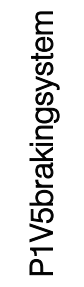 & $\begin{array}{l}\frac{y}{8} \\
\frac{0}{0} \\
\frac{1}{\alpha}\end{array}$ & 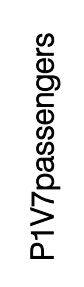 & 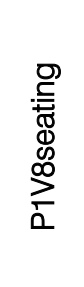 & 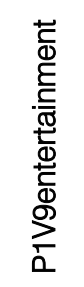 & 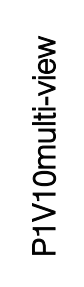 & 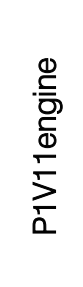 & $\begin{array}{l}\overline{8} \\
\mathbb{0} \\
\frac{0}{0} \\
\stackrel{N}{N} \\
\sum_{0}\end{array}$ & 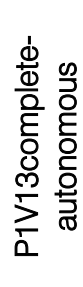 & 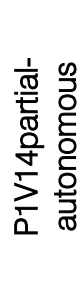 \\
\hline Strongly Disagree & 0 & 2.6 & 0 & 0 & 0 & 0 & 0 & 0 & 0 & 0 & 0 & 0 & 0 & 0 \\
\hline Disagree & 0 & 0 & 0 & 2.6 & 0 & 2.6 & 2.6 & 0 & 0 & 0 & 0 & 0 & 5.1 & 0 \\
\hline Slightly Disagree & 2.6 & 0 & 0 & 0 & 0 & 0 & 0 & 0 & 0 & 2.6 & 2.6 & 2.6 & 5.1 & 0 \\
\hline Neutral & 2.6 & 0 & 0 & 0 & 0 & 0 & 0 & 2.6 & 7.7 & 2.6 & 0 & 0 & 10.3 & 2.6 \\
\hline Slightly Agree & 0 & 0 & 7.7 & 2.6 & 0 & 7.7 & 10.3 & 7.7 & 7.7 & 12.8 & 10.3 & 12.8 & 25.6 & 15.4 \\
\hline Agree & 38.5 & 5.1 & 38.5 & 20.5 & 15.4 & 28.2 & 38.5 & 20.5 & 33.3 & 35.9 & 23.1 & 38.5 & 28.2 & 38.5 \\
\hline Agree Strongly & 56.4 & 92.3 & 53.8 & 74.4 & 84.6 & 61.5 & 48.7 & 69.2 & 51.3 & 46.2 & 64.1 & 46.2 & 25.6 & 43.6 \\
\hline
\end{tabular}

\section{Car specification that user interested and care about}
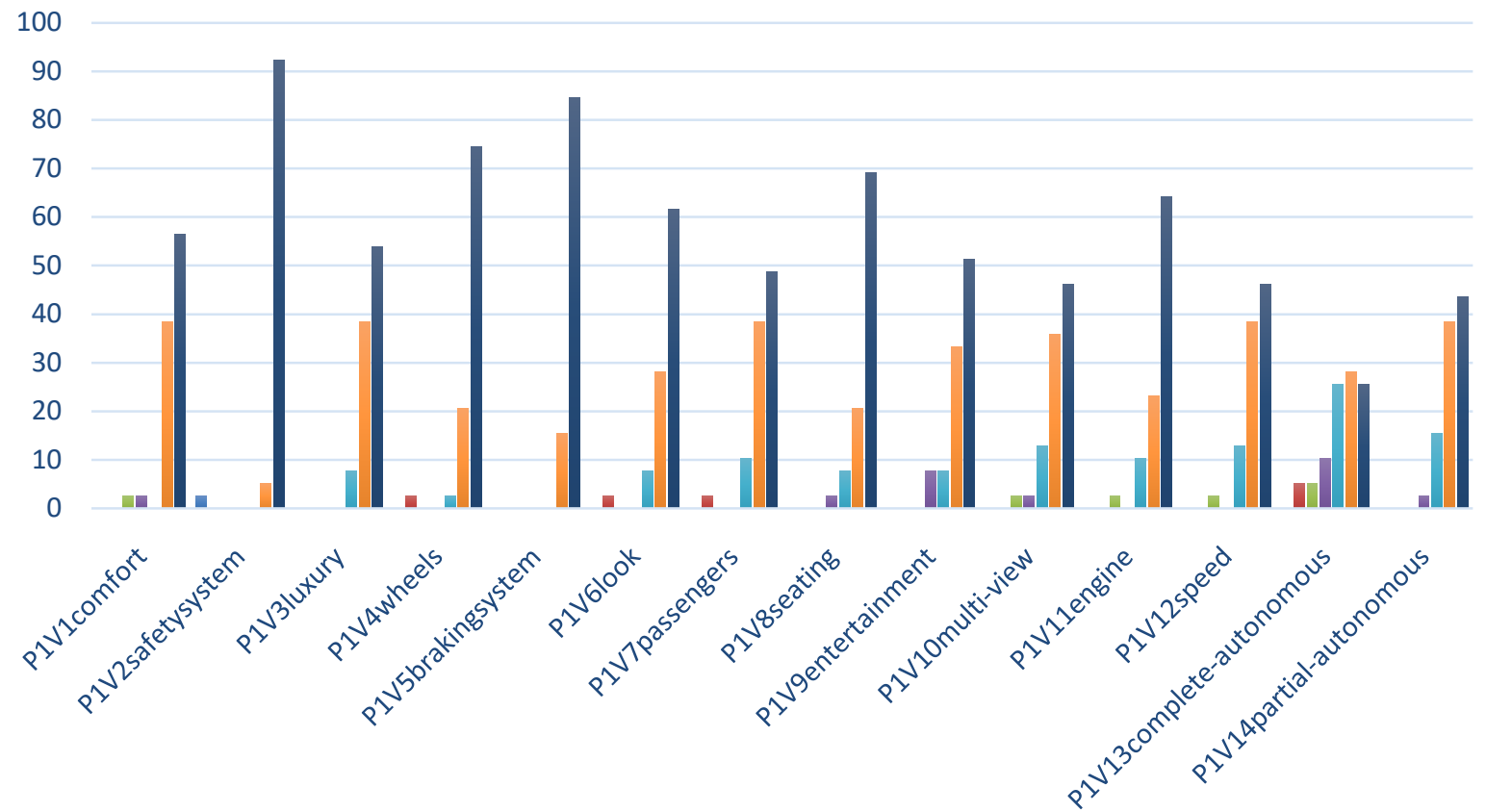

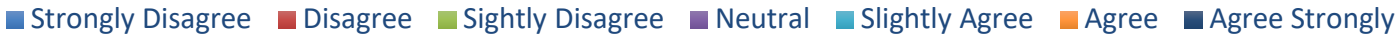

\section{Figure 3: Self-driving car specifications frequencies}

ii. Comparison of the percent of each of the user's expectations of self-driving car safety features:

Respondents highly care about safety of selfdriving car. Statistics represented the following as seen in Table 14 and Figure 4 below:

1. More than84\% of respondents believe that selfdriving car is safe.

2. More than $87 \%$ of respondents believe that selfdriving car will never exceed speed limit.
3. More than $79 \%$ of respondents believe that selfdriving car will never break road rules.

4. More than $69 \%$ of respondents believe that selfdriving car will reduce car accidents while around $13 \%$ disagree that self-driving car will reduce car accidents.

5. More than $87 \%$ of respondents believe that selfdriving car safety features have great impact that will encourage people to buy such car. 
From all above, people highly believe that self-driving car would be a safe car, and safety features would encourage people to buy such car.

Table 14: Expected safety features frequencies

\begin{tabular}{|c|c|c|c|c|c|}
\hline & 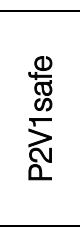 & 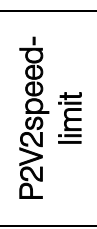 & 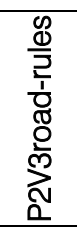 & 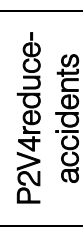 & 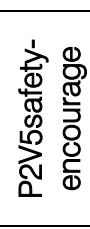 \\
\hline Strongly Disagree & 2.6 & 0 & 0 & 2.6 & 0 \\
\hline Disagree & 0 & 2.6 & 2.6 & 0 & 2.6 \\
\hline Slightly Disagree & 2.6 & 2.6 & 5.1 & 10.3 & 0 \\
\hline Neutral & 10.3 & 7.7 & 12.8 & 17.9 & 10.3 \\
\hline Slightly Agree & 28.2 & 23.1 & 20.5 & 17.9 & 23.1 \\
\hline Agree & 35.9 & 43.6 & 30.8 & 33.3 & 38.5 \\
\hline Agree Strongly & 20.5 & 20.5 & 28.2 & 17.9 & 25.6 \\
\hline
\end{tabular}

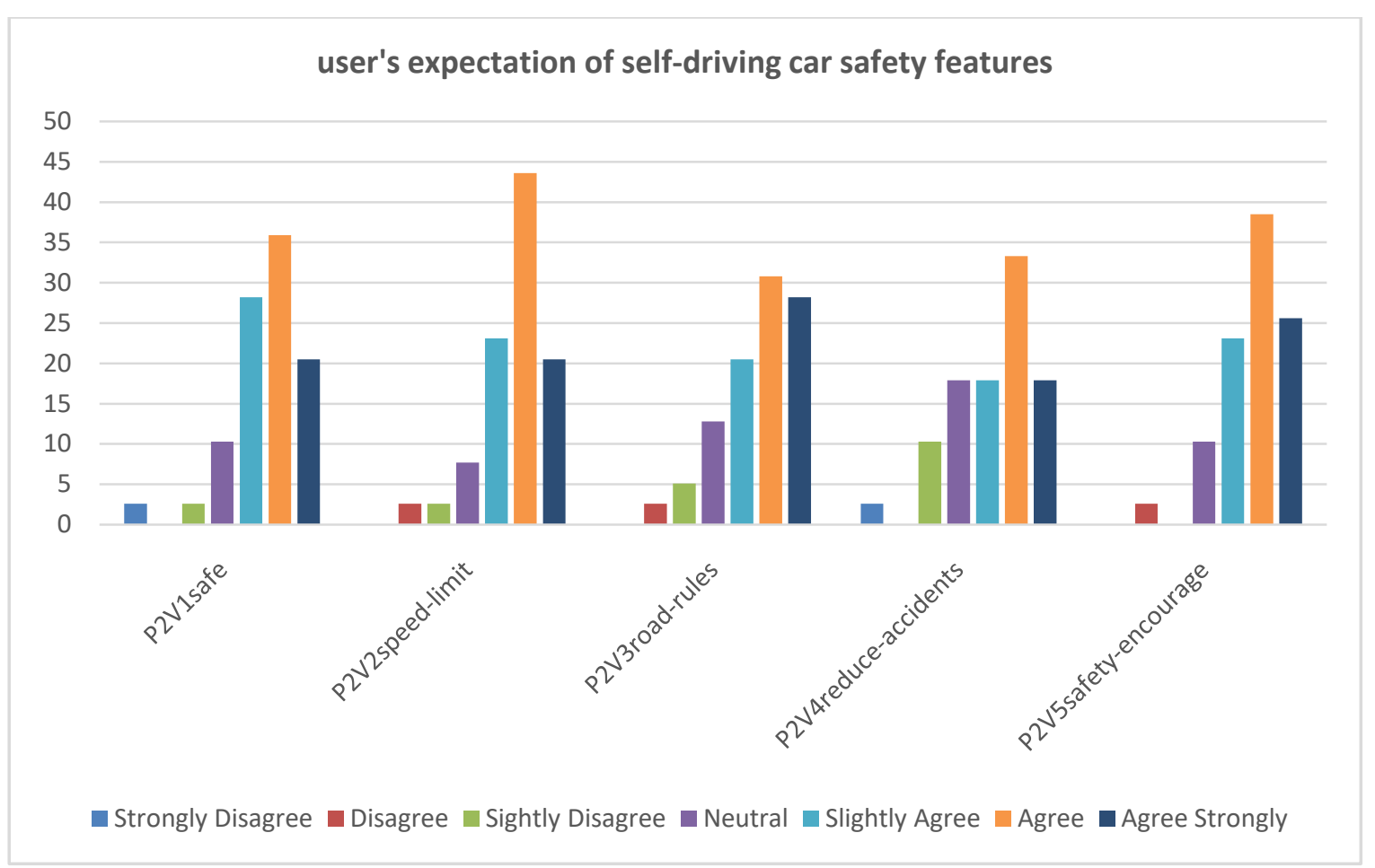

Figure 4: Expected safety features frequencies

iii. Comparison of the percent of each of the user's expectations of self-driving car performance:

Respondents have high expectations about performance of self-driving car. Statistics represented the following as seen in Table 15 and Figure 5 below:

1. More than $74 \%$ of respondents believe that selfdriving car would efficiently reach destination fast, on the other side, around 15\% disagree about this.

2. $80 \%$ of respondents believe that self-driving car will not consume much fuel.

3. More than $87 \%$ of respondents believe that the performance features of self-driving car will encourage them to buy it.
From all above, people highly believe that self-driving car would have great performance, and performance features would encourage people to buy such car. 
Table 15: Expected performance features frequencies

\begin{tabular}{|c|c|c|c|}
\hline & P2V6reach-destination & P2V7fuel & P2V8performane-encourage \\
\hline Strongly Disagree & 2.6 & 0 & 0 \\
\hline Disagree & 5.1 & 2.6 & 2.6 \\
\hline Slightly Disagree & 7.7 & 10.3 & 2.6 \\
\hline Neutral & 10.3 & 5.1 & 7.7 \\
\hline Slightly Agree & 20.5 & 30.8 & 28.2 \\
\hline Agree & 33.3 & 25.6 & 35.9 \\
\hline Agree Strongly & 20.5 & 25.6 & 23.1 \\
\hline
\end{tabular}

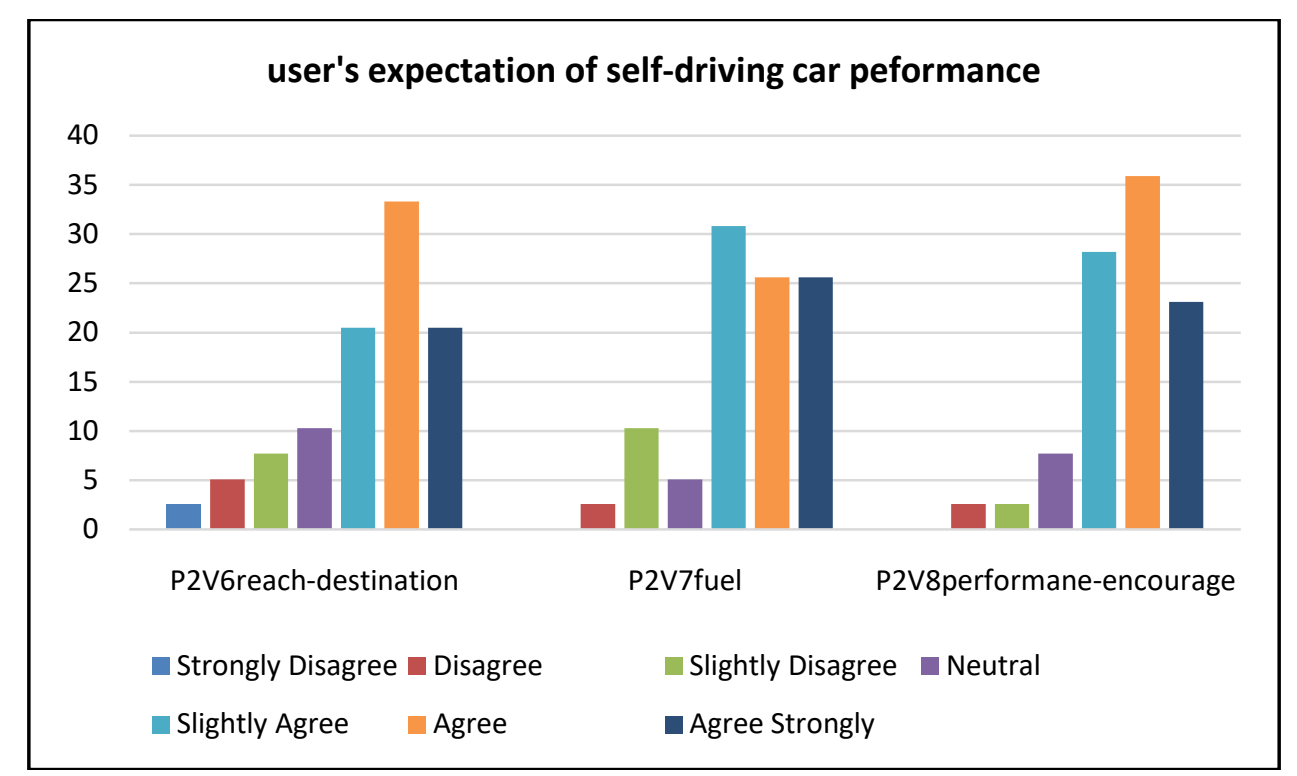

Figure 5: Expected performance features frequencies

iv. Comparison of the percent of each of the user's expectations of self-driving car ease of use features:

Respondents have high expectations about Ease of Use features of self-driving car. Statistics represented the following as seen in Table 16 and Figure 6 below:

1. Around $90 \%$ of respondents believe that self-driving car would be easy to use.
2. Around $95 \%$ of respondents believe that they will learn how to use self-driving car fast.

3. More than $92 \%$ of respondents believe that the Ease of Use features of self-driving car will encourage them to buy it.

From all above, people highly believe that selfdriving car would be easy to use, and they will learn fast how to use it, people as well believe that Ease of Use features would encourage them to buy such car.

Table 16: Expected Ease of Use features frequencies

\begin{tabular}{|c|c|c|c|}
\hline & P2V9easy-to-use & P2V10easy-to-learn & P2V11easy-encourage \\
\hline Strongly Disagree & 0 & 0 & 0 \\
\hline Disagree & 7.7 & 2.6 & 0 \\
\hline Slightly Disagree & 0 & 2.6 & 0 \\
\hline Neutral & 2.6 & 0 & 7.7 \\
\hline Slightly Agree & 30.8 & 23.1 & 23.1 \\
\hline Agree & 35.9 & 41 & 48.7 \\
\hline Agree Strongly & 23.1 & 30.8 & 20.5 \\
\hline
\end{tabular}




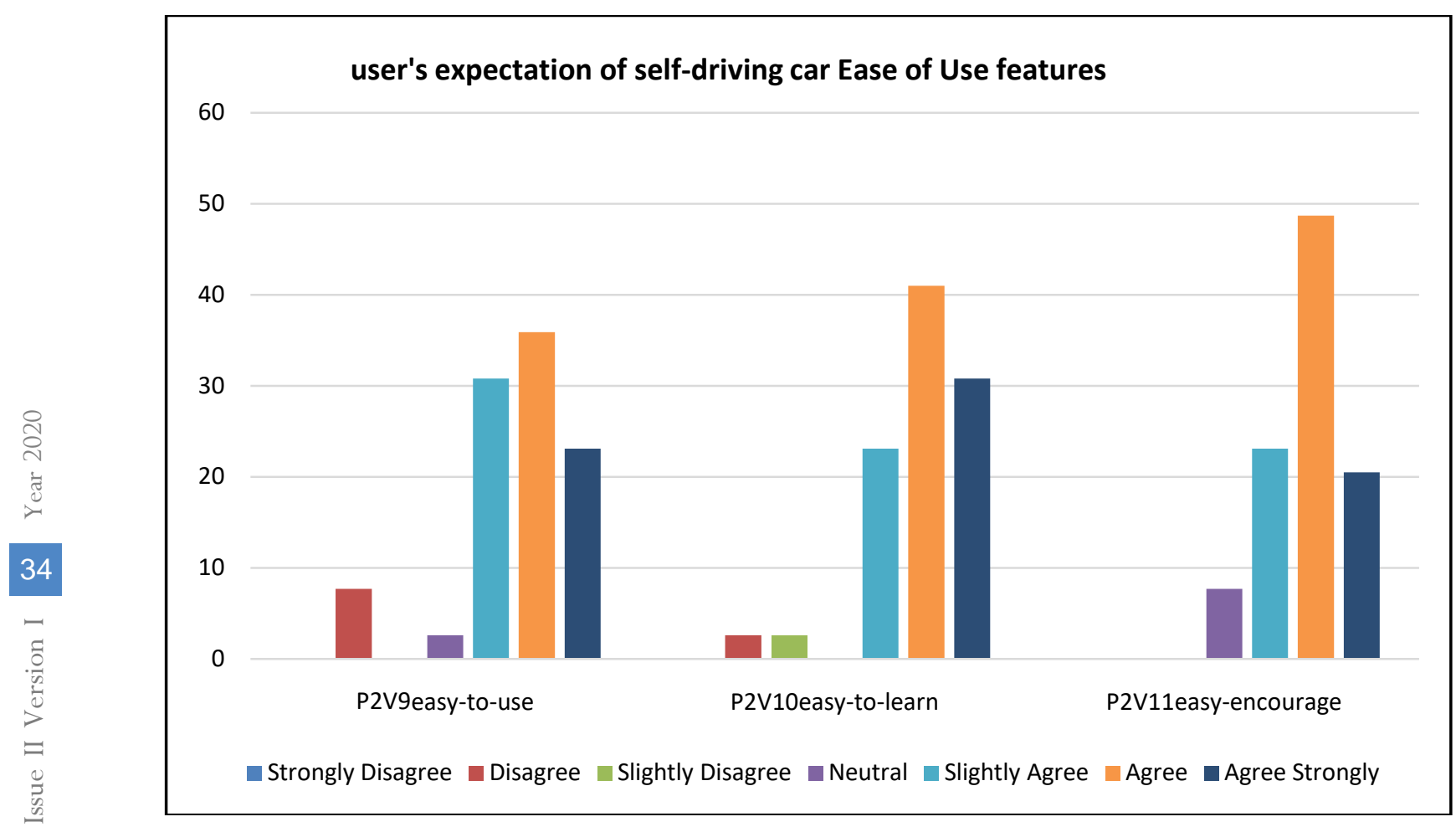

Figure 6: Expected Ease of Use features frequencies

v. Comparison of the percent of each of the user's expectations of self-driving usefulness:

Respondents have high expectations about the usefulness of self-driving car. Statistics represented the following as seen in Table 17 and Figure 7 below:

1. More than $92 \%$ of respondents believe that selfdriving car would provide comfort to them.

2. More than $74 \%$ of respondents believe that selfdriving car would be reliable car and it would reduce traffic jam.
3. More than $87 \%$ of respondents believe that selfdriving car will reduce the pressure due to driving.

4. More than $87 \%$ of respondents believe that the benefits of self-driving car will encourage them to buy it.

From all above, people highly believe that selfdriving car would provide benefits to them and these usefulness features would encourage them to buy such car.

Table 17: Expected Usefulness features frequencies

\begin{tabular}{|c|c|c|c|c|c|c|c|c|}
\hline & 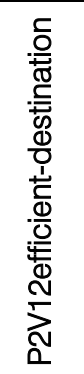 & 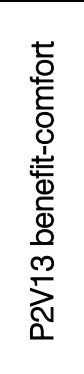 & 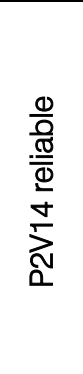 & 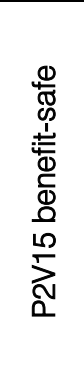 & 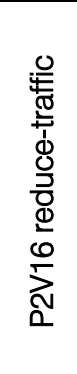 & 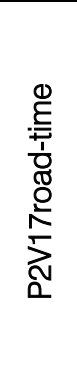 & 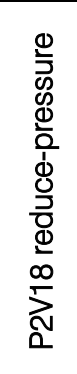 & 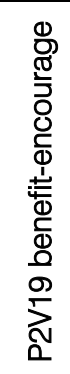 \\
\hline Strongly Disagree & 2.6 & 0 & 0 & 2.6 & 0 & 0 & 0 & 2.6 \\
\hline Disagree & 0 & 0 & 7.7 & 2.6 & 0 & 0 & 2.6 & 2.6 \\
\hline Slightly Disagree & 2.6 & 2.6 & 5.1 & 0 & 7.7 & 5.1 & 0 & 5.1 \\
\hline Neutral & 12.8 & 5.1 & 12.8 & 15.4 & 17.9 & 5.1 & 10.3 & 2.6 \\
\hline Slightly Agree & 25.6 & 20.5 & 28.2 & 28.2 & 30.8 & 17.9 & 12.8 & 15.4 \\
\hline Agree & 33.3 & 35.9 & 28.2 & 35.9 & 20.5 & 28.2 & 28.2 & 33.3 \\
\hline Agree Strongly & 23.1 & 35.9 & 17.9 & 15.4 & 23.1 & 43.6 & 46.2 & 38.5 \\
\hline
\end{tabular}




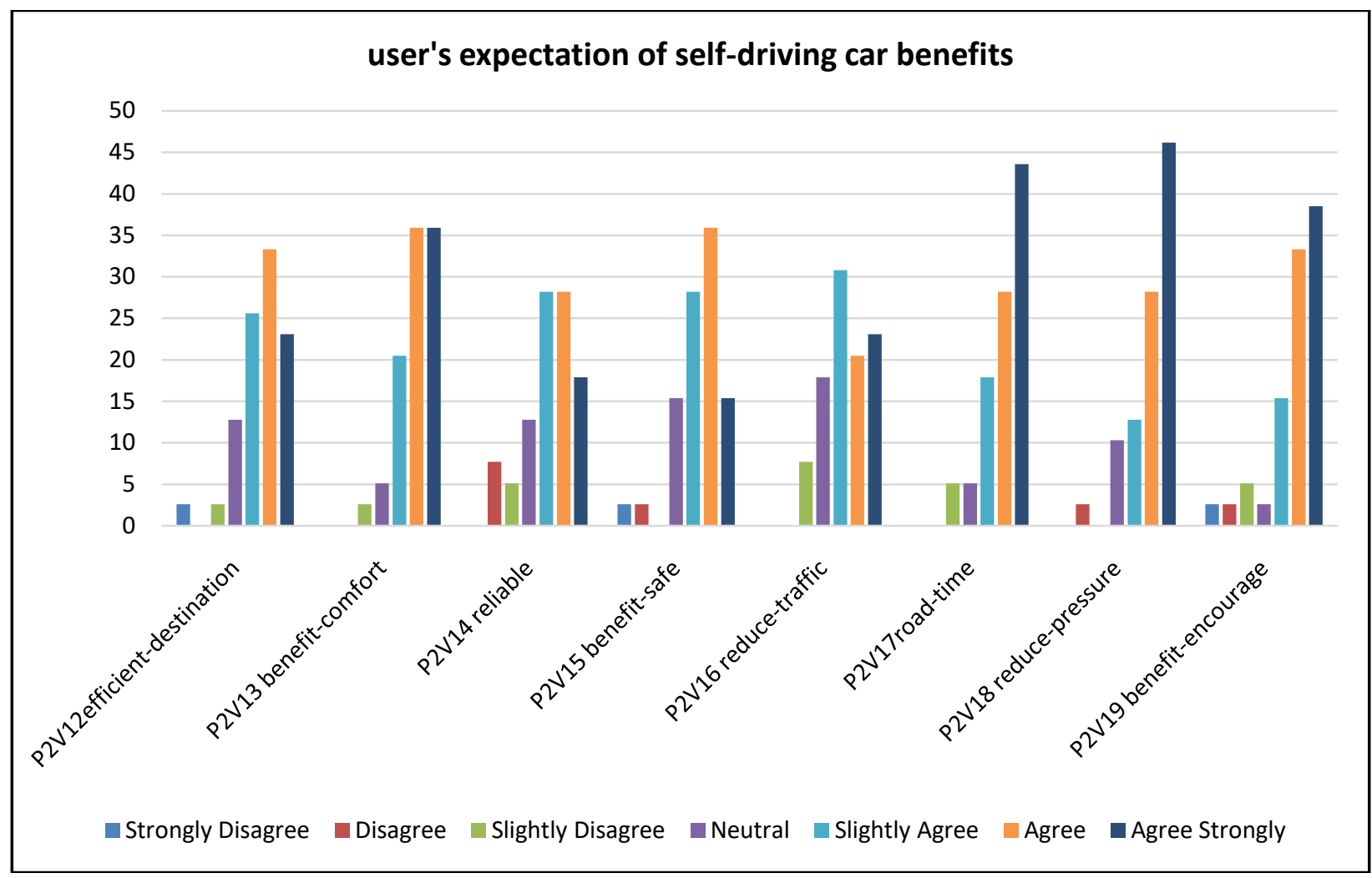

Figure 7: Expected Usefulness features frequencies

vi. Comparison of the percent of the attributes of the people's intention to turn into using self-driving car construct:

Respondents have high intention to turn into using self-driving car. Statistics represented the following as seen in Table 18 and Figure 8 below:

1. More than $71 \%$ of respondents are willing to pay even more for the self-driving car while around 13\% disagree about this.
2. $77 \%$ of respondents would recommend using selfdriving car.

3. More than $87 \%$ think that owning self-driving car is a good idea even that only $77 \%$ of respondents have the intention to buy self-driving car in the future while around $10 \%$ haven't the intention to buy such car in the future.

From all above, people in UAE have great intention to turn into using self-driving car in the future.

Table 18: Intention to turn into using self-driving car frequencies

\begin{tabular}{|c|c|c|c|c|c|c|}
\hline & 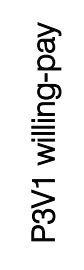 & 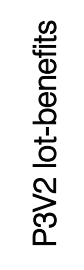 & 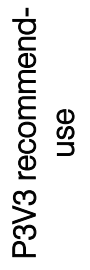 & 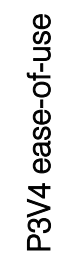 & 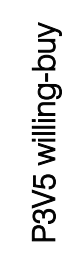 & 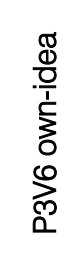 \\
\hline Strongly Disagree & 2.6 & 0 & 2.6 & 0 & 0 & 2.6 \\
\hline Disagree & 2.6 & 0 & 0 & 2.6 & 7.7 & 0 \\
\hline Slightly Disagree & 10.3 & 0 & 0 & 2.6 & 2.6 & 2.6 \\
\hline Neutral & 12.8 & 10.3 & 20.5 & 10.3 & 12.8 & 7.7 \\
\hline Slightly Agree & 25.6 & 20.5 & 15.4 & 23.1 & 23.1 & 25.6 \\
\hline Agree & 30.8 & 41 & 23.1 & 30.8 & 25.6 & 23.1 \\
\hline Agree Strongly & 15.4 & 28.2 & 38.5 & 30.8 & 28.2 & 38.5 \\
\hline
\end{tabular}




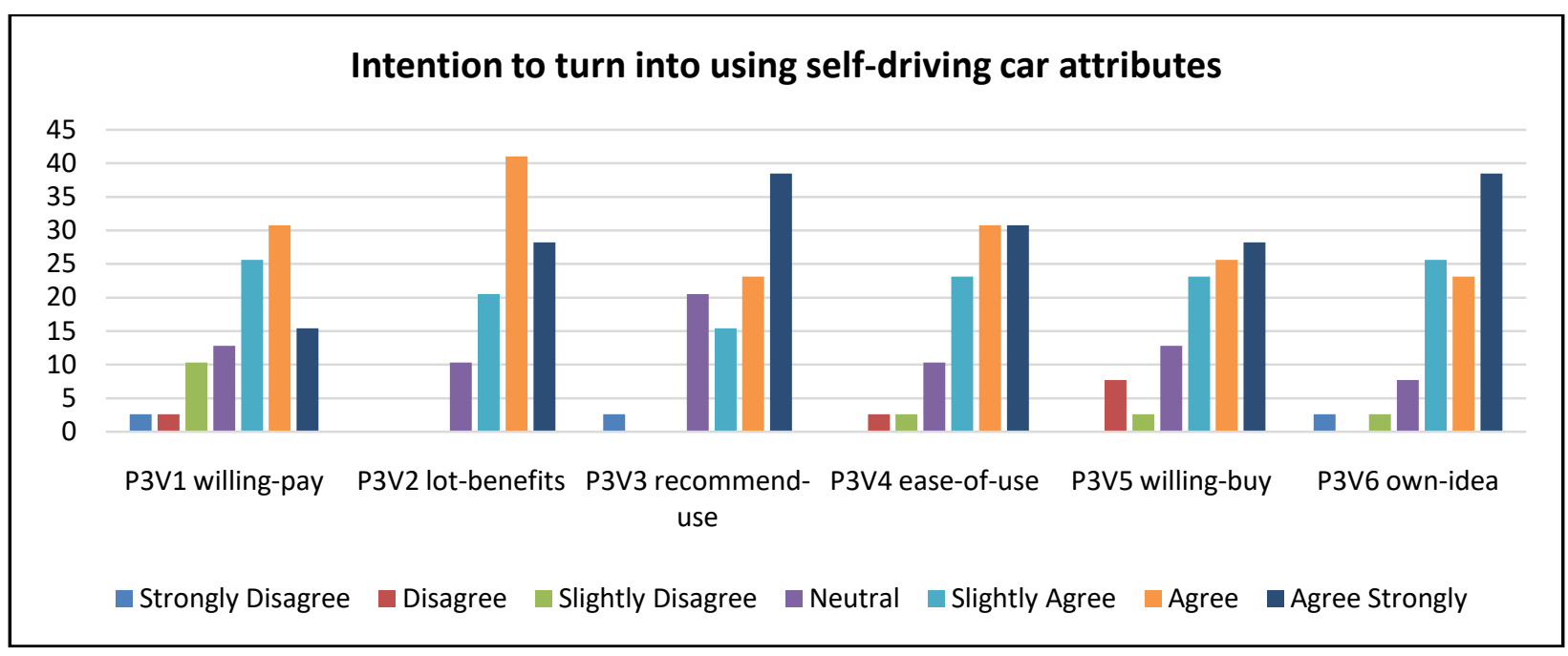

Figure 8: Intention to turn into using self-driving car frequencies

\section{c) Results of Research Questions and Hypothesis Testing}

In order to investigate the answer for the research questions and testing the defined hypothesis for the research, number of statistical tests are conducted as presented below:

i. Frequency test to measure UAE people interest about self-driving car's specifications:

Q1: To what extent UAE people care about specifications of the self-driving car?

H1: UAE people highly care about the specification of self-driving car

When comparing the self-driving car's specifications; statistics presented that respondents highly care about self-driving car's specifications. Statistics as well represented the following as seen in Table 19 and Figure 9 below:
1. Around $95 \%$ of respondents care about comfort specifications.

2. More than $97 \%$ of respondents with different degree of agreement care about safety, luxury, braking system, car's outside look, speed, number of passengers, wheels and seating's specifications, engine specifications of self-driving car.

3. Around $92 \%$ of respondents care about entertainment specifications.

4. Partial-autonomous cars are much preferred than complete autonomous cars.

From all above, it is clear that UAE people highly care about all the specifications of the self-driving car, Thus Hypothesis $\mathrm{H} 1$ is accepted.

Table 19: Specifications of self-driving car that UAE people car about

\begin{tabular}{|c|c|c|c|c|c|c|c|c|c|c|c|c|c|c|}
\hline & 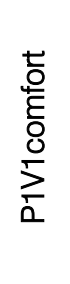 & 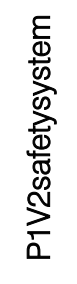 & 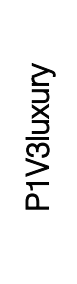 & 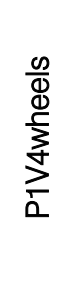 & 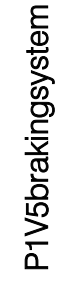 & $\frac{r}{8}$ & 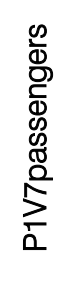 & 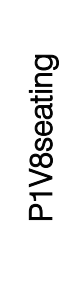 & 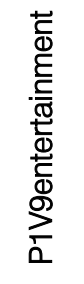 & 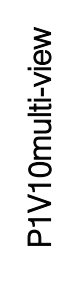 & 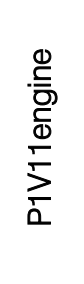 & 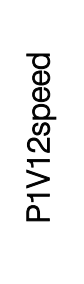 & 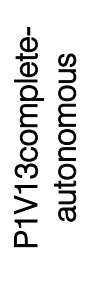 & 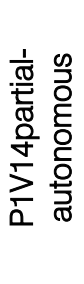 \\
\hline Strongly Disagree & 0 & 2.6 & 0 & 0 & 0 & 0 & 0 & 0 & 0 & 0 & 0 & 0 & 0 & 0 \\
\hline Disagree & 0 & 0 & 0 & 2.6 & 0 & 2.6 & 2.6 & 0 & 0 & 0 & 0 & 0 & 5.1 & 0 \\
\hline Slightly Disagree & 2.6 & 0 & 0 & 0 & 0 & 0 & 0 & 0 & 0 & 2.6 & 2.6 & 2.6 & 5.1 & 0 \\
\hline Neutral & 2.6 & 0 & 0 & 0 & 0 & 0 & 0 & 2.6 & 7.7 & 2.6 & 0 & 0 & 10.3 & 2.6 \\
\hline Slightly Agree & 0 & 0 & 7.7 & 2.6 & 0 & 7.7 & 10.3 & 7.7 & 7.7 & 12.8 & 10.3 & 12.8 & 25.6 & 15.4 \\
\hline Agree & 38.5 & 5.1 & 38.5 & 20.5 & 15.4 & 28.2 & 38.5 & 20.5 & 33.3 & 35.9 & 23.1 & 38.5 & 28.2 & 38.5 \\
\hline Agree Strongly & 56.4 & 92.3 & 53.8 & 74.4 & 84.6 & 61.5 & 48.7 & 69.2 & 51.3 & 46.2 & 64.1 & 46.2 & 25.6 & 43.6 \\
\hline
\end{tabular}




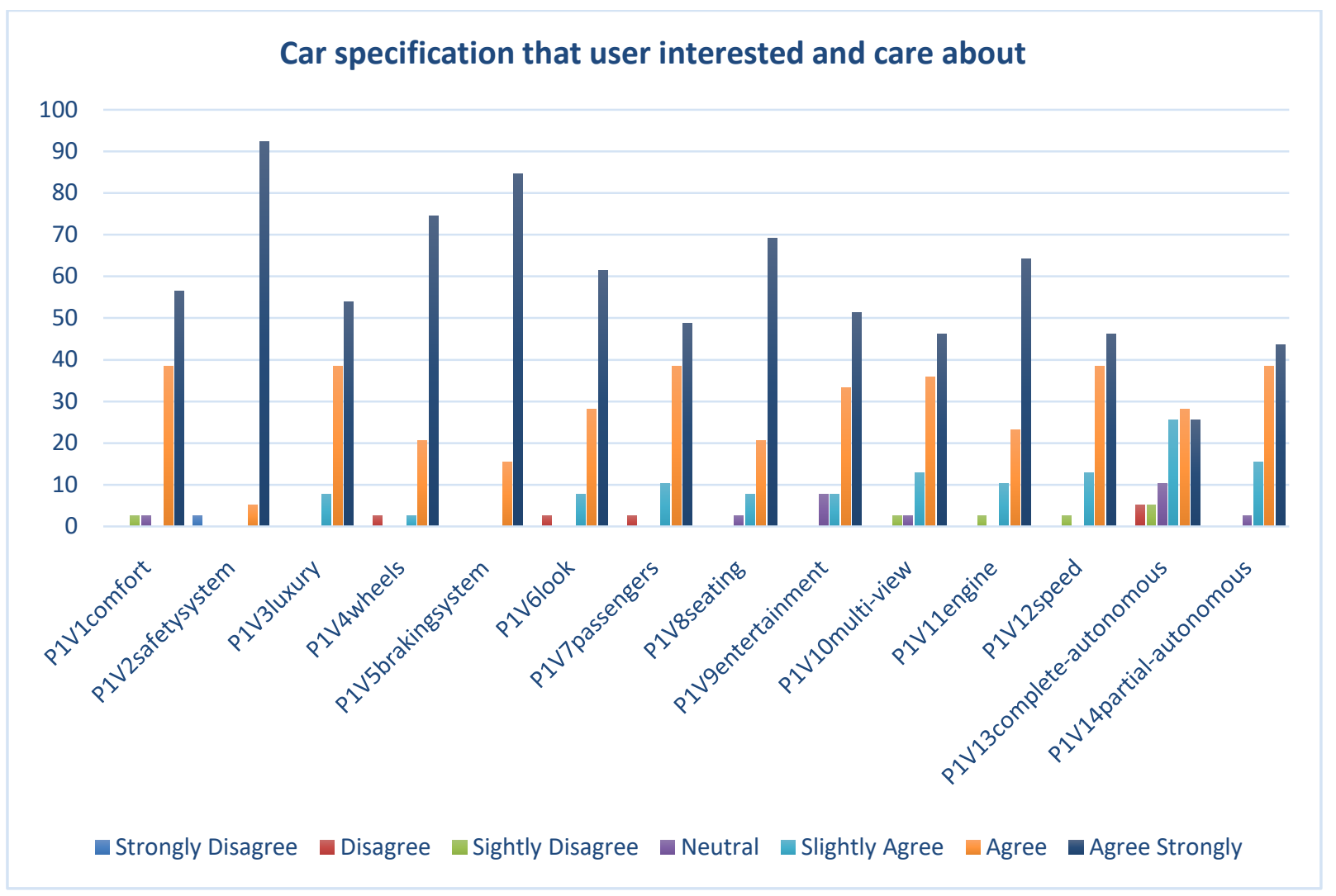

Figure 9: Specifications of self-driving car that UAE people car about

ii. Correlation test and Regression test to measure the relationship between self-driving car's specification and people's intention to turn into using self-driving car:

Q2: Does the specifications of the self-driving car impact the UAE people's intention to turn into using selfdriving car?
H2: There is significant association between self-driving car's specifications and the UAE people's intention to turn into using self-driving car.

For this research question, global variables identified as following:

INT: intention into using self-driving car

SPC: specification of self-driving car

Correlation Test:

Table 20: Correlation test

\begin{tabular}{|c|c|c|c|}
\hline \multicolumn{4}{|c|}{ Correlations } \\
\hline & & INT & SPC \\
\hline \multirow{3}{*}{ INT } & Pearson Correlation & 1 & $.383^{*}$ \\
\hline & Sig. (2-tailed) & & .016 \\
\hline & $\mathrm{N}$ & 39 & 39 \\
\hline \multirow{3}{*}{ SPC } & Pearson Correlation & $.383^{*}$ & 1 \\
\hline & Sig. (2-tailed) & .016 & \\
\hline & $\mathrm{N}$ & 39 & 39 \\
\hline
\end{tabular}

A Bivariate correlation test was conducted as seen in the table 20 above. Correlation test was carried out to check if there is association between Intention to turn into using self-driving car (INT) and specification (SPC) of self-driving car at (0.05) level, findings are:

- The correlation between features (SPC) and intention (INT) is intermediate $=0.383$, i.e. $0.25 \leq r$ $<0.75$ and positive
The results show that there is an intermediate positive relationship between the constructs (Global Variables) along with intermediate correlation. So, the above suggested Hypotheses $\mathrm{H} 2$ is accepted.

Regression Test:

Regression test conducted to whether the specifications of self-driving car could predict the UAE people's intention to turn into using self-driving car. 
Intermediate positive correlation exists between the selfdriving car's specifications and the people's intention to turn into using self-driving car $(R=.383)$ and the regression model predicted $14 \%$ of the variance. In other words, UAE people's intention to turn into using self-driving car is intermediately predicted by self-driving car's specifications as seen in Table 21 below.

Table 21: Regression Model Summary

As seen in table 22below, the regression model can predict the dependent variable (INT) by checking the regression row and the (Sig) column it is clear that the statistical significance of the regression model that

\section{Model Summary}

\begin{tabular}{|c|c|c|c|c|c|c|c|c|c|}
\hline \multirow[b]{2}{*}{ Model } & \multirow[b]{2}{*}{$\mathrm{R}$} & \multirow[b]{2}{*}{ R Square } & \multirow{2}{*}{$\begin{array}{l}\text { Adjusted R } \\
\text { Square }\end{array}$} & \multirow{2}{*}{$\begin{array}{l}\text { Std. Error of } \\
\text { the Estimate }\end{array}$} & \multicolumn{5}{|c|}{ Change Statistics } \\
\hline & & & & & $\begin{array}{l}\text { R Square } \\
\text { Change }\end{array}$ & F Change & df1 & df2 & $\begin{array}{c}\text { Sig. F } \\
\text { Change }\end{array}$ \\
\hline 1 & $.383^{a}$ & .147 & .124 & 6.55839 & .147 & 6.376 & 1 & 37 & .016 \\
\hline \multicolumn{10}{|c|}{ a. Predictors: (Constant), SPC } \\
\hline & & & & b. Depender & Variable: I & & & & \\
\hline
\end{tabular}

was run; Here, $p<0.05$, and indicates that, overall, the regression model can significantly predicts the outcome variable.

Table 22: Analysis of Variance for intention to use self-driving car based on its specifications

\begin{tabular}{|c|c|c|c|c|c|c|}
\hline \multicolumn{7}{|c|}{ ANOVA $^{\mathrm{a}}$} \\
\hline \multirow{2}{*}{ Model } & Sum of Squares & df & Mean Square & F & Sig. \\
\hline \multirow{2}{*}{1} & Regression & 274.231 & 1 & 274.231 & 6.376 & $.016^{b}$ \\
\cline { 2 - 7 } & Residual & 1591.462 & 37 & 43.012 & & \\
\cline { 2 - 7 } & Total & 1865.692 & 38 & & & \\
\hline \multicolumn{7}{|c|}{ a. Dependent Variable: INT } \\
\hline \multicolumn{7}{|c|}{ b. Predictors: (Constant), SPC } \\
\hline
\end{tabular}

Also, Table 23 below shows that the for the independent variable (SPC), the probability for the $t$ statistic (2.525) for b coefficient is .016 which is less than the level of significance (.05). So, there is a statistically significant relationship between the specifications of the self-driving car and the intention to use that car. Therefore, $\mathrm{H} 2$ is accepted. Also, b coefficient that associated with SPC (.383) is positive and implies that the better the specifications of the selfdriving car the higher intention of the user to turn into using self-driving car.

Table 23: Coefficients of intention to use self-driving car based on its specifications

\begin{tabular}{|c|c|c|c|c|c|c|c|c|c|}
\hline \multicolumn{10}{|c|}{ Coefficients $^{\mathrm{a}}$} \\
\hline \multirow{2}{*}{ Model } & \multicolumn{2}{|c|}{$\begin{array}{c}\text { Unstandardized } \\
\text { Coefficients }\end{array}$} & \multirow{2}{*}{$\begin{array}{c}\begin{array}{c}\text { Standardized } \\
\text { Coefficients }\end{array} \\
\text { Beta }\end{array}$} & \multirow{2}{*}{$t$} & \multirow{2}{*}{ Sig. } & \multicolumn{2}{|c|}{$\begin{array}{c}95.0 \% \text { Confidence } \\
\text { Interval for B }\end{array}$} & \multicolumn{2}{|c|}{ Collinearity Statistics } \\
\hline & B & Std. Error & & & & $\begin{array}{l}\text { Lower } \\
\text { Bound }\end{array}$ & $\begin{array}{l}\text { Upper } \\
\text { Bound }\end{array}$ & Tolerance & VIF \\
\hline (Constant) & -4.342 & 15.039 & & -.289 & .774 & -34.813 & 26.130 & & \\
\hline SPC & .424 & .168 & .383 & 2.525 & .016 & .084 & .765 & 1.000 & 1.000 \\
\hline \multicolumn{10}{|c|}{ a. Dependent Variable: INT } \\
\hline
\end{tabular}

iii. Correlation test and Regression test to measure the relationship between self-driving car's features and people's intention to turn into using selfdriving car:

Q3: Does the self-driving car's features impact the UAE people's intention to turn into using self-driving car?

H3: There is significant association between self-driving car's features and the UAE people's intention to turn into using self-driving car.

H4: There is significant association between self-driving car's safety features and the UAE people's intention to turn into using self-driving car.
H5: There is significant association between self-driving car's performance features and the UAE people's intention to turn into using self-driving car.

H6: There is significant association between self-driving car's Ease of Use features and the UAE people's intention to turn into using self-driving car.

H7: There is significant association between self-driving car's Usefulness features and the UAE people's intention to turn into using self-driving car.

For this research question, global variables identified as following: 
FET: expected features of self-driving car

SFET: expected Safety features of self-driving car

PFET: expected Performance features of self-driving car
EFET: expected Ease of Use features of self-driving car BFET: expected Usefulness features of self-driving car INT: intention into using self-driving car Correlation Test:

Table 24: Correlation for features of self-driving car and intention to use the car

\begin{tabular}{|c|c|c|c|c|c|c|c|}
\hline \multicolumn{8}{|c|}{ Correlations } \\
\hline & & FET & SFET & PFET & EFET & BFET & INT \\
\hline \multirow{3}{*}{ FET } & Pearson Correlation & 1 & $.882^{* \star}$ & $.823^{* \star}$ & $.812^{\star \star}$ & $.939^{* \star}$ & $.856^{\star *}$ \\
\hline & Sig. (2-tailed) & & .000 & .000 & .000 & .000 & .000 \\
\hline & $N$ & 39 & 39 & 39 & 39 & 39 & 39 \\
\hline \multirow{3}{*}{ SFET } & Pearson Correlation & $.882^{\star \star}$ & 1 & $.676^{* *}$ & $.638^{* \star}$ & $.760^{\star \star}$ & $.741^{\star *}$ \\
\hline & Sig. (2-tailed) & .000 & & .000 & .000 & .000 & .000 \\
\hline & $\mathrm{N}$ & 39 & 39 & 39 & 39 & 39 & 39 \\
\hline \multirow{3}{*}{ PFET } & Pearson Correlation & $.823^{* \star}$ & $.676^{\star *}$ & 1 & $.556^{* *}$ & $.711^{\star \star}$ & $.686^{* x}$ \\
\hline & Sig. (2-tailed) & .000 & .000 & & .000 & .000 & .000 \\
\hline & $N$ & 39 & 39 & 39 & 39 & 39 & 39 \\
\hline \multirow{3}{*}{ EFET } & Pearson Correlation & $.812^{\star \star}$ & $.638^{* *}$ & $.556^{\star \star}$ & 1 & $.760^{* *}$ & $.787^{\star *}$ \\
\hline & Sig. (2-tailed) & .000 & .000 & .000 & & .000 & .000 \\
\hline & $\mathrm{N}$ & 39 & 39 & 39 & 39 & 39 & 39 \\
\hline \multirow{3}{*}{ BFET } & Pearson Correlation & $.939^{\star *}$ & $.760^{\star \star}$ & $.711^{\star *}$ & $.760^{* *}$ & 1 & $.772^{* *}$ \\
\hline & Sig. (2-tailed) & .000 & .000 & .000 & .000 & & .000 \\
\hline & $\mathrm{N}$ & 39 & 39 & 39 & 39 & 39 & 39 \\
\hline \multirow{3}{*}{ INT } & Pearson Correlation & $.856^{\star *}$ & $.741^{* *}$ & $.686^{\star \star}$ & $.787^{*}$ & $.772^{* \times}$ & 1 \\
\hline & Sig. (2-tailed) & .000 & .000 & .000 & .000 & .000 & \\
\hline & $\mathrm{N}$ & 39 & 39 & 39 & 39 & 39 & 39 \\
\hline
\end{tabular}

A Bivariate correlation test was conducted as seen in the table24. Correlation test was carried out to check if there is association between Intention to turn into using self-driving car (INT) and features (FET), safety features (SFET), performance features (PFET), ease of use features (EFET) and usefulness (BFET) of self-driving car at (0.01) level, findings are:

- The correlation between features (FET) and intention (INT) is strong $=0.856$, i.e. $0 \leqslant 75<1$ and positive

- The correlation between safety (SFET) and intention (INT) is intermediate $=0.741$, i.e. $0.25 r<0.75$ and positive

- The correlation between performance (PFET) and intention (INT) is intermediate $=0.686$, i.e. $0.25 \leq r$ $<0.75$ and positive

- The correlation between ease of use (EFET) and intention (INT) is strong $=0.787$, i.e. $0.75 \leq r<1$ and positive
- The correlation between usefulness (BFET) and intention (INT) is strong $=0.772$, i.e. $0.75 r<1$ and positive

The results show that there is a strong positive relationship between all of the constructs (Global Variables) along with strong correlation. So, the above suggested Hypotheses are all accepted, and all the null Hypotheses were rejected.

Regression Test:

Regression test conducted to whether the features of self-driving car could predict the UAE people's intention to turn into using self-driving car. Strong positive correlation exists between the selfdriving car's features and the people's intention to turn into using self-driving car $(R=.875)$ and the regression model predicted $76 \%$ of the variance. In other words, UAE people's intention to turn into using self-driving car is strongly predicted by self-driving car's features as seen in Table 25 below.

Table 25: Regression Model Summary

\begin{tabular}{|c|c|c|c|c|c|c|c|c|c|}
\hline \multicolumn{10}{|c|}{ Model Summary ${ }^{b}$} \\
\hline \multirow[b]{2}{*}{ Model } & \multirow[b]{2}{*}{$\mathrm{R}$} & \multirow[b]{2}{*}{ R Square } & \multirow{2}{*}{$\begin{array}{l}\text { Adjusted R } \\
\text { Square }\end{array}$} & \multirow{2}{*}{$\begin{array}{l}\text { Std. Error of } \\
\text { the Estimate }\end{array}$} & \multicolumn{5}{|c|}{ Change Statistics } \\
\hline & & & & & $\begin{array}{l}\text { R Square } \\
\text { Change }\end{array}$ & F Change & df1 & df2 & Sig. F Change \\
\hline 1 & $.875^{a}$ & .766 & .731 & 3.63367 & .766 & 21.660 & 5 & 33 & .000 \\
\hline \multicolumn{10}{|c|}{ a. Predictors: (Constant), BFET, PFET, EFET, SFET, FET } \\
\hline \multicolumn{10}{|c|}{ b. Dependent Variable: INT } \\
\hline
\end{tabular}


As seen in table 26below, the regression model can predict the dependent variable (INT) efficiently by checking the regression row and the (Sig) column it is clear that the statistical significance of the regression model that was run; Here, $p<0.05$, and indicates that, overall, the regression model can significantly predicts the outcome variable.

Table 26: Analysis of Variance for intention to use self-driving car based on

\begin{tabular}{|c|c|c|c|c|c|c|}
\hline \multicolumn{7}{|c|}{ ANOVA $^{\text {a }}$} \\
\hline \multirow{2}{*}{1} & Model & Sum of Squares & $\mathrm{df}$ & Mean Square & $\mathrm{F}$ & Sig. \\
\hline \multirow{2}{*}{1} & Regression & 1429.974 & 5 & 285.995 & 21.660 & $.000^{\mathrm{b}}$ \\
\cline { 2 - 7 } & Residual & 435.718 & 33 & 13.204 & & \\
\cline { 2 - 7 } & Total & 1865.692 & 38 & & & \\
\hline \multicolumn{7}{|c|}{ a. Dependent Variable: INT } \\
\hline \multicolumn{7}{|c|}{ b. Predictors: (Constant), BFET, PFET, EFET, SFET, FET }
\end{tabular}

Also, Table 27 below shows that the for the independent variable (FET), the probability for the $t$ statistic (10.054) for b coefficient is .000 which is less than the level of significance (.05). So, there is a statistically significant relationship between the perceived features of the self-driving car and the intention to use that car. Therefore, $\mathrm{H} 3$ is accepted. Also, b coefficient that associated with FET (.856) is positive and implies that the much excellent features of the self-driving car the higher intention of the user to turn into using self-driving car.

Table 27: Coefficients of intention to use self-driving car based on car's features

\begin{tabular}{|c|c|c|c|c|c|c|c|c|c|c|}
\hline \multicolumn{11}{|c|}{ Coefficients $^{a}$} \\
\hline & \multirow{2}{*}{ Model } & \multicolumn{2}{|c|}{$\begin{array}{l}\text { Unstandardized } \\
\text { Coefficients }\end{array}$} & \multirow{2}{*}{\begin{tabular}{|c|}
$\begin{array}{c}\text { Standardized } \\
\text { Coefficients }\end{array}$ \\
Beta
\end{tabular}} & \multirow{2}{*}{$\mathrm{t}$} & \multirow{2}{*}{ Sig. } & \multicolumn{2}{|c|}{$\begin{array}{l}95.0 \% \text { Confidence } \\
\text { Interval for B }\end{array}$} & \multicolumn{2}{|c|}{$\begin{array}{l}\text { Collinearity } \\
\text { Statistics }\end{array}$} \\
\hline & & B & Std. Error & & & & $\begin{array}{l}\text { Lower } \\
\text { Bound }\end{array}$ & $\begin{array}{l}\text { Upper } \\
\text { Bound }\end{array}$ & Tolerance & VIF \\
\hline \multirow{2}{*}{1} & (Constant) & -2.000 & 3.583 & & -.558 & .580 & -9.261 & 5.261 & & \\
\hline & FET & .334 & .033 & .856 & 10.054 & .000 & .267 & .401 & 1.000 & 1.000 \\
\hline
\end{tabular}

Also, Table 28below shows that the for the independent variable (SFET), the probability for the $t$ statistic (6.717) for b coefficient is .000 which is less than the level of significance (.05). So, there is a statistically significant relationship between the perceived features of the self-driving car and the intention to use that car. Therefore, $\mathrm{H} 4$ is accepted. Also, b coefficient that associated with FET (.741) is positive and implies that the much excellent Safety features of the self-driving car the higher intention of the user to turn into using self-driving car.

Table 28: Coefficients of intention to use self-driving car based on car's safety features

\begin{tabular}{|c|c|c|c|c|c|c|c|c|c|c|}
\hline \multicolumn{11}{|c|}{ Coefficients $^{a}$} \\
\hline & \multirow{2}{*}{ Model } & \multicolumn{2}{|c|}{$\begin{array}{l}\text { Unstandardized } \\
\text { Coefficients }\end{array}$} & \multirow{2}{*}{\begin{tabular}{|c} 
Standardized \\
Coefficients
\end{tabular}} & \multirow{2}{*}{$\mathrm{t}$} & \multirow{2}{*}{ Sig. } & \multicolumn{2}{|c|}{$\begin{array}{l}95.0 \% \text { Confidence } \\
\text { Interval for B }\end{array}$} & \multicolumn{2}{|c|}{$\begin{array}{l}\text { Collinearity } \\
\text { Statistics }\end{array}$} \\
\hline & & B & Std. Error & & & & $\begin{array}{l}\text { Lower } \\
\text { Bound }\end{array}$ & $\begin{array}{l}\text { Upper } \\
\text { Bound }\end{array}$ & Tolerance & VIF \\
\hline \multirow{2}{*}{1} & (Constant) & 8.419 & 3.817 & & 2.206 & .034 & .685 & 16.152 & & \\
\hline & \begin{tabular}{|l|} 
SFET \\
\end{tabular} & 1.146 & .171 & .741 & 6.717 & .000 & .800 & 1.491 & 1.000 & 1.000 \\
\hline \multicolumn{11}{|c|}{ a. Dependent Variable: INT } \\
\hline
\end{tabular}

Also, Table 29 below shows that the for the independent variable (PFET), the probability for the $t$ statistic (5.733) for b coefficient is .000 which is less than the level of significance (.05). So, there is a statistically significant relationship between the perceived features of the self-driving car and the intention to use that car. Therefore, $\mathrm{H} 5$ is accepted. Also, b coefficient that associated with FET (.686) is positive and implies that the much excellent Performance features of the self-driving car the higher intention of the user to turn into using self-driving car. 
Table 29: Coefficients of intention to use self-driving car based on car's Performance features

\begin{tabular}{|c|c|c|c|c|c|c|c|c|c|c|}
\hline \multicolumn{11}{|c|}{ Coefficients $^{a}$} \\
\hline & \multirow{2}{*}{ Model } & \multicolumn{2}{|c|}{$\begin{array}{l}\text { Unstandardized } \\
\text { Coefficients }\end{array}$} & \multirow{2}{*}{$\begin{array}{c}\text { Standardized } \\
\text { Coefficients } \\
\text { Beta }\end{array}$} & \multirow{2}{*}{$\mathrm{t}$} & \multirow{2}{*}{ Sig. } & \multicolumn{2}{|c|}{$\begin{array}{l}95.0 \% \text { Confidence } \\
\text { Interval for B }\end{array}$} & \multicolumn{2}{|c|}{$\begin{array}{c}\text { Collinearity } \\
\text { Statistics }\end{array}$} \\
\hline & & B & Std. Error & & & & $\begin{array}{l}\text { Lower } \\
\text { Bound }\end{array}$ & $\begin{array}{l}\text { Upper } \\
\text { Bound }\end{array}$ & Tolerance & VIF \\
\hline \multirow{2}{*}{1} & (Constant) & 14.471 & 3.427 & & 4.222 & .000 & 7.526 & 21.415 & & \\
\hline & PFET & 1.788 & .312 & .686 & 5.733 & .000 & 1.156 & 2.419 & 1.000 & 1.000 \\
\hline \multicolumn{11}{|c|}{ a. Dependent Variable: INT } \\
\hline
\end{tabular}

Also, Table 30below shows that the for the independent variable (EFET), the probability for the $t$ statistic (7.765) for b coefficient is .000 which is less than the level of significance (.05). So, there is a statistically significant relationship between the perceived features of the self-driving car and the

Table 30: Coefficients of intention to use self-driving car based on car's Ease of Use features

\begin{tabular}{|c|c|c|c|c|c|c|c|c|c|c|}
\hline \multicolumn{11}{|c|}{ Coefficients $^{a}$} \\
\hline & \multirow{2}{*}{ Model } & \multicolumn{2}{|c|}{$\begin{array}{l}\text { Unstandardized } \\
\text { Coefficients }\end{array}$} & \multirow{2}{*}{$\begin{array}{c}\text { Standardized } \\
\text { Coefficients }\end{array}$} & \multirow{2}{*}{$\mathrm{t}$} & \multirow{2}{*}{ Sig. } & \multicolumn{2}{|c|}{$\begin{array}{l}95.0 \% \text { Confidence } \\
\text { Interval for B }\end{array}$} & \multicolumn{2}{|c|}{$\begin{array}{l}\text { Collinearity } \\
\text { Statistics }\end{array}$} \\
\hline & & B & Std. Error & & & & $\begin{array}{l}\text { Lower } \\
\text { Bound }\end{array}$ & $\begin{array}{l}\text { Upper } \\
\text { Bound }\end{array}$ & Tolerance & VIF \\
\hline \multirow{2}{*}{1} & (Constant) & 5.242 & 3.711 & & 1.413 & .166 & -2.277 & 12.762 & & \\
\hline & EFET & 2.469 & .318 & .787 & 7.765 & .000 & 1.825 & 3.113 & 1.000 & 1.000 \\
\hline
\end{tabular}

Also, Table 31 below shows that the for the independent variable (BFET), the probability for the $t$ statistic (7.386) for $b$ coefficient is .000 which is less than the level of significance (.05). So, there is a statistically significant relationship between the perceived features of the self-driving car and the

intention to use that car. Therefore, $\mathrm{H} 7$ is accepted. Also, b coefficient that associated with FET (.772) is positive and implies that the much excellent Usefulness features of the self-driving car the higher intention of the user to turn into using self-driving car.

Table 31: Coefficients of intention to use self-driving car based on car's Usefulness features

\begin{tabular}{|c|c|c|c|c|c|c|c|c|c|c|}
\hline \multicolumn{11}{|c|}{ Coefficients $^{a}$} \\
\hline & \multirow{2}{*}{ Model } & \multicolumn{2}{|c|}{$\begin{array}{l}\text { Unstandardized } \\
\text { Coefficients }\end{array}$} & \multirow{2}{*}{$\begin{array}{c}\begin{array}{c}\text { Standardized } \\
\text { Coefficients }\end{array} \\
\text { Beta }\end{array}$} & \multirow{2}{*}{$\mathrm{t}$} & \multirow{2}{*}{ Sig. } & \multicolumn{2}{|c|}{$\begin{array}{c}95.0 \% \text { Confidence Interval } \\
\text { for B }\end{array}$} & \multicolumn{2}{|c|}{ Collinearity Statistics } \\
\hline & & B & Std. Error & & & & $\begin{array}{l}\text { Lower } \\
\text { Bound }\end{array}$ & $\begin{array}{l}\text { Upper } \\
\text { Bound }\end{array}$ & Tolerance & VIF \\
\hline \multirow{2}{*}{1} & (Constant) & 3.183 & 4.173 & & .763 & .450 & -5.272 & 11.637 & & \\
\hline & BFET & .771 & .104 & 772 & 7.386 & .000 & .560 & .983 & 1.000 & 1.000 \\
\hline \multicolumn{11}{|c|}{ a. Dependent Variable: INT } \\
\hline
\end{tabular}

iv. Frequency test to measure UAE people intention to turn into using self-driving car:

Q4: To what extent people in United Arab Emirates have the intention to turn into using self-driving car?

H8: People in United Arab Emirates have great intention to turn into using self-driving car.

Results presented that UAE people have high intention to turn into using self-driving car. Statistics represented the following as seen in Table 32 and Figure 10 below:
1. More than $71 \%$ of respondents are willing to pay even more for the self-driving car while around 13\% disagree about this.

2. $77 \%$ of respondents would recommend using selfdriving car.

3. More than $87 \%$ think that owning self-driving car is a good idea even that only $77 \%$ of respondents have the intention to buy self-driving car in the future while around $10 \%$ haven't the intention to buy such car in the future. 
From all above, people in UAE have great intention to turn into using self-driving car in the future. Thus, Hypothesis $\mathrm{H} 8$ is accepted.

Table 32: UAE people's intention to turn into using self-driving car

\begin{tabular}{|c|c|c|c|c|c|c|}
\hline & 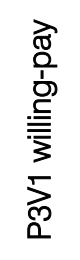 & 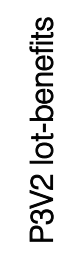 & 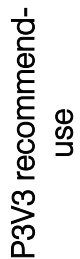 & 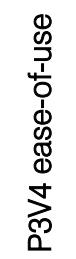 & 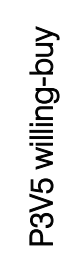 & 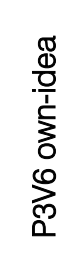 \\
\hline Strongly Disagree & 2.6 & 0 & 2.6 & 0 & 0 & 2.6 \\
\hline Disagree & 2.6 & 0 & 0 & 2.6 & 7.7 & 0 \\
\hline Slightly Disagree & 10.3 & 0 & 0 & 2.6 & 2.6 & 2.6 \\
\hline Neutral & 12.8 & 10.3 & 20.5 & 10.3 & 12.8 & 7.7 \\
\hline Slightly Agree & 25.6 & 20.5 & 15.4 & 23.1 & 23.1 & 25.6 \\
\hline Agree & 30.8 & 41 & 23.1 & 30.8 & 25.6 & 23.1 \\
\hline Agree Strongly & 15.4 & 28.2 & 38.5 & 30.8 & 28.2 & 38.5 \\
\hline
\end{tabular}

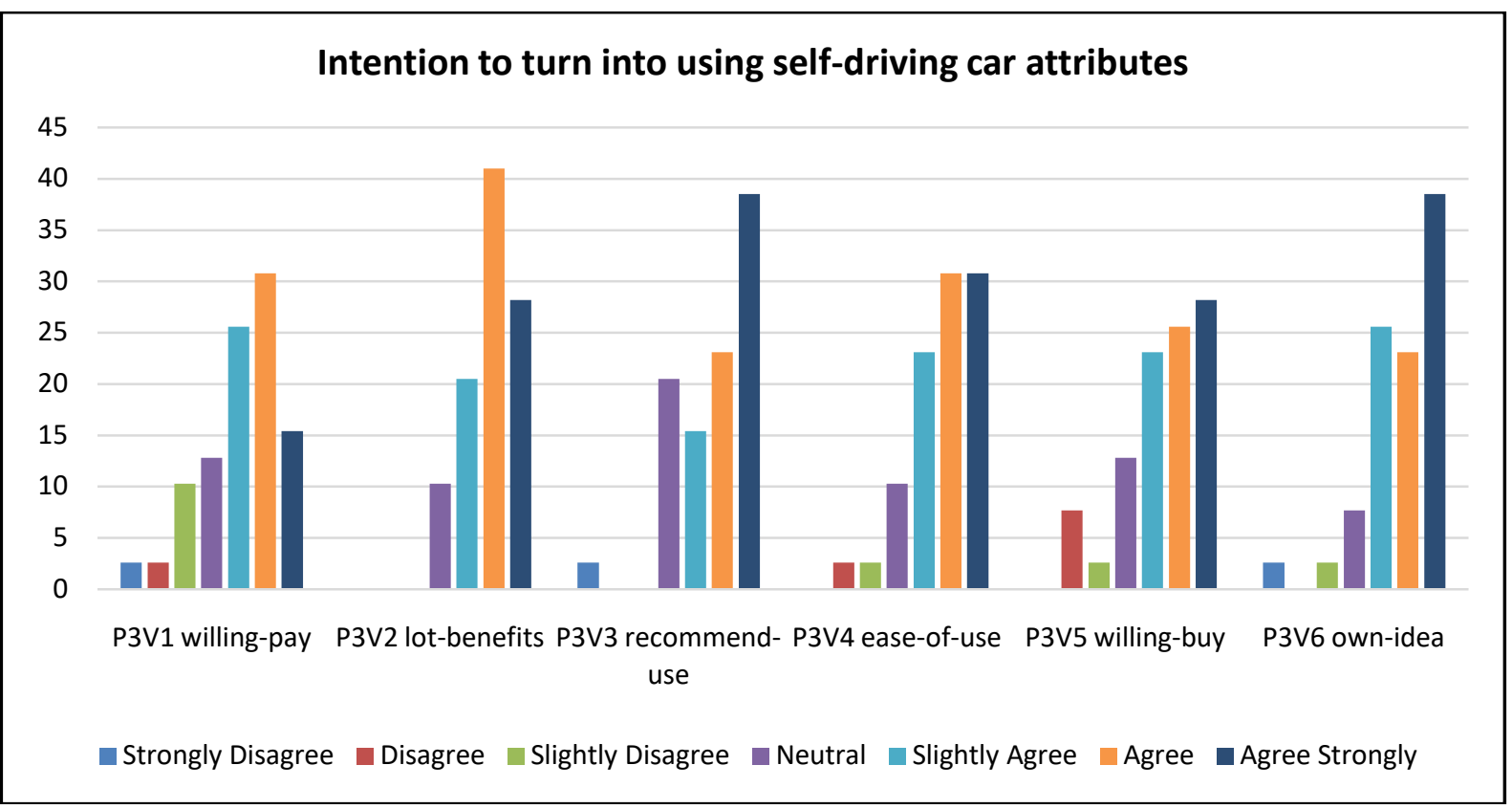

Figure 10: UAE people's intention to turn into using self-driving car

v. T-Test to investigate whether the gender factor have different impact on the intention to use selfdriving car:

Q5: Does the Gender factor have different impact on the intention to turn into using self-driving car?

H9: there is no significant difference between males and females in their intention to turn into using self-driving car.

T-Test conducted to compare the intention to turn into using self-driving car based on the gender. An independent samples test was carried out to compare the intention to turn into using self-driving car based on gender. As seen in table 33 and table 34 There is no significant difference in the intention between Male and Female, $\mathrm{t}(39)=-0.533, \mathrm{p}>0.05$, two tailed with Female $(M=34.1579, S D=7.80501)$ have slight higher intention to turn into using self-driving car than Male $(M=32.9500$, $S D=6.30351$ ). the magnitude of the difference in the means (mean difference 34.1579-32.9500 $=1.2079$, 95\% $\mathrm{Cl}$ : -5.79966 to 3.38387 ) was small (eta squared $=$ 0.0076). Since there is no significant difference in the intention between Male and Female to turn into using self-driving car, therefore, $\mathrm{H} 9$ is accepted. 
Table 33: Simple statistics of intention to turn into using self-driving car based on gender

\begin{tabular}{|c|c|c|c|c|c|}
\hline \multicolumn{9}{|c|}{ Group Statistics } \\
\hline \multirow{2}{*}{ INT } & Gender & N & Mean & Std. Deviation & Std. Error Mean \\
\cline { 2 - 6 } & Male & 20 & 32.9500 & 6.30351 & 1.40951 \\
\cline { 2 - 6 } & Female & 19 & 34.1579 & 7.80501 & 1.79059 \\
\hline
\end{tabular}

Table 34: Independent sample T test of intention to turn into using self-driving car based on gender

\begin{tabular}{|c|c|c|c|c|c|c|c|c|c|c|}
\hline \multicolumn{11}{|c|}{ Independent Samples Test } \\
\hline & & \multicolumn{2}{|c|}{$\begin{array}{c}\text { Levene's Test for } \\
\text { Equality of Variances }\end{array}$} & \multicolumn{7}{|c|}{ t-test for Equality of Means } \\
\hline & & \multirow[t]{2}{*}{$\mathrm{F}$} & \multirow[t]{2}{*}{ Sig. } & \multirow[t]{2}{*}{$\mathrm{t}$} & \multirow[t]{2}{*}{ df } & \multirow[t]{2}{*}{$\begin{array}{l}\text { Sig. (2- } \\
\text { tailed) }\end{array}$} & \multirow[t]{2}{*}{$\begin{array}{c}\text { Mean } \\
\text { Difference }\end{array}$} & \multirow[t]{2}{*}{$\begin{array}{l}\text { Std. Error } \\
\text { Difference }\end{array}$} & \multicolumn{2}{|c|}{$\begin{array}{l}95 \% \text { Confidence } \\
\text { Interval of the } \\
\text { Difference }\end{array}$} \\
\hline & & & & & & & & & Lower & Upper \\
\hline \multirow{2}{*}{ INT } & $\begin{array}{l}\text { Equal variances } \\
\text { assumed }\end{array}$ & .094 & .761 & -.533 & 37 & .597 & -1.20789 & 2.26620 & -5.79966 & 3.38387 \\
\hline & $\begin{array}{l}\text { Equal variances } \\
\text { not assumed }\end{array}$ & & & -.530 & 34.624 & .599 & -1.20789 & 2.27880 & -5.83590 & 3.42011 \\
\hline
\end{tabular}

vi. Anova test to investigate whether the Driving Experience factor have different impact on the H10: Driving Experience have positive impact on the intention to use self-driving car:

Q6: Does the Driving Experience factor have different impact on the intention to turn into using self-driving car?

Table 35: Descriptive statistics of UAE people's intention to turn into using self-driving car based on Driving Experience

\begin{tabular}{|c|c|c|c|c|c|c|c|c|}
\hline \multicolumn{9}{|c|}{ Descriptives } \\
\hline \multicolumn{9}{|c|}{ INT } \\
\hline & \multirow[t]{2}{*}{$\mathrm{N}$} & \multirow[t]{2}{*}{ Mean } & \multirow{2}{*}{$\begin{array}{c}\text { Std. } \\
\text { Deviation }\end{array}$} & \multirow[t]{2}{*}{ Std. Error } & \multicolumn{2}{|c|}{$\begin{array}{l}\text { 95\% Confidence Interval for } \\
\text { Mean }\end{array}$} & \multirow[t]{2}{*}{ Minimum } & \multirow[t]{2}{*}{ Maximum } \\
\hline & & & & & Lower Bound & Upper Bound & & \\
\hline Never & 4 & 33.2500 & 5.31507 & 2.65754 & 24.7925 & 41.7075 & 27.00 & 40.00 \\
\hline Less than 5 years & 5 & 35.4000 & 5.54977 & 2.48193 & 28.5090 & 42.2910 & 28.00 & 42.00 \\
\hline $5-9$ & 2 & 39.5000 & 3.53553 & 2.50000 & 7.7345 & 71.2655 & 37.00 & 42.00 \\
\hline $10-14$ & 6 & 35.0000 & 9.01110 & 3.67877 & 25.5434 & 44.4566 & 20.00 & 42.00 \\
\hline $15-20$ & 13 & 33.1538 & 8.47394 & 2.35025 & 28.0331 & 38.2746 & 14.00 & 42.00 \\
\hline More than 20 years & 9 & 30.8889 & 5.13431 & 1.71144 & 26.9423 & 34.8355 & 21.00 & 36.00 \\
\hline Total & 39 & 33.5385 & 7.00694 & 1.12201 & 31.2671 & 35.8098 & 14.00 & 42.00 \\
\hline
\end{tabular}

From table 36 below, it is clear that there are no statistically differences between the groups as a whole since the sig $>0.05$.

Table 36: Analysis of variance for intention to turn into using self-driving car based on Driving Experience

\begin{tabular}{|c|c|c|c|c|c|}
\hline \multicolumn{7}{|c|}{ ANOVA } \\
\hline \multicolumn{7}{|c|}{ INT } \\
\hline & Sum of Squares & df & Mean Square & F & Sig. \\
\hline Between Groups & 166.661 & 5 & 33.332 & .647 & .665 \\
\hline Within Groups & 1699.031 & 33 & 51.486 & & \\
\hline Total & 1865.692 & 38 & & & \\
\hline
\end{tabular}

One-way between groups analysis of variance was conducted to explore the impact of Driving Experience on the intention to turn into self-driving car. Participant were divided into six groups as the following (Never, Less than 5, 5-9, 10-14, 15-20, More than 20). We can see that the significance values $0.998,0.913$, $0.999,0.994,0.983,0.991,0.867,0.971,0.850,0.645$, $0.995,0.883,0.997$ and 1.000 (i.e., $p=$ values 0.998 ,
$0.913,0.999,0.994,0.983,0.991,0.867,0.971,0.850$ $0.645,0.995,0.883,0.997$ and 1.000 ) which is above 0.05 as seen in table 37 below. Therefore, there is no statistically significant difference in the rating of intention to turn into using self-driving car based on the Driving Experience of the respondents. Thus, hypothesis $\mathrm{H} 10$ is rejected. 
Table 37: Multiple comparisons for the intention to turn into using self-driving car based on Driving Experience

\begin{tabular}{|c|c|c|c|c|c|c|}
\hline \multicolumn{7}{|c|}{ Multiple Comparisons } \\
\hline \multicolumn{7}{|c|}{ Dependent Variable: INT } \\
\hline \multicolumn{7}{|c|}{ Tukey HSD } \\
\hline \multirow{2}{*}{$\begin{array}{l}\text { (I) Driving } \\
\text { Experience }\end{array}$} & \multirow{2}{*}{$\begin{array}{l}\text { (J) Driving } \\
\text { Experience }\end{array}$} & \multirow{2}{*}{$\begin{array}{c}\text { Mean } \\
\text { Difference } \\
(I-J)\end{array}$} & \multirow{2}{*}{$\begin{array}{l}\text { Std. } \\
\text { Error }\end{array}$} & \multirow{2}{*}{ Sig. } & \multicolumn{2}{|c|}{ 95\% Confidence Interval } \\
\hline & & & & & Lower Bound & Upper Bound \\
\hline \multirow{5}{*}{ Never } & Less than 5 years & -2.15000 & 4.81338 & .998 & -16.7034 & 12.4034 \\
\hline & $5-9$ & -6.25000 & 6.21404 & .913 & -25.0384 & 12.5384 \\
\hline & $10-14$ & -1.75000 & 4.63168 & .999 & -15.7540 & 12.2540 \\
\hline & $15-20$ & .09615 & 4.10267 & 1.000 & -12.3084 & 12.5007 \\
\hline & More than 20 years & 2.36111 & 4.31185 & .994 & -10.6759 & 15.3981 \\
\hline \multirow{5}{*}{ Less than 5 years } & Never & 2.15000 & 4.81338 & .998 & -12.4034 & 16.7034 \\
\hline & $5-9$ & -4.10000 & 6.00334 & .983 & -22.2513 & 14.0513 \\
\hline & $10-14$ & .40000 & 4.34490 & 1.000 & -12.7369 & 13.5369 \\
\hline & $15-20$ & 2.24615 & 3.77592 & .991 & -9.1705 & 13.6628 \\
\hline & More than 20 years & 4.51111 & 4.00222 & .867 & -7.5897 & 16.6120 \\
\hline \multirow{5}{*}{$5-9$} & Never & 6.25000 & 6.21404 & .913 & -12.5384 & 25.0384 \\
\hline & Less than 5 years & 4.10000 & 6.00334 & .983 & -14.0513 & 22.2513 \\
\hline & $10-14$ & 4.50000 & 5.85866 & .971 & -13.2138 & 22.2138 \\
\hline & $15-20$ & 6.34615 & 5.45008 & .850 & -10.1323 & 22.8246 \\
\hline & More than 20 years & 8.61111 & 5.60924 & .645 & -8.3486 & 25.5708 \\
\hline \multirow{5}{*}{$10-14$} & Never & 1.75000 & 4.63168 & .999 & -12.2540 & 15.7540 \\
\hline & Less than 5 years & -.40000 & 4.34490 & 1.000 & -13.5369 & 12.7369 \\
\hline & $5-9$ & -4.50000 & 5.85866 & .971 & -22.2138 & 13.2138 \\
\hline & $15-20$ & 1.84615 & 3.54139 & .995 & -8.8613 & 12.5536 \\
\hline & More than 20 years & 4.11111 & 3.78175 & .883 & -7.3231 & 15.5453 \\
\hline \multirow{5}{*}{$15-20$} & Never & -.09615 & 4.10267 & 1.000 & -12.5007 & 12.3084 \\
\hline & Less than 5 years & -2.24615 & 3.77592 & .991 & -13.6628 & 9.1705 \\
\hline & $5-9$ & -6.34615 & 5.45008 & .850 & -22.8246 & 10.1323 \\
\hline & $10-14$ & -1.84615 & 3.54139 & .995 & -12.5536 & 8.8613 \\
\hline & More than 20 years & 2.26496 & 3.11144 & .977 & -7.1426 & 11.6725 \\
\hline \multirow{5}{*}{ More than 20 years } & Never & -2.36111 & 4.31185 & .994 & -15.3981 & 10.6759 \\
\hline & Less than 5 years & -4.51111 & 4.00222 & .867 & -16.6120 & 7.5897 \\
\hline & $5-9$ & -8.61111 & 5.60924 & .645 & -25.5708 & 8.3486 \\
\hline & $10-14$ & -4.11111 & 3.78175 & .883 & -15.5453 & 7.3231 \\
\hline & $15-20$ & -2.26496 & 3.11144 & .977 & -11.6725 & 7.1426 \\
\hline
\end{tabular}

vii. Correlation test to investigate there is association between Education Level and the intention to turn into using self-driving car:

Q7: Does the Education Level factor associated with the intention to turn into using self-driving car?

H11: Level of Education is not associated with the intention to turn into using self-driving car.

A Bivariate correlation test was conducted as seen in the table 38below. Correlation test was carried out to check if there is association between Intention to turn into using self-driving car (INT) and the Education level, test presented that:
- The correlation between Education Level and intention to turn into using self-driving car (INT) is weak and positive $=0.175$, i.e. $0<r<0.25$ and positive. Therefore, hypothesis $\mathrm{H} 11$ is rejected. 
Table 38: Correlation for Education Level and intention to use the car

\begin{tabular}{|c|c|c|c|}
\hline \multicolumn{4}{|c|}{ Correlations } \\
\hline \multirow{3}{*}{ Education } & Pearson Correlation & Education & INT \\
\cline { 2 - 4 } & Sig. (2-tailed) & 1 & .175 \\
\cline { 2 - 4 } & $\mathrm{N}$ & 39 & .287 \\
\hline \multirow{3}{*}{ INT } & Pearson Correlation & .175 & 39 \\
\cline { 2 - 4 } & Sig. (2-tailed) & .287 & 1 \\
\cline { 2 - 4 } & $\mathrm{N}$ & 39 & 39 \\
\hline
\end{tabular}

viii. Chi-squared test to investigate whether there is association between gender and Driving Experience:

H12: there is significant association between gender and driving experience.

The sample size is less than 40 , i.e. 39 so the smallest expected frequency is at least 5. Chi-Square test can be used to compare if there is an observed frequency distribution with an expected frequency distribution. Chi-Square test will be used to compare if there is observed frequency between driving experience and gender within the population.

Table 39 displays how gender is associated with driving experience.

Table 39: Crosstabs (Gender*Driving Experience)

\begin{tabular}{|c|c|c|c|c|c|c|c|c|c|}
\hline \multicolumn{10}{|c|}{ Gender * Driving Experience Crosstabulation } \\
\hline & & & \multicolumn{6}{|c|}{ Driving Experience } & \multirow[b]{2}{*}{ Total } \\
\hline & & & Never & $\begin{array}{l}\text { Less than } 5 \\
\text { years }\end{array}$ & $5-9$ & $10-14$ & $15-20$ & $\begin{array}{c}\text { More than } 20 \\
\text { years }\end{array}$ & \\
\hline \multirow{8}{*}{ Gender } & \multirow{4}{*}{ Male } & Count & 0 & 0 & 1 & 3 & 8 & 8 & 20 \\
\hline & & $\%$ within Gender & $0.0 \%$ & $0.0 \%$ & $5.0 \%$ & $15.0 \%$ & $40.0 \%$ & $40.0 \%$ & $100.0 \%$ \\
\hline & & $\begin{array}{c}\text { \% within Driving } \\
\text { Experience }\end{array}$ & $0.0 \%$ & $0.0 \%$ & $50.0 \%$ & $50.0 \%$ & $61.5 \%$ & $88.9 \%$ & $51.3 \%$ \\
\hline & & $\%$ of Total & $0.0 \%$ & $0.0 \%$ & $2.6 \%$ & $7.7 \%$ & $20.5 \%$ & $20.5 \%$ & $51.3 \%$ \\
\hline & \multirow{4}{*}{ Female } & Count & 4 & 5 & 1 & 3 & 5 & 1 & 19 \\
\hline & & $\%$ within Gender & $21.1 \%$ & $26.3 \%$ & $5.3 \%$ & $15.8 \%$ & $26.3 \%$ & $5.3 \%$ & $100.0 \%$ \\
\hline & & $\begin{array}{c}\text { \% within Driving } \\
\text { Experience }\end{array}$ & $100.0 \%$ & $100.0 \%$ & $50.0 \%$ & $50.0 \%$ & $38.5 \%$ & $11.1 \%$ & $48.7 \%$ \\
\hline & & $\%$ of Total & $10.3 \%$ & $12.8 \%$ & $2.6 \%$ & $7.7 \%$ & $12.8 \%$ & $2.6 \%$ & $48.7 \%$ \\
\hline \multirow{4}{*}{\multicolumn{2}{|c|}{ Total }} & Count & 4 & 5 & 2 & 6 & 13 & 9 & 39 \\
\hline & & $\%$ within Gender & $10.3 \%$ & $12.8 \%$ & $5.1 \%$ & $15.4 \%$ & $33.3 \%$ & $23.1 \%$ & $100.0 \%$ \\
\hline & & $\begin{array}{l}\text { \% within Driving } \\
\text { Experience }\end{array}$ & $100.0 \%$ & $100.0 \%$ & $100.0 \%$ & $100.0 \%$ & $100.0 \%$ & $100.0 \%$ & $100.0 \%$ \\
\hline & & $\%$ of Total & $10.3 \%$ & $12.8 \%$ & $5.1 \%$ & $15.4 \%$ & $33.3 \%$ & $23.1 \%$ & $100.0 \%$ \\
\hline
\end{tabular}

When interpreting results from table 40 below, quoted in this form. Since $p$ is less than 0.05 then there results of Pearson Chi-Square row shows that $\times(2)=$ 15.121, corresponding to $p<0.05$ (note: the Asymptotic Significance (2-sided) value in this row, 0.010, is the $p$ value rounded to 5 decimal places and should not be is an evidence of strong relationship between the gender and driving experience. This indicates that there is statistically significant association between Gender and Driving Experience.

Table 40: Chi-Square tests

\begin{tabular}{|c|c|c|c|}
\hline \multicolumn{4}{|c|}{ Chi-Square Tests } \\
\hline & Value & df & $\begin{array}{c}\text { Asymptotic } \\
\text { Significance (2-sided) }\end{array}$ \\
\hline Pearson Chi-Square & $15.121^{\text {a }}$ & 5 & .010 \\
\hline Likelihood Ratio & 19.347 & 5 & .002 \\
\hline Linear-by-Linear Association & 13.895 & 1 & .000 \\
\hline N of Valid Cases & 39 & & \\
\hline a. 10 cells (83.3\%) have expected count less than 5. The minimum expected count is .97. \\
\hline
\end{tabular}

Phi and Cramer's are both tests of the strength of association. From table 41 below, we can see that the strength of the association between variables is moderate and significant. $P$ is less than 0.05 then hypothesis $\mathrm{H} 12$ is accepted. 
Table 41: Symmetric Measure to examine strength of association

\begin{tabular}{|c|c|c|c|}
\hline \multicolumn{3}{|c|}{ Symmetric Measures } \\
\hline \multicolumn{2}{|c|}{} & Value & $\begin{array}{c}\text { Approximate } \\
\text { Significance }\end{array}$ \\
\hline \multirow{2}{*}{ Nominal by Nominal } & Phi & .623 & .010 \\
\cline { 2 - 4 } & Cramer's V & .623 & .010 \\
\hline \multicolumn{2}{|c|}{ N of Valid Cases } & 39 & \\
\hline
\end{tabular}

\section{FINDINGS}

Statistical Analysis conducted in previous section in order to answer research questions as well as examining hypothesis, table below present whether the hypothesis accepted or rejected:

Table 42: Findings of research questions and related hypothesis

\begin{tabular}{|c|c|}
\hline Research Question & Related Hypothesis \\
\hline $\begin{array}{l}\text { Q1: To what extent UAE people care about } \\
\text { specifications of the self-driving car? }\end{array}$ & $\begin{array}{l}\text { H1: UAE people highly care about the specification of } \\
\text { self-driving car(Accepted) }\end{array}$ \\
\hline $\begin{array}{c}\text { Q2: Does the specifications of the self-driving car } \\
\text { impact the UAE people's intention to turn into using } \\
\text { self-driving car? }\end{array}$ & $\begin{array}{l}\text { H2: There is significant association between self-driving } \\
\text { car's specifications and the UAE people's intention to } \\
\text { turn into using self-driving car.(Accepted) }\end{array}$ \\
\hline \multirow{5}{*}{$\begin{array}{l}\text { Q3: Does the self-driving car's features impact the UAE } \\
\text { people's intention to turn into using self-driving car? }\end{array}$} & $\begin{array}{l}\text { H3: There is significant association between self-driving } \\
\text { car's features and the UAE people's intention to turn } \\
\text { into using self-driving car.(Accepted) }\end{array}$ \\
\hline & $\begin{array}{l}\text { H4: There is significant association between self-driving } \\
\text { car's safety features and the UAE people's intention to } \\
\text { turn into using self-driving car. (Accepted) }\end{array}$ \\
\hline & $\begin{array}{l}\text { H5: There is significant association between self-driving } \\
\text { car's performance features and the UAE people's } \\
\text { intention to turn into using self-driving car.(Accepted) }\end{array}$ \\
\hline & $\begin{array}{l}\text { H6: There is significant association between self-driving } \\
\text { car's Ease of Use features and the UAE people's } \\
\text { intention to turn into using self-driving car.(Accepted) }\end{array}$ \\
\hline & $\begin{array}{l}\text { H7: There is significant association between self-driving } \\
\text { car's Usefulness features and the UAE people's } \\
\text { intention to turn into using self-driving car.(Accepted) }\end{array}$ \\
\hline $\begin{array}{l}\text { Q4: To what extent people in United Arab Emirates } \\
\text { have the intention to turn into using self-driving car? }\end{array}$ & $\begin{array}{l}\text { H8: People in United Arab Emirates have great } \\
\text { intention to turn into using self-driving car.(Accepted) }\end{array}$ \\
\hline
\end{tabular}

Table 43: Findings of demographic questions and related hypothesis

\begin{tabular}{|c|c|}
\hline Demographic Questions & Related Hypothesis \\
\hline $\begin{array}{l}\text { Q5: Does the Gender factor have different impact on } \\
\text { the intention to turn into using self-driving car? }\end{array}$ & $\begin{array}{c}\text { H9: there is no significant difference between males } \\
\text { and females in their intention to turn into using self- } \\
\text { driving car.(Accepted) }\end{array}$ \\
\hline $\begin{array}{c}\text { Q6: Does the Driving Experience factor have different } \\
\text { impact on the intention to turn into using self-driving } \\
\text { car? }\end{array}$ & $\begin{array}{l}\text { H10: Driving Experience have positive impact on the } \\
\text { intention to turn into using self-driving car.(Rejected) }\end{array}$ \\
\hline $\begin{array}{l}\text { Q7: Does the Education Level factor associated with } \\
\text { the intention to turn into using self-driving car? }\end{array}$ & $\begin{array}{l}\text { H11: Level of Education is not associated with the } \\
\text { intention to turn into using self-driving car.(Rejected) }\end{array}$ \\
\hline $\begin{array}{l}\text { Q8: Does the Gender and Driving Experience } \\
\text { associated? }\end{array}$ & $\begin{array}{l}\text { H112: there is significant association between gender } \\
\text { and driving experience.(Accepted) }\end{array}$ \\
\hline
\end{tabular}


Statistical Analysis conducted as well for construct and scale validity; it was found that the there is no common bias in the collected data and the reliability test presented high score of Cronbach's Alpha which indicated high degree of reliability.

Univariate statistical test carried out for exploring frequencies and description purposes and results reported in previous section.

\section{Vili. Discussion}

In this research paper, Technology Acceptance Model modified by the author of this research paper to include additional constructs. The aim of this research paper to investigate the validity of the modified model in case for the acceptance of self-driving car in United Arab Emirates as the research main purpose is to investigate the intention of UAE people to turn into using self-driving car.

Statistical tests for answering first research question presented that UAE people highly care about the specifications of self-driving car. Responses showed that each of the specifications is important, but the most important specifications are safety, luxury, system, wheels and car's outside look. This result indicated that people are in UAE become more aware about their rights as customers to know about the product's specifications. People as well become more knowledgeable about the importance of each of the specifications of the self-driving car.

Results from statistical tests for answering second research question presented that self-driving car's specification is associated with the intention to turn into using self-driving car.

Results from statistical tests for answering third research question presented that self-driving car's features have strong positive impact on the UAE people's intention to turn into using self-driving car. This result is compatible with the Technology Acceptance Model that was introduced by Davis as stated by Paul Legrisa, John Inghamb, Pierre Collerettec, (2003). The Ease of Use features are strongly associated with the UAE people's intention to turn into using self-driving car. Results presented as well that the Usefulness features are strongly associated with the UAE people's intention to turn into using self-driving car. These results are consistent with the Technology acceptance Model. Author of this research paper investigated Safety features and performance features effects, and results presented that both of the defined features strongly associated with the intention to turn into using selfdriving car. Hence, self-driving car's features are strongly associated with the intention to turn into using self-driving car.The features of self-driving car have stronger impact on the intention to turn into using selfdriving car than the specification does.
Fourth research question results presented that people in United Arab Emirates have high intention to turn into using self-driving car as results showed that people are willing to pay even more for the self-driving car, they would recommend using self-driving car for others and they think that owning such car is a good idea. This Result is consistent and compatible with the Technology Acceptance Model as the features of selfdriving car positively impacted the people's intention to use the car.

Statistical tests conducted to answer fifth research question and results showed that there is no significant difference in the intention between Male and Female to turn into using self-driving car. Therefore, the gender factor has no impact on the intention to turn into using self-driving car. Statistical tests for answering sixth research question presented that Driving Experience as well has no impact on the intention to turn into usingself-driving car.

Seventh research question results showed that the Education Level slightly impact the people's intention to turn into using-self-driving car. Hence from all above statistical experiments conducted, the features as well as specifications of self-driving car is strongly associated with the intention to turn into using the car, hence the features and specifications of self-driving car impacted UAE people's intention to accept and turn into using such car and this result consistent and compatible with the Technology Acceptance Mode. Below is the updated conceptual research model. 


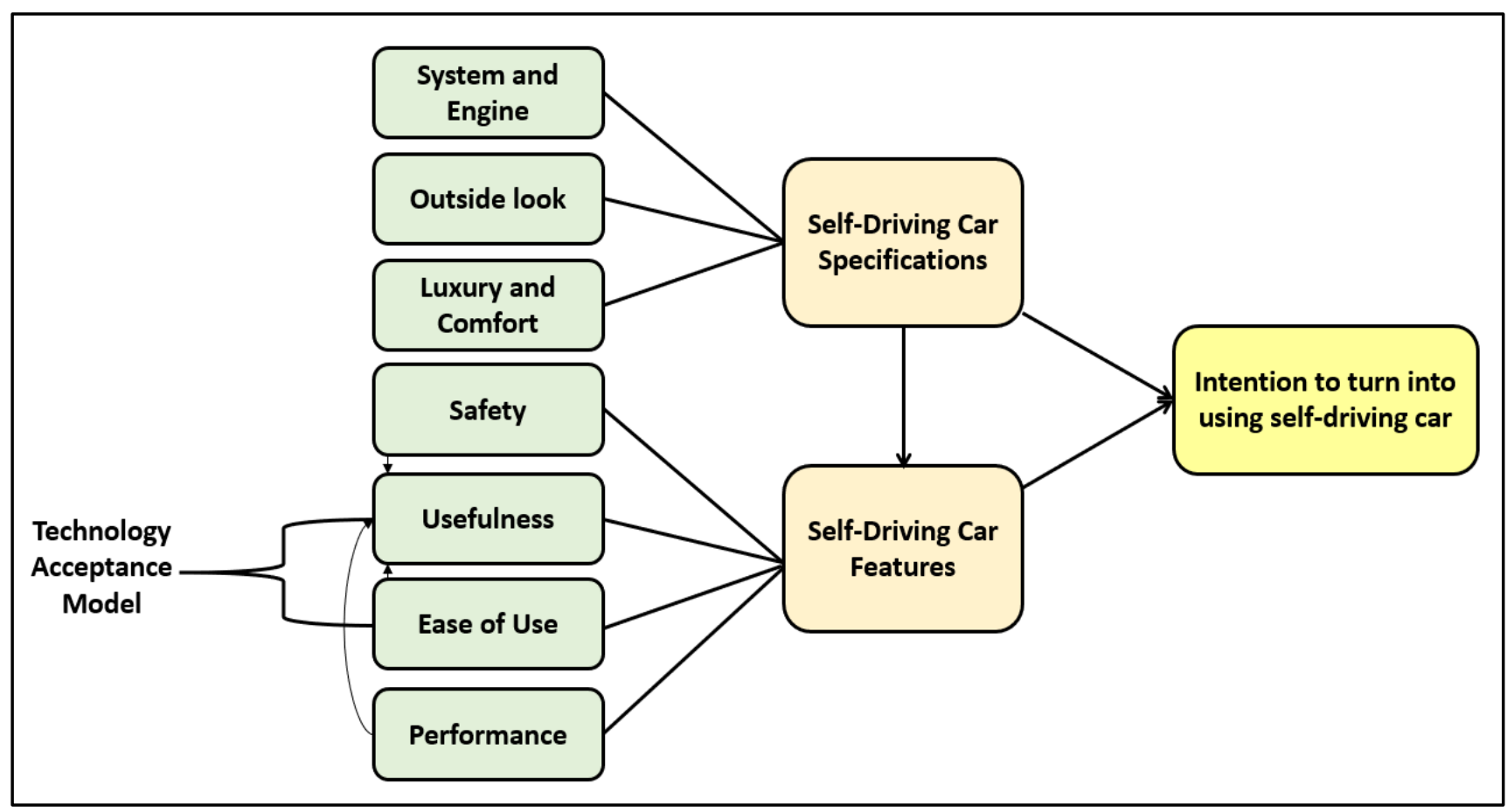

Figure 11: Adjusted conceptual model for research

Figure 11 above illustrated findings of this research paper, i.e. both the specifications of selfdriving car as well as the features impacted the intention to turn into using self-driving car. The features of selfdriving car have stronger impact on the intention to turn into using self-driving car than the specification does.

\section{iX. Conclusion}

The emergence of self-driving cars has raised the interest of the media as well as individuals in it and how reliable and what benefits the user may get when using this type of car. Although the self-driving car may provide huge benefits to the user compared to the traditional car that the user drive, the people perception to turn into using this type of car may vary as some users prefer to engage in driving by themselves. This research paper aim to explore UAE people's intention to turn into using self-driving car. To explore the research aim, based upon standard Technology Acceptance Model (TAM), author of this research paper adjusted TAM by adding new constructs. Quantitative methodology followed in this research paper and questionnaire was prepared and sent to respondents i.e. people live in UAE. Results presented that UAE people have high intention to turn into using self-driving car. Results presented as well that both specifications and features of self-driving car have great impact on people's intention to use the car and this result consistent with TAM. It is recommended for future research to investigate the infrastructure requirements for the adoption of self-driving car, and the impacts of the adoption of self-driving car as well.

\section{References Références Referencias}

1. Brandon Schoettle and Michael Sivak, 2014. A SURVEY OF PUBLIC OPINION ABOUT AUTONOMOUS AND SELF-DRIVING VEHICLES IN THE U.S., THE U.K., AND AUSTRALIA. The University of Michigan Transportation Research Institute. UMTRI-2014-21.

2. Brandon Schoettle and Michael Sivak, 2015. A PRELIMINARY ANALYSIS OF REAL-WORLD CRASHES INVOLVING SELF-DRIVING VEHICLES. The University of Michigan Transportation Research Institute. UMTRI-2015-34.

3. Michael A. Nees, 2016. Acceptance of Self-driving Cars: An Examination of Idealized versus Realistic Portrayals with a Self-driving Car Acceptance Scale. Lafayette College, Easton, PA.

4. Daniel Howard and Danielle Dai, 2013. Public Perceptions of Self-driving Cars: The Case of Berkeley, California. University of California, Berkeley - Department of City and Regional Planning.

5. MatjažKnez, MatevžObrecht, 2019. How can people be convinced to buy electric cars? - case of Slovenia. PRODUCTION ENGINEERING ARCHIVES 21 (2018) 24-27. ISSN2353-7779

6. Ward C., Raue M., Lee C., D'Ambrosio L., Coughlin J.F. 2017 Acceptance of Automated Driving Across Generations: The Role of Risk and Benefit Perception, Knowledge, and Trust. In: Kurosu M. (eds) Human-Computer Interaction. User Interface Design, Development and Multimodality. HCl 2017. 
Lecture Notes in Computer Science, vol 10271. Springer, Cham

7. Yu Shi; Jiefeng Chen; Qi Li, 2017. The Effects of Self-Driving Vehicles on Traffic Capacity. UMAP Journal. Fall2017, Vol. 38 Issue 3, p323-346. 24p

8. M. König, L. Neumayr, 2016. Users' resistance towards radical innovations: The case of the selfdriving car. Transportation Research Part F 44 (2017) 42-52

9. Frank Douma and Sarah AuePalodichuk, 2012.Criminal Liability Issues Created by Autonomous Vehicles. Santa Clara Law Review, 52, 1157

10. Pawel Gora and Inga Rüba, 2016. Traffic models for self-driving connected cars. Transportation Research Procedia 14 (2016) 2207 - 2216.

11. National Highway Traffic Safety Administration of the United states Department of Transportation, NHTSA, 2013. http://www.nhtsa.gov/staticfiles/ rulemaking/pdf/Automated_Vehicles_Policy.pdf, last accessed: 12.6.2019
12. Corey D.Harper, Chris T.Hendrickson, Sonia Mangones, Constantine Samaras, 2016. Estimating potential increases in travel with autonomous vehicles for the non-driving, elderly and people with travel-restrictive medical conditions. Transportation Research Part C: Emerging Technologies. Volume 72, November 2016, Pages 1-9

13. Nigel Norris, 1997. Error, bias and validity in qualitative research, Educational Action Research, 5:1, 172-176, DOI: 10.1080/09650799700200020. Published online 03 Sep 2007.

14. Haradhan Kumar MOHAJAN, 2017. TWO CRITERIA FOR GOOD MEASUREMENTS IN RESEARCH: VALIDITY AND RELIABILITY. Annals of SpiruHaret University. Economic Series.Issue No: 4,Page Range: 59-82

15. Paul Legrisa, John Inghamb, Pierre Collerettec, 2003. Why do people use information technology? A critical review of the technology acceptance model. Information \& Management. Volume 40, Issue 3, January 2003, Pages 191-204

\section{Appendices}

APPENDIX A

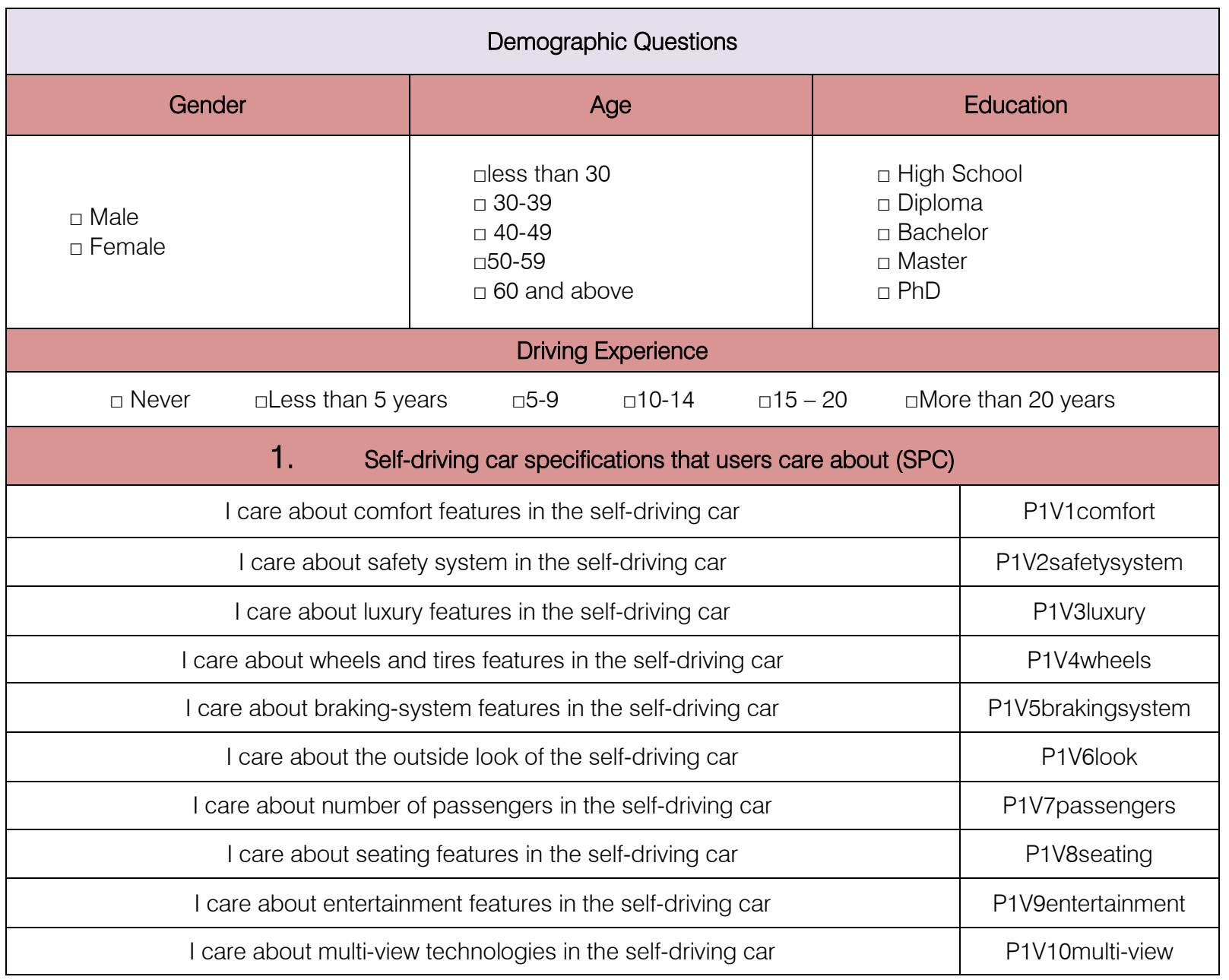




\begin{tabular}{|c|c|c|}
\hline & I care about car engine features in the self-driving car & P1V11engine \\
\hline & I care about speed features in the self-driving car & P1V12speed \\
\hline & I prefer complete autonomous driving system in the self-driving car & $\begin{array}{l}\text { P1V13complete- } \\
\text { autonomous }\end{array}$ \\
\hline & I prefer partial autonomous driving system in the self-driving car & $\begin{array}{l}\text { P1V14partial- } \\
\text { autonomous }\end{array}$ \\
\hline \multicolumn{3}{|c|}{ 2. Perceived self-driving car features (FET) } \\
\hline \multirow{5}{*}{ 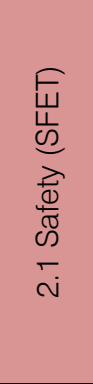 } & 2.1 I believe self-driving car is safe & P2V1safe \\
\hline & 2.1 I believe self-driving car will never exceed speed limit & P2V2speed-limit \\
\hline & 2.1 I believe self-driving car will never break road rules & P2V3road-rules \\
\hline & 2.1 I believe self-driving car will reduce the incident of car accident & $\begin{array}{l}\text { P2V4reduce- } \\
\text { accidents }\end{array}$ \\
\hline & $\begin{array}{l}2.1 \text { I believe that the safety system in the self-driving car will encourage me to } \\
\text { use the car }\end{array}$ & $\begin{array}{l}\text { P2V5safety- } \\
\text { encourage }\end{array}$ \\
\hline \multirow{3}{*}{ 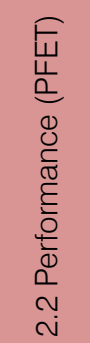 } & 2.2 Self-driving car efficient in reaching destination fast & P2V6reach-destination \\
\hline & 2.2 Self-driving car will not consume much fuel & P2V7fuel \\
\hline & $\begin{array}{c}2.2 \text { I believe that the performance of the self-driving car will encourage me to } \\
\text { use the car. }\end{array}$ & $\begin{array}{l}\text { P2V8performane- } \\
\text { encourage }\end{array}$ \\
\hline \multirow{3}{*}{ 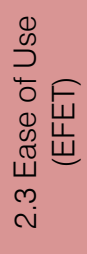 } & 2.3 I believe that self-driving car is easy to use & P2V9easy-to-use \\
\hline & 2.3 I believe that I will learn fast how to use self-driving car & P2V10easy-to-learn \\
\hline & $\begin{array}{c}2.3 \text { I believe that the ease of use of the self-driving car will encourage me to use } \\
\text { the car }\end{array}$ & $\begin{array}{l}\text { P2V11easy- } \\
\text { encourage }\end{array}$ \\
\hline \multirow{8}{*}{ 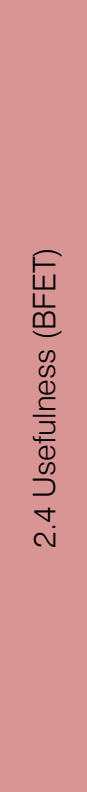 } & $2.4 \mathrm{I}$ believe self-driving car is efficient in reaching destination faster & $\begin{array}{l}\text { P2V12efficient- } \\
\text { destination }\end{array}$ \\
\hline & 2.4 I believe self-driving car provides comfort to me & P2V13 benefit-comfort \\
\hline & 2.4 I believe self-driving car is reliable as it depends on computers to work & P2V14 reliable \\
\hline & 2.4 I believe that self-driving car would be safe car & P2V15 benefit-safe \\
\hline & 2.4 I believe self-driving car would reduce traffic jam & P2V16 reduce-traffic \\
\hline & 2.4 Self-driving car will give me the chance to take benefit of the road time & P2V17road-time \\
\hline & 2.4 Self-driving car will reduce the pressure due to driving cars & $\begin{array}{l}\text { P2V18 reduce- } \\
\text { pleasure }\end{array}$ \\
\hline & $\begin{array}{c}2.4 \text { I believe that the benefits of the self-driving car will encourage me to own } \\
\text { the car }\end{array}$ & $\begin{array}{l}\text { P2V19 benefit- } \\
\text { encourage }\end{array}$ \\
\hline
\end{tabular}




\begin{tabular}{|c|c|}
\hline 3. Intention to turn into using self-driving (INT) \\
\hline I am willing to pay more for self-driving car & P3V1 willing-pay \\
\hline I believe self-driving car has a lot of benefits & P3V2 lot-benefits \\
\hline I would recommend trying self-driving car & P3V3 recommend-use \\
\hline I believe that self-driving car is easy to use & P3V4 ease-of-use \\
\hline I would buy self-driving car in future & P3V5 willing-buy \\
\hline Owning self-driving car is a great idea & P3V6 own-idea \\
\hline
\end{tabular}

Figure 12: Questionnaire used in the study

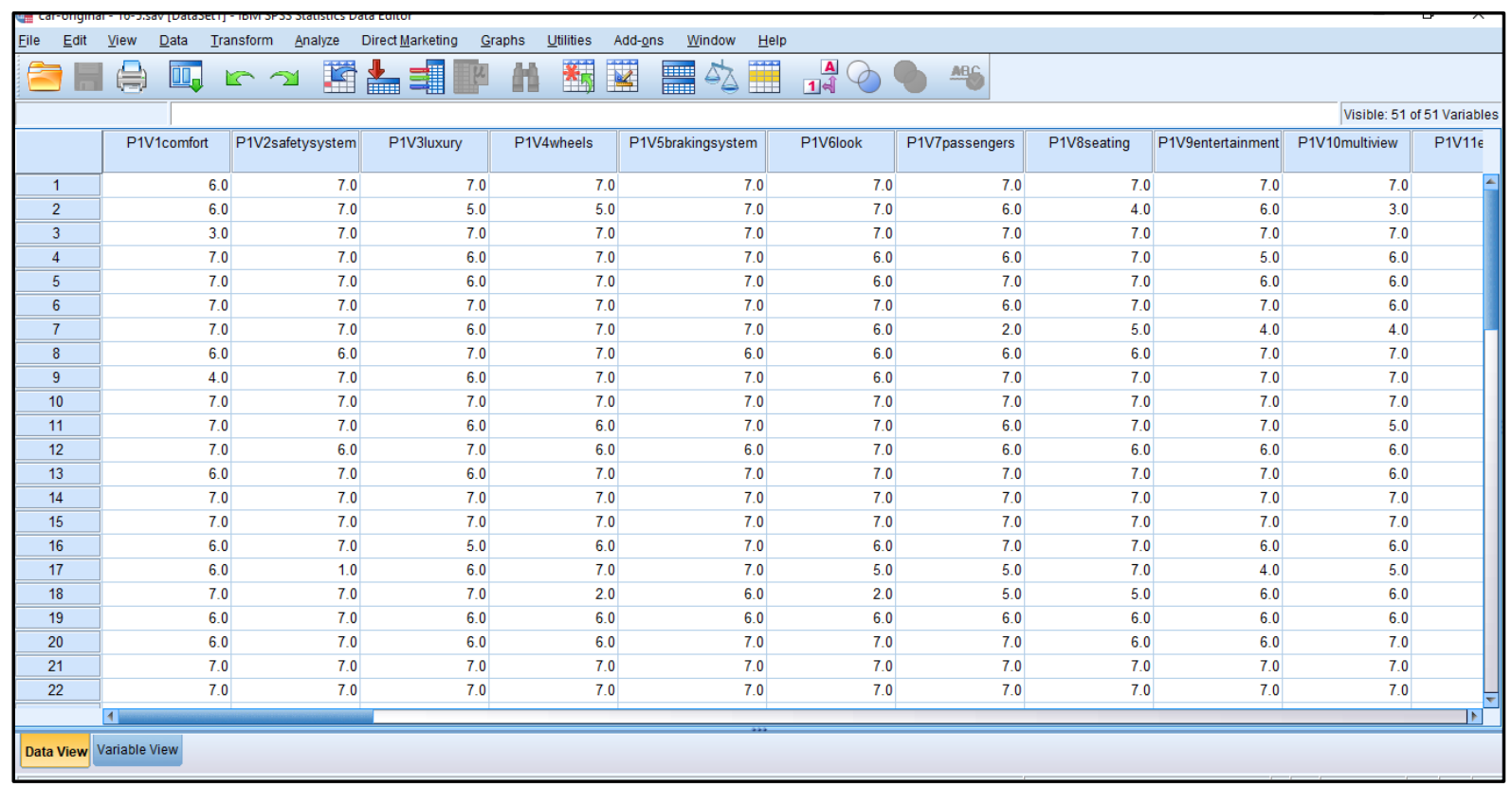

Figure 13: Data view in SPSS for the valid 39 survey entries

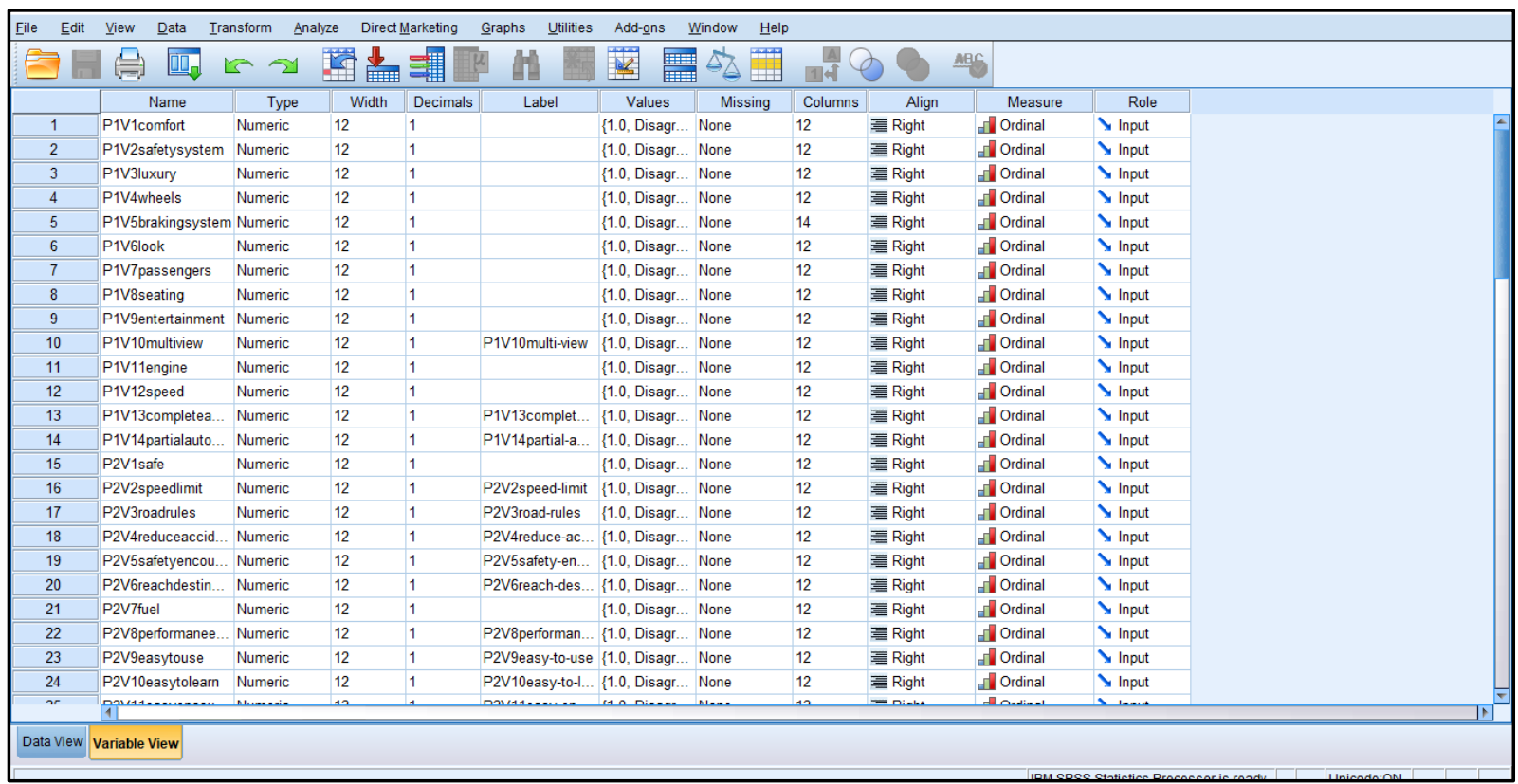

Figure 14: Variable view in SPSS for the survey used in the study 


\section{Appendix B}

a) Univariate Statistics for Demographics:

i. Descriptive Statistics: Demographics

The responses showed that percentage of Male respondent is $(51.3 \%)$ which slightly bigger than Female respondent's percentage that is (48.7\%) as seen in (Table 44 and figure15).

Table 44: Gender Frequency in the population

\begin{tabular}{|c|c|c|c|c|c|}
\hline \multicolumn{5}{|c|}{ Gender } \\
\hline \multirow{3}{*}{ Valid } & Frequency & Percent & Valid Percent & $\begin{array}{c}\text { Cumulative } \\
\text { Percent }\end{array}$ \\
\cline { 2 - 6 } & Male & 20 & 51.3 & 51.3 & 51.3 \\
\cline { 2 - 6 } & Female & 19 & 48.7 & 48.7 & 100.0 \\
\hline & Total & 39 & 100.0 & 100.0 & \\
\hline
\end{tabular}

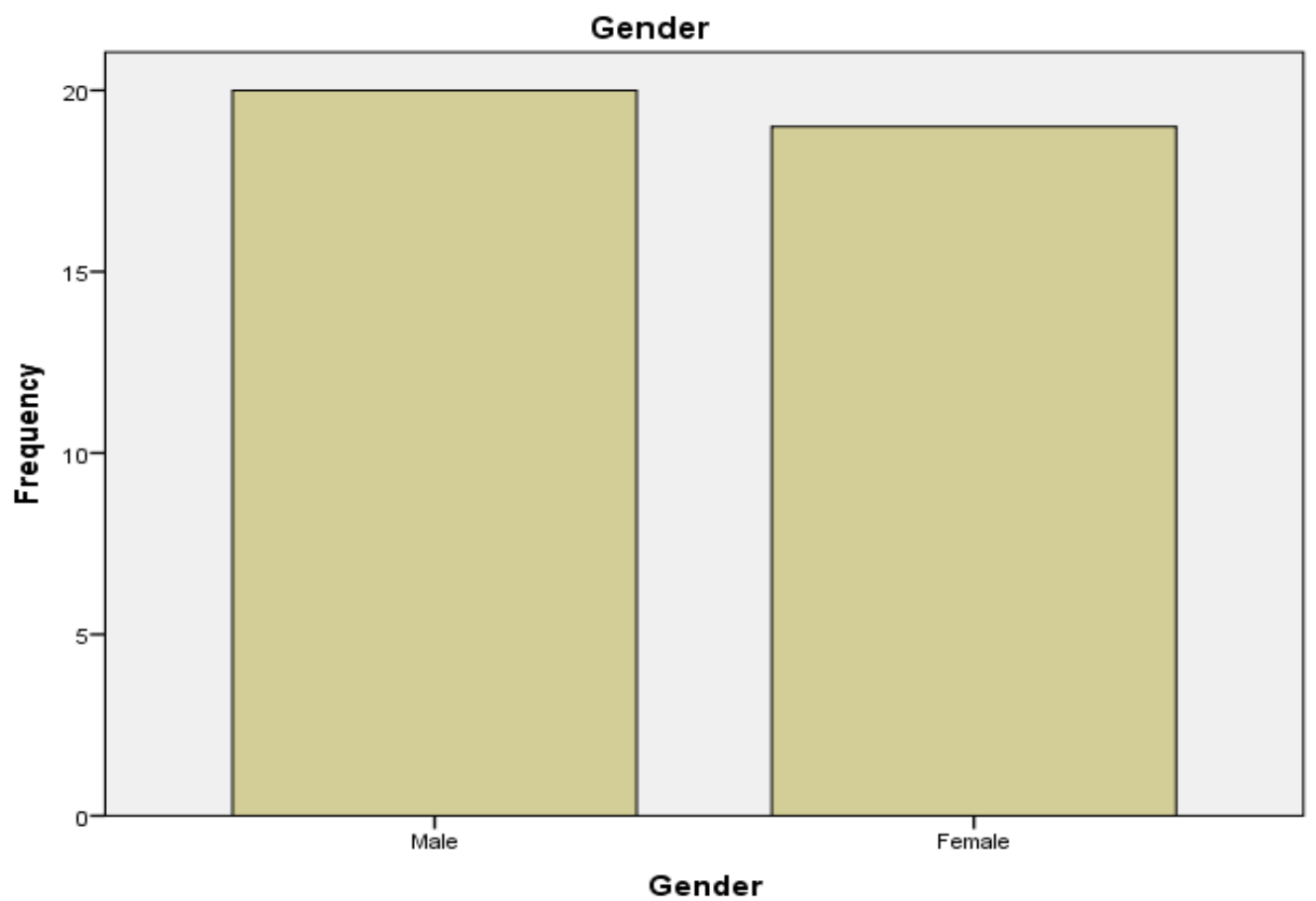

Figure 15: Presentation of Gender in the population

The responses showed that most of the respondents are between 30 and 49 years old, and only few respondents of age (50-59) participated in the survey of (7.7\%) as seen in table 45 and figure 16 below.

Table 45: Age Frequency in the population

\begin{tabular}{|c|c|c|c|c|c|}
\hline \multicolumn{2}{|c|}{ Age } \\
\hline \multirow{4}{*}{} & Frequency & Percent & Valid Percent & Cumulative Percent \\
\hline \multirow{4}{*}{ Valid } & Less than 30 & 10 & 25.6 & 25.6 & 25.6 \\
\cline { 2 - 6 } & $30-39$ & 13 & 33.3 & 33.3 & 59.0 \\
\cline { 2 - 6 } & $40-49$ & 13 & 33.3 & 33.3 & 92.3 \\
\cline { 2 - 6 } & $50-59$ & 3 & 7.7 & 7.7 & 100.0 \\
\cline { 2 - 6 } & Total & 39 & 100.0 & 100.0 & \\
\hline
\end{tabular}




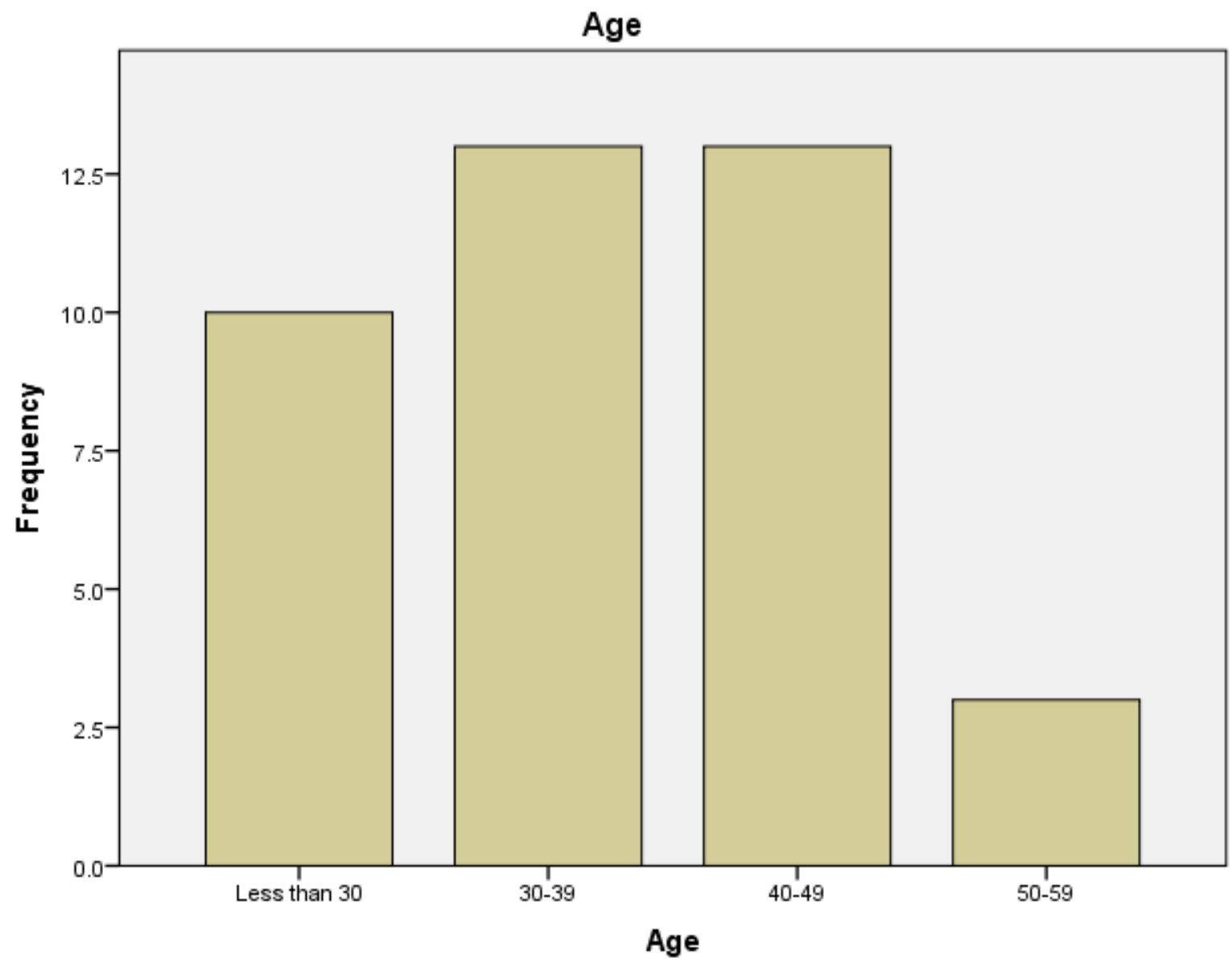

Figure 16: Presentation of Age in the population

The responses showed that people with bachelor's degree are the most respondents (64.1\%) as shown in figure 17 and table 46.

Table 46: Level of Education Frequency in the population

\begin{tabular}{|c|c|c|c|c|c|}
\hline \multicolumn{5}{|c|}{ Education } \\
\hline & Frequency & Percent & Valid Percent & Cumulative Percent \\
\hline \multirow{4}{*}{ Valid } & PHD & 2 & 5.1 & 5.1 & 5.1 \\
\cline { 2 - 6 } & Master & 9 & 23.1 & 23.1 & 28.2 \\
\cline { 2 - 6 } & Bachelor & 25 & 64.1 & 64.1 & 92.3 \\
\cline { 2 - 6 } & Diploma & 1 & 2.6 & 2.6 & 94.9 \\
\cline { 2 - 6 } & Highschool & 2 & 5.1 & 5.1 & 100.0 \\
\cline { 2 - 6 } & Total & 39 & 100.0 & 100.0 & \\
\hline
\end{tabular}




\section{Education}

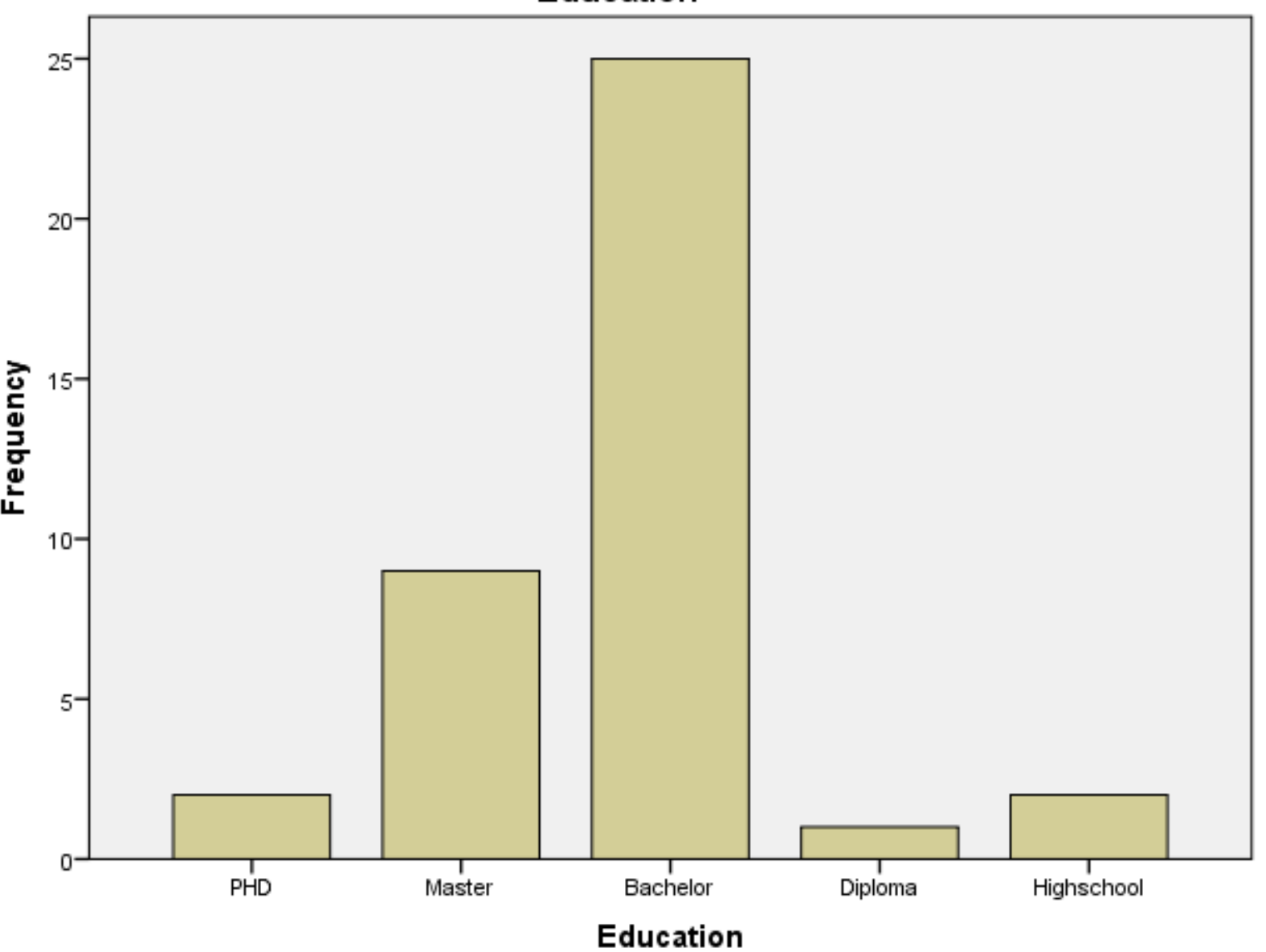

Figure 17: Presentation of Level of Education in the population

\section{ii. Descriptive Statistics: Driving Experience}

The responses showed that the majority (32.5\%) of respondents have driving experience of 15 to 20 years, while only (7.5\%) of respondents have driving experience of 5 to 9 years as seen in (Table 47 and figure 18) below.

Table 47: Driving Experience Frequency in the population

\begin{tabular}{|c|c|c|c|c|c|}
\hline \multicolumn{5}{|c|}{ Driving Experience } \\
\hline \multirow{4}{*}{} & Frequency & Percent & Valid Percent & Cumulative Percent \\
\hline \multirow{4}{*}{ Valid } & & & & \\
\cline { 2 - 6 } & Never & 4 & 10.3 & 10.3 & 10.3 \\
\cline { 2 - 6 } & Less than 5 years & 5 & 12.8 & 12.8 & 23.1 \\
\cline { 2 - 6 } & $5-9$ & 2 & 5.1 & 5.1 & 28.2 \\
\cline { 2 - 6 } & $10-14$ & 6 & 15.4 & 15.4 & 43.6 \\
\cline { 2 - 6 } & More than 20 years & 13 & 33.3 & 33.3 & 10.9 \\
\cline { 2 - 6 } & Total & 9 & 23.1 & 23.1 & \\
\hline
\end{tabular}




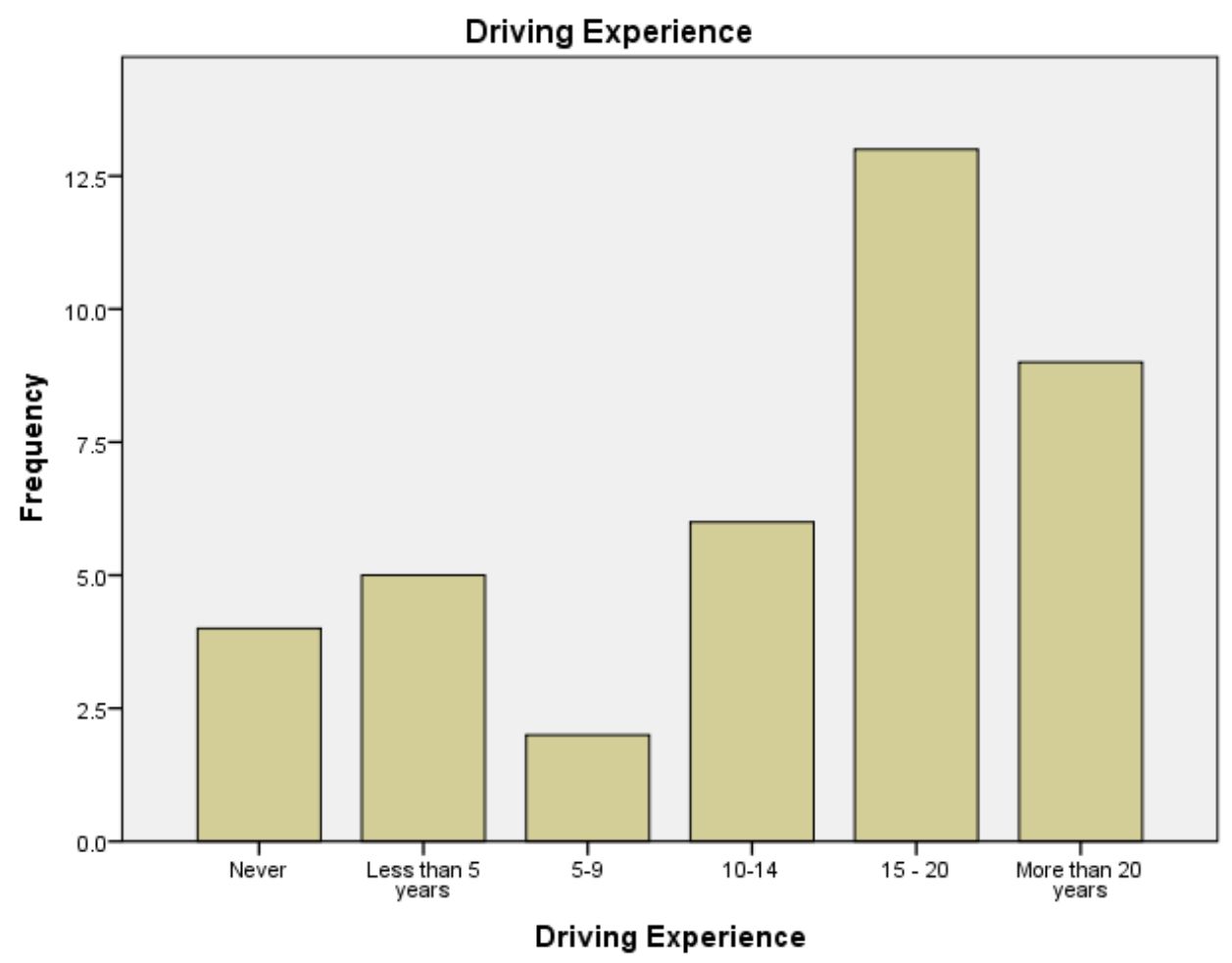

Figure 18: Presentation of driving experience in the population

iii. Descriptive Statistics: Nationality

The majority of respondent's nationality is UAE of (95\%) while only (5\%) of the respondents from Middle East as seen in (Table 48 and figure 19 below).

Table 48: Nationality Frequency in the population

\begin{tabular}{|c|c|c|c|c|c|}
\hline \multicolumn{5}{|c|}{ Nationality } \\
\hline \multirow{2}{*}{} & Frequency & Percent & Valid Percent & $\begin{array}{c}\text { Cumulative } \\
\text { Percent }\end{array}$ \\
\hline \multirow{3}{*}{ Valid } & UAE & 38 & 95.0 & 95.0 & 95.0 \\
\cline { 2 - 6 } & Middle East & 2 & 5.0 & 5.0 & 100.0 \\
\cline { 2 - 6 } & Total & 40 & 100.0 & 100.0 & \\
\hline
\end{tabular}

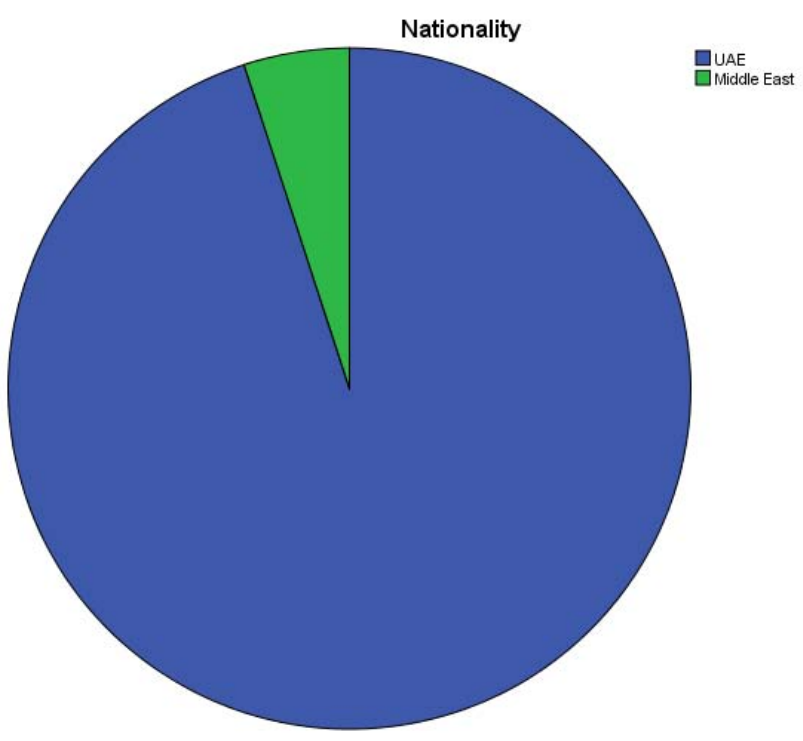

Figure 19: Presentation of Nationality of the population 
iv. Univariate Statistics for construct's variables:

a. Univariate Statistics for the attributes of the construct: specifications of self-driving car that user cares about:

Table 49: Descriptive Statistics: frequencies

\begin{tabular}{|c|c|c|c|c|c|}
\hline \multicolumn{2}{|c|}{} & Frequency & Percent & Valid Percent & $\begin{array}{c}\text { Cumulative } \\
\text { Percent }\end{array}$ \\
\hline \multirow{4}{*}{ Valid } & Slightly Disagree & 1 & 2.6 & 2.6 & 2.6 \\
\cline { 2 - 6 } & Neutral & 1 & 2.6 & 2.6 & 5.1 \\
\cline { 2 - 6 } & Agree & 15 & 38.5 & 38.5 & 43.6 \\
\cline { 2 - 6 } & Agree Strongly & 22 & 56.4 & 56.4 & 100.0 \\
\cline { 2 - 6 } & Total & 39 & 100.0 & 100.0 & \\
\hline
\end{tabular}

Table 50: Descriptive Statistics: frequencies

\begin{tabular}{|c|c|c|c|c|c|}
\hline \multicolumn{2}{|c|}{ P1V2safetysystem } \\
\hline \multirow{3}{*}{} & Frequency & Percent & Valid Percent & $\begin{array}{c}\text { Cumulative } \\
\text { Percent }\end{array}$ \\
\hline \multirow{4}{*}{ Valid } & Disagree Strongly & 1 & 2.6 & 2.6 & 2.6 \\
\cline { 2 - 6 } & Agree & 2 & 5.1 & 5.1 & 7.7 \\
\cline { 2 - 6 } & Agree Strongly & 36 & 92.3 & 92.3 & 100.0 \\
\cline { 2 - 6 } & Total & 39 & 100.0 & 100.0 & \\
\hline
\end{tabular}

Table 51: Descriptive Statistics: frequencies

\begin{tabular}{|c|c|c|c|c|c|}
\hline \multicolumn{6}{|c|}{ P1V3luxury } \\
\hline \multirow{3}{*}{} & Frequency & Percent & Valid Percent & $\begin{array}{c}\text { Cumulative } \\
\text { Percent }\end{array}$ \\
\hline \multirow{3}{*}{ Valid } & Slightly Agree & 3 & 7.7 & 7.7 & 7.7 \\
\cline { 2 - 6 } & Agree & 15 & 38.5 & 38.5 & 46.2 \\
\cline { 2 - 6 } & Agree Strongly & 21 & 53.8 & 53.8 & 100.0 \\
\cline { 2 - 6 } & Total & 39 & 100.0 & 100.0 & \\
\hline
\end{tabular}

Table 52: Descriptive Statistics: frequencies

\begin{tabular}{|c|c|c|c|c|c|}
\hline \multicolumn{2}{|c|}{} & \multirow{2}{*}{ Frequency } & Percent & Valid Percent & $\begin{array}{c}\text { Cumulative } \\
\text { Percent }\end{array}$ \\
\hline \multirow{4}{*}{ Valid } & Disagree & 1 & 2.6 & 2.6 & 2.6 \\
\cline { 2 - 6 } & Slightly Agree & 1 & 2.6 & 2.6 & 5.1 \\
\cline { 2 - 6 } & Agree & 8 & 20.5 & 20.5 & 25.6 \\
\cline { 2 - 6 } & Agree Strongly & 29 & 74.4 & 74.4 & 100.0 \\
\cline { 2 - 6 } & Total & 39 & 100.0 & 100.0 & \\
\hline
\end{tabular}

Table 53: Descriptive Statistics: frequencies

\begin{tabular}{|c|c|c|c|c|c|}
\hline \multicolumn{2}{|c|}{ P1V5brakingsystem } \\
\hline \multirow{2}{*}{} & Frequency & Percent & Valid Percent & $\begin{array}{c}\text { Cumulative } \\
\text { Percent }\end{array}$ \\
\hline \multirow{3}{*}{ Valid } & Agree & 6 & 15.4 & 15.4 & 15.4 \\
\cline { 2 - 6 } & Agree Strongly & 33 & 84.6 & 84.6 & 100.0 \\
\cline { 2 - 6 } & Total & 39 & 100.0 & 100.0 & \\
\hline
\end{tabular}

Table 54: Descriptive Statistics: frequencies

\begin{tabular}{|c|c|c|c|c|c|}
\hline \multicolumn{2}{|c|}{} & Frequency & Percent & Valid Percent & $\begin{array}{c}\text { Cumulative } \\
\text { Percent }\end{array}$ \\
\hline \multirow{4}{*}{ Valid } & Disagree & 1 & 2.6 & 2.6 & 2.6 \\
\cline { 2 - 6 } & Slightly Agree & 3 & 7.7 & 7.7 & 10.3 \\
\cline { 2 - 6 } & Agree & 11 & 28.2 & 28.2 & 38.5 \\
\cline { 2 - 6 } & Agree Strongly & 24 & 61.5 & 61.5 & 100.0 \\
\cline { 2 - 6 } & Total & 39 & 100.0 & 100.0 & \\
\hline
\end{tabular}


Table 55: Descriptive Statistics: frequencies

\begin{tabular}{|c|c|c|c|c|c|}
\hline \multicolumn{6}{|c|}{ P1V7passengers } \\
\hline \multirow{4}{*}{ Valid } & Frequency & Percent & Valid Percent & Cumulative Percent \\
\hline \multirow{4}{*}{} & Disagree & 1 & 2.6 & 2.6 & 2.6 \\
\cline { 2 - 6 } & Slightly Agree & 4 & 10.3 & 10.3 & 12.8 \\
\cline { 2 - 6 } & Agree & 15 & 38.5 & 38.5 & 51.3 \\
\cline { 2 - 6 } & Agree Strongly & 19 & 48.7 & 48.7 & 100.0 \\
\cline { 2 - 6 } & Total & 39 & 100.0 & 100.0 & \\
\hline
\end{tabular}

Table 56: Descriptive Statistics: frequencies

\begin{tabular}{|c|c|c|c|c|c|}
\hline \multicolumn{6}{|c|}{ P1V8seating } \\
\hline \multirow{4}{*}{ Valid } & Frequency & Percent & Valid Percent & Cumulative Percent \\
\cline { 2 - 6 } & Neutral & 1 & 2.6 & 2.6 & 2.6 \\
\cline { 2 - 6 } & Slightly Agree & 3 & 7.7 & 7.7 & 10.3 \\
\cline { 2 - 6 } & Agree & 8 & 20.5 & 20.5 & 30.8 \\
\cline { 2 - 6 } & Agree Strongly & 27 & 69.2 & 69.2 & 100.0 \\
\cline { 2 - 6 } & Total & 39 & 100.0 & 100.0 & \\
\hline
\end{tabular}

Table 57: Descriptive Statistics: frequencies:

\begin{tabular}{|c|c|c|c|c|c|}
\hline \multicolumn{7}{|c|}{ P1V9entertainment } \\
\hline \multirow{4}{*}{ Valid } & Frequency & Percent & Valid Percent & Cumulative Percent \\
\hline \multirow{4}{*}{} & Neutral & 3 & 7.7 & 7.7 & 7.7 \\
\cline { 2 - 6 } & Slightly Agree & 3 & 7.7 & 7.7 & 15.4 \\
\cline { 2 - 6 } & Agree & 13 & 33.3 & 33.3 & 48.7 \\
\cline { 2 - 6 } & Agree Strongly & 20 & 51.3 & 51.3 & 100.0 \\
\cline { 2 - 6 } & Total & 39 & 100.0 & 100.0 & \\
\hline
\end{tabular}

Table 58: Descriptive Statistics: frequencies

\begin{tabular}{|c|c|c|c|c|c|}
\hline \multicolumn{6}{|c|}{ P1V10multi-view } \\
\hline \multirow{4}{*}{ Valid } & Frequency & Percent & Valid Percent & Cumulative Percent \\
\cline { 2 - 7 } & Slightly Disagree & 1 & 2.6 & 2.6 & 2.6 \\
\cline { 2 - 7 } & Neutral & 1 & 2.6 & 2.6 & 5.1 \\
\cline { 2 - 7 } & Slightly Agree & 5 & 12.8 & 12.8 & 17.9 \\
\cline { 2 - 7 } & Agree & 14 & 35.9 & 35.9 & 53.8 \\
\cline { 2 - 7 } & Agree Strongly & 18 & 46.2 & 46.2 & 100.0 \\
\cline { 2 - 7 } & Total & 39 & 100.0 & 100.0 & \\
\hline \multirow{5}{*}{ Valid } & Frequency & Percent & Valid Percent & Cumulative Percent \\
\cline { 2 - 7 } & Slightly Disagree & 1 & 2.6 & 2.6 & 2.6 \\
\cline { 2 - 7 } & Slightly Agree & 4 & 10.3 & 10.3 & 35.9 \\
\cline { 2 - 7 } & Agree & 9 & 23.1 & 23.1 & 100.0 \\
\cline { 2 - 7 } & Agree Strongly & 25 & 64.1 & 64.1 & 100.0 \\
\hline
\end{tabular}

Table 59: Descriptive Statistics: frequencies

\begin{tabular}{|c|c|c|c|c|c|}
\hline \multicolumn{2}{|c|}{} & \multirow{2}{*}{ Prequency } & Percent & Valid Percent & $\begin{array}{c}\text { Cumulative } \\
\text { Percent }\end{array}$ \\
\hline \multirow{4}{*}{ Valid } & Slightly Disagree & 1 & 2.6 & 2.6 & 2.6 \\
\cline { 2 - 6 } & Slightly Agree & 5 & 12.8 & 12.8 & 15.4 \\
\cline { 2 - 6 } & Agree & 15 & 38.5 & 38.5 & 53.8 \\
\cline { 2 - 6 } & Agree Strongly & 18 & 46.2 & 46.2 & 100.0 \\
\cline { 2 - 6 } & Total & 39 & 100.0 & 100.0 & \\
\hline
\end{tabular}


Table 60: Descriptive Statistics: frequencies

\begin{tabular}{|c|c|c|c|c|c|}
\hline \multicolumn{7}{|c|}{ P1V13complete-autonomous } \\
\hline \multirow{4}{*}{} & Frequency & Percent & Valid Percent & $\begin{array}{c}\text { Cumulative } \\
\text { Percent }\end{array}$ \\
\hline \multirow{4}{*}{ Valid } & Disagree & 2 & 5.1 & 5.1 & 5.1 \\
\cline { 2 - 6 } & Sightly Disagree & 2 & 5.1 & 5.1 & 10.3 \\
\cline { 2 - 6 } & Neutral & 4 & 10.3 & 10.3 & 20.5 \\
\cline { 2 - 6 } & Slightly Agree & 10 & 25.6 & 25.6 & 46.2 \\
\cline { 2 - 6 } & Agree & 11 & 28.2 & 28.2 & 74.4 \\
\cline { 2 - 6 } & Agree Strongly & 10 & 25.6 & 25.6 & 100.0 \\
\cline { 2 - 6 } & Total & 39 & 100.0 & 100.0 & \\
\hline
\end{tabular}

Table 61: Descriptive Statistics: frequencies

\begin{tabular}{|c|c|c|c|c|c|}
\hline \multicolumn{6}{|c|}{ P1V14partial-autonomous } \\
\hline & & Frequency & Percent & Valid Percent & Cumulative Percent \\
\hline \multirow{5}{*}{ Valid } & Neutral & 1 & 2.6 & 2.6 & 2.6 \\
\hline & Slightly Agree & 6 & 15.4 & 15.4 & 17.9 \\
\hline & Agree & 15 & 38.5 & 38.5 & 56.4 \\
\hline & Agree Strongly & 17 & 43.6 & 43.6 & 100.0 \\
\hline & Total & 39 & 100.0 & 100.0 & \\
\hline
\end{tabular}

b. Univariate Statistics for the attributes of the construct: features of self-driving car that user interested in:

Table 62: Descriptive Statistics: frequencies

\begin{tabular}{|c|c|c|c|c|c|}
\hline \multicolumn{9}{|c|}{} & \multicolumn{2}{c|}{ P2V1safe } \\
\hline \multirow{4}{*}{} & Frequency & Percent & Valid Percent & $\begin{array}{c}\text { Cumulative } \\
\text { Percent }\end{array}$ \\
\hline \multirow{4}{*}{ Valid } & Disagree Strongly & 1 & 2.6 & 2.6 & 2.6 \\
\cline { 2 - 6 } & Slightly Disagree & 1 & 2.6 & 2.6 & 5.1 \\
\cline { 2 - 6 } & Neutral & 4 & 10.3 & 10.3 & 15.4 \\
\cline { 2 - 6 } & Slightly Agree & 11 & 28.2 & 28.2 & 43.6 \\
\cline { 2 - 6 } & Agree & 14 & 35.9 & 35.9 & 79.5 \\
\cline { 2 - 6 } & Agree Strongly & 8 & 20.5 & 20.5 & 100.0 \\
\cline { 2 - 6 } & Total & 39 & 100.0 & 100.0 & \\
\hline
\end{tabular}

Table 63: Descriptive Statistics: frequencies

\begin{tabular}{|c|c|c|c|c|c|}
\hline \multicolumn{6}{|c|}{ P2V2speed-limit } \\
\hline \multicolumn{1}{|c|}{} & Frequency & Percent & Valid Percent & $\begin{array}{c}\text { Cumulative } \\
\text { Percent }\end{array}$ \\
\hline \multirow{4}{*}{ Valid } & Disagree & 1 & 2.6 & 2.6 & 2.6 \\
\cline { 2 - 6 } & Slightly Disagree & 1 & 2.6 & 2.6 & 5.1 \\
\cline { 2 - 6 } & Neutral & 3 & 7.7 & 7.7 & 12.8 \\
\cline { 2 - 6 } & Slightly Agree & 9 & 23.1 & 23.1 & 35.9 \\
\cline { 2 - 6 } & Agree & 17 & 43.6 & 43.6 & 79.5 \\
\cline { 2 - 6 } & Agree Strongly & 8 & 20.5 & 20.5 & 100.0 \\
\cline { 2 - 6 } & Total & 39 & 100.0 & 100.0 & \\
\hline
\end{tabular}

Table 64: Descriptive Statistics: frequencies

\begin{tabular}{|c|c|c|c|c|c|}
\hline \multicolumn{5}{|c|}{ P2V3road-rules } \\
\hline \multicolumn{1}{|c|}{} & Frequency & Percent & Valid Percent & $\begin{array}{c}\text { Cumulative } \\
\text { Percent }\end{array}$ \\
\hline \multirow{4}{*}{ Valid } & Disagree & 1 & 2.6 & 2.6 & 2.6 \\
\cline { 2 - 6 } & Slightly Disagree & 2 & 5.1 & 5.1 & 7.7 \\
\cline { 2 - 6 } & Neutral & 5 & 12.8 & 12.8 & 20.5 \\
\cline { 2 - 6 } & Slightly Agree & 8 & 20.5 & 20.5 & 41.0 \\
\cline { 2 - 6 } & Agree & 12 & 30.8 & 30.8 & 71.8 \\
\cline { 2 - 6 } & Agree Strongly & 11 & 28.2 & 28.2 & 100.0 \\
\cline { 2 - 6 } & Total & 39 & 100.0 & 100.0 & \\
\hline
\end{tabular}


Table 65: Descriptive Statistics: frequencies

\begin{tabular}{|c|c|c|c|c|c|}
\hline \multicolumn{7}{|c|}{ P2V4reduce-accidents } \\
\hline \multirow{4}{*}{} & Frequency & Percent & Valid Percent & $\begin{array}{c}\text { Cumulative } \\
\text { Percent }\end{array}$ \\
\hline \multirow{4}{*}{ Valid } & Disagree Strongly & 1 & 2.6 & 2.6 & 2.6 \\
\cline { 2 - 6 } & Slightly Disagree & 4 & 10.3 & 10.3 & 12.8 \\
\cline { 2 - 6 } & Neutral & 7 & 17.9 & 17.9 & 30.8 \\
\cline { 2 - 6 } & Slightly Agree & 7 & 17.9 & 17.9 & 48.7 \\
\cline { 2 - 6 } & Agree & 13 & 33.3 & 33.3 & 82.1 \\
\cline { 2 - 6 } & Agree Strongly & 7 & 17.9 & 17.9 & 100.0 \\
\cline { 2 - 6 } & Total & 39 & 100.0 & 100.0 & \\
\hline
\end{tabular}

Table 66: Descriptive Statistics: frequencies

\begin{tabular}{|c|c|c|c|c|c|}
\hline \multicolumn{7}{|c|}{ P2V5safety-encourage } \\
\hline \multirow{4}{*}{} & Frequency & Percent & Valid Percent & $\begin{array}{c}\text { Cumulative } \\
\text { Percent }\end{array}$ \\
\hline \multirow{4}{*}{ Valid } & Disagree & 1 & 2.6 & 2.6 & 2.6 \\
\cline { 2 - 6 } & Neutral & 4 & 10.3 & 10.3 & 12.8 \\
\cline { 2 - 6 } & Slightly Agree & 9 & 23.1 & 23.1 & 35.9 \\
\cline { 2 - 6 } & Agree & 15 & 38.5 & 38.5 & 74.4 \\
\cline { 2 - 6 } & Agree Strongly & 10 & 25.6 & 25.6 & 100.0 \\
\cline { 2 - 6 } & Total & 39 & 100.0 & 100.0 & \\
\hline
\end{tabular}

Table 67: Descriptive Statistics: frequencies

\begin{tabular}{|c|c|c|c|c|c|}
\hline \multicolumn{5}{|c|}{ P2V6reach-destination } \\
\hline \multicolumn{1}{|c|}{} & Frequency & Percent & Valid Percent & $\begin{array}{c}\text { Cumulative } \\
\text { Percent }\end{array}$ \\
\hline \multirow{4}{*}{ Valid } & Disagree Strongly & 1 & 2.6 & 2.6 & 2.6 \\
\cline { 2 - 6 } & Disagree & 2 & 5.1 & 5.1 & 7.7 \\
\cline { 2 - 6 } & Slightly Disagree & 3 & 7.7 & 7.7 & 15.4 \\
\cline { 2 - 6 } & Neutral & 4 & 10.3 & 10.3 & 25.6 \\
\cline { 2 - 6 } & Slightly Agree & 8 & 20.5 & 20.5 & 46.2 \\
\cline { 2 - 6 } & Agree & 13 & 33.3 & 33.3 & 79.5 \\
\cline { 2 - 6 } & Agree Strongly & 8 & 20.5 & 20.5 & 100.0 \\
\cline { 2 - 6 } & Total & 39 & 100.0 & 100.0 & \\
\hline
\end{tabular}

Table 68: Descriptive Statistics: frequencies

\begin{tabular}{|c|c|c|c|c|c|}
\hline \multicolumn{6}{|c|}{ P2V7fuel } \\
\hline \multirow{2}{*}{} & Frequency & Percent & Valid Percent & $\begin{array}{c}\text { Cumulative } \\
\text { Percent }\end{array}$ \\
\hline \multirow{4}{*}{ Valid } & Disagree & 1 & 2.6 & 2.6 & 2.6 \\
\cline { 2 - 6 } & Slightly Disagree & 4 & 10.3 & 10.3 & 12.8 \\
\cline { 2 - 6 } & Neutral & 2 & 5.1 & 5.1 & 17.9 \\
\cline { 2 - 6 } & Slightly Agree & 12 & 30.8 & 30.8 & 48.7 \\
\cline { 2 - 6 } & Agree & 10 & 25.6 & 25.6 & 74.4 \\
\cline { 2 - 6 } & Agree Strongly & 10 & 25.6 & 25.6 & 100.0 \\
\cline { 2 - 6 } & Total & 39 & 100.0 & 100.0 & \\
\hline
\end{tabular}

Table 69: Descriptive Statistics: frequencies

\begin{tabular}{|c|c|c|c|c|c|}
\hline \multicolumn{7}{|c|}{ P2V8performane-encourage } \\
\hline \multicolumn{1}{|c|}{} & Frequency & Percent & Valid Percent & $\begin{array}{c}\text { Cumulative } \\
\text { Percent }\end{array}$ \\
\hline \multirow{4}{*}{ Valid } & Disagree & 1 & 2.6 & 2.6 & 2.6 \\
\cline { 2 - 6 } & Slightly Disagree & 1 & 2.6 & 2.6 & 5.1 \\
\cline { 2 - 6 } & Neutral & 3 & 7.7 & 7.7 & 12.8 \\
\cline { 2 - 6 } & Slightly Agree & 11 & 28.2 & 28.2 & 41.0 \\
\cline { 2 - 6 } & Agree & 14 & 35.9 & 35.9 & 76.9 \\
\cline { 2 - 6 } & Agree Strongly & 9 & 23.1 & 23.1 & 100.0 \\
\cline { 2 - 6 } & Total & 39 & 100.0 & 100.0 & \\
\hline
\end{tabular}


Table 70: Descriptive Statistics: frequencies

\begin{tabular}{|c|c|c|c|c|c|}
\hline \multicolumn{6}{|c|}{ P2V9easy-to-use } \\
\hline \multirow{4}{*}{} & Frequency & Percent & Valid Percent & $\begin{array}{c}\text { Cumulative } \\
\text { Percent }\end{array}$ \\
\hline \multirow{4}{*}{ Valid } & Disagree & 3 & 7.7 & 7.7 & 7.7 \\
\cline { 2 - 6 } & Neutral & 1 & 2.6 & 2.6 & 10.3 \\
\cline { 2 - 6 } & Slightly Agree & 12 & 30.8 & 30.8 & 41.0 \\
\cline { 2 - 6 } & Agree & 14 & 35.9 & 35.9 & 76.9 \\
\cline { 2 - 6 } & Agree Strongly & 9 & 23.1 & 23.1 & 100.0 \\
\cline { 2 - 6 } & Total & 39 & 100.0 & 100.0 & \\
\hline
\end{tabular}

Table 71: Descriptive Statistics: frequencies

\begin{tabular}{|c|c|c|c|c|c|}
\hline \multicolumn{2}{|c|}{ P2V10easy-to-learn } \\
\hline \multirow{2}{*}{} & Frequency & Percent & Valid Percent & $\begin{array}{c}\text { Cumulative } \\
\text { Percent }\end{array}$ \\
\hline \multirow{4}{*}{ Valid } & Disagree & 1 & 2.6 & 2.6 & 2.6 \\
\cline { 2 - 6 } & Slightly Disagree & 1 & 2.6 & 2.6 & 5.1 \\
\cline { 2 - 6 } & Slightly Agree & 9 & 23.1 & 23.1 & 28.2 \\
\cline { 2 - 6 } & Agree & 16 & 41.0 & 41.0 & 69.2 \\
\cline { 2 - 6 } & Agree Strongly & 12 & 30.8 & 30.8 & 100.0 \\
\cline { 2 - 6 } & Total & 39 & 100.0 & 100.0 & \\
\hline
\end{tabular}

Table 72: Descriptive Statistics: frequencies

\begin{tabular}{|c|c|c|c|c|c|}
\hline \multicolumn{5}{|c|}{ P2V11easy-encourage } \\
\hline \multicolumn{1}{|c|}{} & Frequency & Percent & Valid Percent & $\begin{array}{c}\text { Cumulative } \\
\text { Percent }\end{array}$ \\
\hline \multirow{4}{*}{ Valid } & Neutral & 3 & 7.7 & 7.7 & 7.7 \\
\cline { 2 - 6 } & Slightly Agree & 9 & 23.1 & 23.1 & 30.8 \\
\cline { 2 - 6 } & Agree & 19 & 48.7 & 48.7 & 79.5 \\
\cline { 2 - 6 } & Agree Strongly & 8 & 20.5 & 20.5 & 100.0 \\
\cline { 2 - 6 } & Total & 39 & 100.0 & 100.0 & \\
\hline
\end{tabular}

Table 73: Descriptive Statistics: frequencies

\begin{tabular}{|c|c|c|c|c|c|}
\hline \multicolumn{6}{|c|}{ P2V12efficient-destination } \\
\hline & & Frequency & Percent & Valid Percent & $\begin{array}{c}\text { Cumulative } \\
\text { Percent }\end{array}$ \\
\hline \multirow{7}{*}{ Valid } & Disagree Strongly & 1 & 2.6 & 2.6 & 2.6 \\
\hline & Slightly Disagree & 1 & 2.6 & 2.6 & 5.1 \\
\hline & Neutral & 5 & 12.8 & 12.8 & 17.9 \\
\hline & Slightly Agree & 10 & 25.6 & 25.6 & 43.6 \\
\hline & Agree & 13 & 33.3 & 33.3 & 76.9 \\
\hline & Agree Strongly & 9 & 23.1 & 23.1 & 100.0 \\
\hline & Total & 39 & 100.0 & 100.0 & \\
\hline
\end{tabular}

Table 74: Descriptive Statistics: frequencies

\begin{tabular}{|c|c|c|c|c|c|}
\hline \multicolumn{5}{|c|}{ P2V13 benefit-comfort } \\
\hline & Frequency & Percent & Valid Percent & $\begin{array}{c}\text { Cumulative } \\
\text { Percent }\end{array}$ \\
\hline \multirow{4}{*}{ Valid } & Slightly Disagree & 1 & 2.6 & 2.6 & 2.6 \\
\cline { 2 - 6 } & Neutral & 2 & 5.1 & 5.1 & 7.7 \\
\cline { 2 - 6 } & Slightly Agree & 8 & 20.5 & 20.5 & 28.2 \\
\cline { 2 - 6 } & Agree & 14 & 35.9 & 35.9 & 64.1 \\
\cline { 2 - 6 } & Agree Strongly & 14 & 35.9 & 35.9 & 100.0 \\
\cline { 2 - 6 } & Total & 39 & 100.0 & 100.0 & \\
\hline
\end{tabular}


Table 75: Descriptive Statistics: frequencies

\begin{tabular}{|c|c|c|c|c|c|}
\hline \multicolumn{7}{|c|}{ P2V14 reliable } \\
\hline \multirow{4}{*}{} & Frequency & Percent & Valid Percent & $\begin{array}{c}\text { Cumulative } \\
\text { Percent }\end{array}$ \\
\hline \multirow{4}{*}{ Valid } & Disagree & 3 & 7.7 & 7.7 & 7.7 \\
\cline { 2 - 6 } & Slightly Disagree & 2 & 5.1 & 5.1 & 12.8 \\
\cline { 2 - 6 } & Neutral & 5 & 12.8 & 12.8 & 25.6 \\
\cline { 2 - 6 } & Slightly Agree & 11 & 28.2 & 28.2 & 53.8 \\
\cline { 2 - 6 } & Agree & 11 & 28.2 & 28.2 & 82.1 \\
\cline { 2 - 6 } & Agree Strongly & 7 & 17.9 & 17.9 & 100.0 \\
\cline { 2 - 6 } & Total & 39 & 100.0 & 100.0 & \\
\hline
\end{tabular}

Table 76: Descriptive Statistics: frequencies

\begin{tabular}{|c|c|c|c|c|c|}
\hline \multicolumn{5}{|c|}{ P2V15 benefit-safe } \\
\hline \multicolumn{1}{|c|}{} & Frequency & Percent & Valid Percent & $\begin{array}{c}\text { Cumulative } \\
\text { Percent }\end{array}$ \\
\hline \multirow{4}{*}{ Valid } & Disagree Strongly & 1 & 2.6 & 2.6 & 2.6 \\
\cline { 2 - 6 } & Disagree & 1 & 2.6 & 2.6 & 5.1 \\
\cline { 2 - 6 } & Neutral & 6 & 15.4 & 15.4 & 20.5 \\
\cline { 2 - 6 } & Slightly Agree & 11 & 28.2 & 28.2 & 48.7 \\
\cline { 2 - 6 } & Agree & 14 & 35.9 & 35.9 & 84.6 \\
\cline { 2 - 6 } & Agree Strongly & 6 & 15.4 & 15.4 & 100.0 \\
\cline { 2 - 6 } & Total & 39 & 100.0 & 100.0 & \\
\hline
\end{tabular}

Table 77: Descriptive Statistics: frequencies

\begin{tabular}{|c|c|c|c|c|c|}
\hline \multicolumn{7}{|c|}{ P2V16 reduce-traffic } \\
\hline \multirow{2}{*}{} & Frequency & Percent & Valid Percent & $\begin{array}{c}\text { Cumulative } \\
\text { Percent }\end{array}$ \\
\hline \multirow{4}{*}{ Valid } & Slightly Disagree & 3 & 7.7 & 7.7 & 7.7 \\
\cline { 2 - 6 } & Neutral & 7 & 17.9 & 17.9 & 25.6 \\
\cline { 2 - 6 } & Slightly Agree & 12 & 30.8 & 30.8 & 56.4 \\
\cline { 2 - 6 } & Agree & 8 & 20.5 & 20.5 & 76.9 \\
\cline { 2 - 6 } & Agree Strongly & 9 & 23.1 & 23.1 & 100.0 \\
\cline { 2 - 6 } & Total & 39 & 100.0 & 100.0 & \\
\hline
\end{tabular}

Table 78: Descriptive Statistics: frequencies

\begin{tabular}{|c|c|c|c|c|c|}
\hline \multicolumn{5}{|c|}{ P2V17road-time } \\
\hline \multirow{4}{*}{} & Frequency & Percent & Valid Percent & $\begin{array}{c}\text { Cumulative } \\
\text { Percent }\end{array}$ \\
\hline \multirow{4}{*}{ Valid } & Slightly Disagree & 2 & 5.1 & 5.1 & 5.1 \\
\cline { 2 - 6 } & Neutral & 2 & 5.1 & 5.1 & 10.3 \\
\cline { 2 - 6 } & Slightly Agree & 7 & 17.9 & 17.9 & 28.2 \\
\cline { 2 - 6 } & Agree & 11 & 28.2 & 28.2 & 56.4 \\
\cline { 2 - 6 } & Agree Strongly & 17 & 43.6 & 43.6 & 100.0 \\
\cline { 2 - 6 } & Total & 39 & 100.0 & 100.0 & \\
\hline
\end{tabular}

Table 79: Descriptive Statistics: frequencies

\begin{tabular}{|c|c|c|c|c|c|}
\hline \multicolumn{7}{|c|}{ P2V18 reduce-pressure } \\
\hline \multicolumn{1}{|c|}{} & Frequency & Percent & Valid Percent & $\begin{array}{c}\text { Cumulative } \\
\text { Percent }\end{array}$ \\
\hline \multirow{4}{*}{ Valid } & Disagree & 1 & 2.6 & 2.6 & 2.6 \\
\cline { 2 - 6 } & Neutral & 4 & 10.3 & 10.3 & 12.8 \\
\cline { 2 - 6 } & Slightly Agree & 5 & 12.8 & 12.8 & 25.6 \\
\cline { 2 - 6 } & Agree & 11 & 28.2 & 28.2 & 53.8 \\
\cline { 2 - 6 } & Agree Strongly & 18 & 46.2 & 46.2 & 100.0 \\
\cline { 2 - 6 } & Total & 39 & 100.0 & 100.0 & \\
\hline
\end{tabular}


Table 80: Descriptive Statistics: frequencies

\begin{tabular}{|c|c|c|c|c|c|}
\hline \multicolumn{2}{|c|}{ P2V19 benefit-encourage } \\
\hline \multicolumn{1}{|c|}{} & Frequency & Percent & Valid Percent & $\begin{array}{c}\text { Cumulative } \\
\text { Percent }\end{array}$ \\
\hline \multirow{4}{*}{ Valid } & Disagree Strongly & 1 & 2.6 & 2.6 & 2.6 \\
\cline { 2 - 6 } & Disagree & 1 & 2.6 & 2.6 & 5.1 \\
\cline { 2 - 6 } & Slightly Disagree & 2 & 5.1 & 5.1 & 10.3 \\
\cline { 2 - 6 } & Neutral & 1 & 2.6 & 2.6 & 12.8 \\
\cline { 2 - 6 } & Slightly Agree & 6 & 15.4 & 15.4 & 28.2 \\
\cline { 2 - 6 } & Agree & 13 & 33.3 & 33.3 & 61.5 \\
\cline { 2 - 6 } & Agree Strongly & 15 & 38.5 & 38.5 & 100.0 \\
\cline { 2 - 6 } & Total & 39 & 100.0 & 100.0 & \\
\hline
\end{tabular}

c. Univariate Statistics for attributes of intention to turn into using self-driving car construct:

Table 81: Descriptive Statistics: frequencies

\begin{tabular}{|c|c|c|c|c|c|}
\hline \multicolumn{5}{|c|}{ P3V1 willing-pay } \\
\hline \multirow{4}{*}{} & Frequency & Percent & Valid Percent & $\begin{array}{c}\text { Cumulative } \\
\text { Percent }\end{array}$ \\
\hline \multirow{4}{*}{ Valid } & Disagree Strongly & 1 & 2.6 & 2.6 & 2.6 \\
\cline { 2 - 6 } & Disagree & 1 & 2.6 & 2.6 & 5.1 \\
\cline { 2 - 6 } & Slightly Disagree & 4 & 10.3 & 10.3 & 15.4 \\
\cline { 2 - 6 } & Neutral & 5 & 12.8 & 12.8 & 28.2 \\
\cline { 2 - 6 } & Slightly Agree & 10 & 25.6 & 25.6 & 53.8 \\
\cline { 2 - 6 } & Agree & 12 & 30.8 & 30.8 & 84.6 \\
\cline { 2 - 6 } & Agree Strongly & 6 & 15.4 & 15.4 & 100.0 \\
\cline { 2 - 6 } & Total & 39 & 100.0 & 100.0 & \\
\hline
\end{tabular}

Table 82: Descriptive Statistics: frequencies

\begin{tabular}{|c|c|c|c|c|c|}
\hline \multicolumn{2}{|c|}{} & P3V2 lot-benefits & \\
\hline \multirow{2}{*}{} & Frequency & Percent & Valid Percent & $\begin{array}{c}\text { Cumulative } \\
\text { Percent }\end{array}$ \\
\hline \multirow{4}{*}{ Valid } & Neutral & 4 & 10.3 & 10.3 & 10.3 \\
\cline { 2 - 6 } & Slightly Agree & 8 & 20.5 & 20.5 & 30.8 \\
\cline { 2 - 6 } & Agree & 16 & 41.0 & 41.0 & 71.8 \\
\cline { 2 - 6 } & Agree Strongly & 11 & 28.2 & 28.2 & 100.0 \\
\cline { 2 - 6 } & Total & 39 & 100.0 & 100.0 & \\
\hline
\end{tabular}

Table 83: Descriptive Statistics: frequencies

\begin{tabular}{|c|c|c|c|c|c|}
\hline \multicolumn{5}{|c|}{ P3V3 recommend-use } \\
\hline \multicolumn{1}{|c|}{} & Frequency & Percent & Valid Percent & $\begin{array}{c}\text { Cumulative } \\
\text { Percent }\end{array}$ \\
\hline \multirow{4}{*}{ Valid } & Disagree Strongly & 1 & 2.6 & 2.6 & 2.6 \\
\cline { 2 - 6 } & Neutral & 8 & 20.5 & 20.5 & 23.1 \\
\cline { 2 - 6 } & Slightly Agree & 6 & 15.4 & 15.4 & 38.5 \\
\cline { 2 - 6 } & Agree & 9 & 23.1 & 23.1 & 61.5 \\
\cline { 2 - 6 } & Agree Strongly & 15 & 38.5 & 38.5 & 100.0 \\
\cline { 2 - 6 } & Total & 39 & 100.0 & 100.0 & \\
\hline
\end{tabular}

Table 84: Descriptive Statistics: frequencies

\begin{tabular}{|c|c|c|c|c|c|}
\hline \multicolumn{7}{|c|}{ P3V4 ease-of-use } \\
\hline \multicolumn{1}{|c|}{} & Frequency & Percent & Valid Percent & Cumulative Percent \\
\hline \multirow{4}{*}{ Valid } & Disagree & 1 & 2.6 & 2.6 & 2.6 \\
\cline { 2 - 6 } & Slightly Disagree & 1 & 2.6 & 2.6 & 5.1 \\
\cline { 2 - 6 } & Neutral & 4 & 10.3 & 10.3 & 15.4 \\
\cline { 2 - 6 } & Slightly Agree & 9 & 23.1 & 23.1 & 38.5 \\
\cline { 2 - 6 } & Agree & 12 & 30.8 & 30.8 & 69.2 \\
\cline { 2 - 6 } & Agree Strongly & 12 & 30.8 & 30.8 & 100.0 \\
\cline { 2 - 6 } & Total & 39 & 100.0 & 100.0 & \\
\hline
\end{tabular}


Table 85: Descriptive Statistics: frequencies

\begin{tabular}{|c|c|c|c|c|c|}
\hline \multicolumn{6}{|c|}{ P3V5 willing-buy } \\
\hline \multirow{4}{*}{} & Frequency & Percent & Valid Percent & $\begin{array}{c}\text { Cumulative } \\
\text { Percent }\end{array}$ \\
\hline \multirow{4}{*}{ Valid } & Disagree & 3 & 7.7 & 7.7 & 7.7 \\
\cline { 2 - 6 } & Slightly Disagree & 1 & 2.6 & 2.6 & 10.3 \\
\cline { 2 - 6 } & Neutral & 5 & 12.8 & 12.8 & 23.1 \\
\cline { 2 - 6 } & Slightly Agree & 9 & 23.1 & 23.1 & 46.2 \\
\cline { 2 - 6 } & Agree & 10 & 25.6 & 25.6 & 71.8 \\
\cline { 2 - 6 } & Agree Strongly & 11 & 28.2 & 28.2 & 100.0 \\
\cline { 2 - 6 } & Total & 39 & 100.0 & 100.0 & \\
\hline
\end{tabular}

Table 86: Descriptive Statistics: frequencies

\begin{tabular}{|c|c|c|c|c|c|}
\hline \multicolumn{2}{|c|}{} & \multirow{2}{*}{ P3V6 own-idea } & \multicolumn{2}{c|}{$\begin{array}{c}\text { Cumulative } \\
\text { Percent }\end{array}$} \\
\hline \multirow{4}{*}{} & Frequency & Percent & Valid Percent & 2.6 \\
\cline { 2 - 6 } & Disagree Strongly & 1 & 2.6 & 2.6 & 5.1 \\
\cline { 2 - 6 } & Slightly Disagree & 1 & 2.6 & 2.6 & 12.8 \\
\cline { 2 - 6 } & Neutral & 3 & 7.7 & 7.7 & 38.5 \\
\cline { 2 - 6 } & Slightly Agree & 10 & 25.6 & 25.6 & 61.5 \\
\cline { 2 - 6 } & Agree & 9 & 23.1 & 23.1 & 100.0 \\
\cline { 2 - 6 } & Agree Strongly & 15 & 38.5 & 38.5 & \\
\cline { 2 - 6 } & Total & 39 & 100.0 & 100.0 & \\
\hline
\end{tabular}

